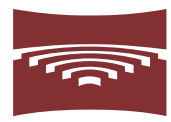

RígAs STRADINA UNIVERSITĀTE
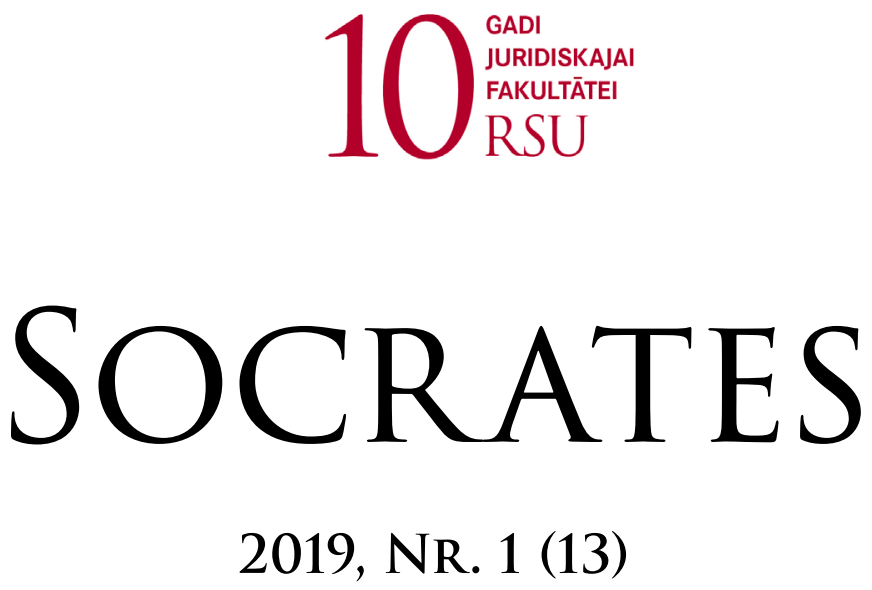

Rīgas Stradina universitātes

Juridiskās fakultātes

elektroniskais juridisko

zinātnisko rakstu žurnāls

Rīga Stradiṇš University

Faculty of Law

Electronic Scientific

Journal of Law

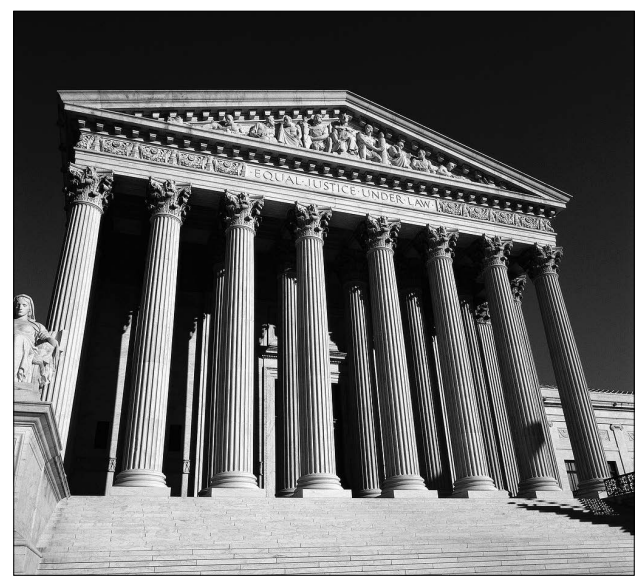

RĪGA • 2019 • RSU 
Socrates: Rīgas Stradiṇa universitātes Juridiskās fakultātes elektroniskais juridisko zinātnisko rakstu žurnāls = Rīga Stradin̦š University Faculty of Law Electronic Scientific Journal of Law. Rīga: RSU, 2019, Nr. 1 (13). 113 lpp. https://doi.org/10.25143/socr.13.2019.1

\section{Redkolēgija / Editorial Board}

Jānis Gardovskis (vadītājs) - Dr. habil. med., profesors, Rīgas Stradiṇa universitāte, Latvija Iveta Ozolanta - Dr. habil. med., profesore, Rīgas Stradina universitāte, Latvija

Andrejs Vilks (atb. zin. redaktors) - Dr. iur., profesors, Rīgas Stradiṇa universitāte, Latvija

Vladimirs Eminovs - Dr. habil. iur., profesors, Maskavas Valsts juridiskā universitāte, Krievija

Osvalds Joksts - Dr. habil. iur., profesors, Rīgas Stradina universitāte, Latvija

Viktors Justickis - Dr. habil. iur., profesors, Viḷnas Mīkola Romera universitāte, Lietuva

Sandra Kaija - Dr. iur., profesore, Rīgas Stradiṇa universitāte, Latvija

Valters Kego (Walter Kego) - Zviedrijas Drošỉbas un politikas attīstības institūts, Zviedrija

Ando Leps - Dr. habil. iur., profesors, EuroAcademy, Igaunija

Jaceks Zeḷinskis (Jacek Zielinski) - Dr. habil. sc. pol., profesors, Siedlces Dabas un humanitāro zinātnuu universitāte, Polija

Alvīds Šakočs (Alvydas Šakočius) - Dr. iur., profesors, Lietuvas Militārā akadēmija, Lietuva

Vitolds Zahars - Dr. iur., profesors, Daugavpils Universitāte, Latvija

Natālija Gutorova (Nataliya O. Gutorova) - Dr. iur., profesore, Poltavas Tiesību institūts, Jaroslava Gudrā Nacionālā juridiskā universitāte, Ukraina

Vitālijs Paškovs (Vitaliy M. Paschkov) - Dr. iur., profesors, Poltavas Tiesību institūts, Jaroslava Gudrā Nacionālā juridiskā universitāte, Ukraina

Redakcijas padome / Editorial Council (Rīgas Stradiṇa universitāte)

Jānis Baumanis - Dr. iur., vadošais pētnieks

Jānis Grasis - Dr. iur., asoc. profesors

Osvalds Joksts - Dr. habil. iur., profesors

Aldis Lieljuksis - Dr. iur., asoc. profesors

Sandra Kaija - Dr. iur., profesore

Uldis Kinis - Dr. iur., asoc. profesors

Andrejs Vilks - Dr. iur., profesors

Tenis Nigulis - Izdevniecības un poligrāfijas nodaḷas vadītājs

Visi žurnālā ievietotie raksti ir recenzēti. / All journal articles are reviewed.

Citējot atsauce uz izdevumu ir obligāta. / Upon citing the journal article, reference to the journal is mandatory.

Autoru viedoklis var nesaskanēt ar redkolēgijas viedokli. / Opinion of authors may not coincide with the editorial views.

Par faktu pareizibu atbild autori. / The authors are held responsible for the truthfulness of the facts.

Redaktori / Editors: Ināra Mikažāne (latviešu val.), Jānis Zeimanis (angḷu val.)

Korektore / Corrector: Inga Lievīte (latviešu val.)

Maketētāja / Layout: Ilze Stikāne

RSU IPD-84/210

(c) Rīgas Stradina universitāte, 2019

Dzirciema iela 16, Rīga, LV-1007

ISSN 2256-0548 


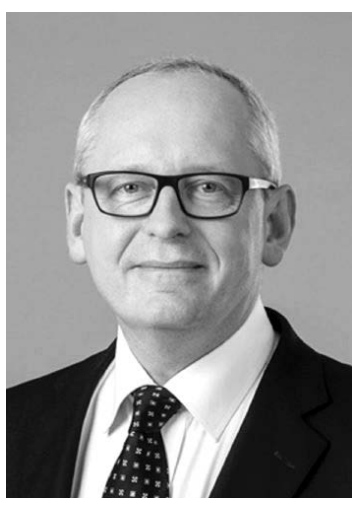

\section{Cienijamie zinātniskā žurnāla "Socrates" lasītāji!}

2019. gada vasarā RSU Juridiskā fakultāte atzīmēja 10 gadu jubileju. Šo desmit gadu laikā fakultāti absolvējuši vairāk nekā 2000 speciālistu tiesību zinātnē. Mēs lepojamies ar fakultātes devumu iekšlietu sistēmas darbinieku sagatavošanā, jo faktiski izpildām savulaik likvidētās Policijas akadēmijas lomu.

Juridiskā fakultāte vienmēr ir bijusi aktīva ne tikai studiju procesā, bet arī pētniecībā, - teju katru gadu tiek izdotas nozīmīgas, starpdisciplināras monogrāfijas, ir arī savs elektroniskais zinātnisko rakstu žurnāls "Socrates", aktīvi tiek aizstāvēti promocijas darbi par valstiski nozīmīgiem tiesiskiem jautājumiem. Tas viss ir sasniegts par spīti tam, ka, līdzīgi kā citās RSU sociālo zinātṇu studiju programmās, RSU nav valsts budžeta vietu.

Mēs ar Juridisko fakultāti saistām lielus plānus - uzskatām, ka arī turpmāk tieši RSU Juridiskā fakultāte var būt piemērota struktūrvienība Valsts policijas darbinieku izglītošanai. Mums jau ir lieliskas iestrādes, kas jāturpina, piemēram, fakultātes vairākus gadus realizētā studiju programma "Policijas darbs". Nākotnē daudz vairāk būtu jāturpina pilnveidot un investēt simulācijās balstītā izglìtībā, kas ir visas RSU prioritāte.

Novēlu Juridiskajai fakultātei un tās mācībspēkiem turpināt sekmīgo attīstības cel̦u! Esmu pārliecināts, ka mūs visus gaida spožas virsotnes!

Rīgas Stradina universitātes rektors profesors Aigars Pētersons 


\section{Dear readers of the scientific journal "Socrates"!}

In summer, 2019, RSU Faculty of Law celebrated its $10^{\text {th }}$ anniversary. Over the tenyear's time, the faculty has been graduated by over 2000 specialists in law sciences. We take pride in the contribution in the preparation of the staff of home affairs, since we perform the functions of the once-dissolved Police Academy.

The Faculty of Law has always been active not only within the study process but also in research - nearly every year important interdisciplinary monographs have been issued, we possess our own scientific journal "Socrates", there is an active process of Doctoral Thesis defence on juridical issues significant nation-wide. This all has been achieved despite the fact that similarly to other RSU social science study programmes, there are no state funded study places.

Grand plans are made in connection with the Faculty of Law - we consider RSU Faculty of Law the place for preparation of the State Police officers. There are effective strategies in place that need to be developed; for example, the study programme "Police Work" realised at the Faculty for a few years now. In the future, greater emphasis should be placed on development and investment in simulation-based education, which is also the priority for the entire university.

I wish the Faculty of Law and its teaching staff to continue the successfully started way towards development. I am certain that significant heights are in front of us.

The Rector of Rīga Stradiņš University

Professor Aigars PẼTERSONS 


\section{Saturs / Contents}

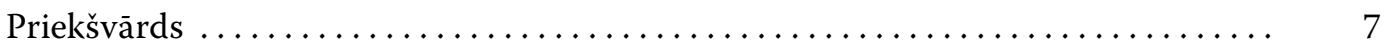

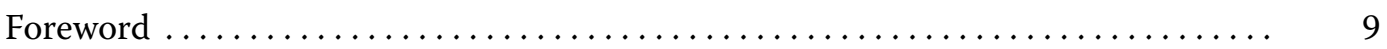

Aleksandrs Matvejevs. Profesionālā ētika un policijas operatīvā darbïba: vai pastāv kompromiss? . ........................... 11

Professional Ethics and Police Investigative Activity:

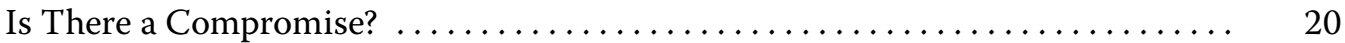

Ilze Bērzina-Ruķere. Uz sabiedrību vērsta policijas darba metodes mūsdienu mainìgajā pasaulē $\ldots \ldots \ldots \ldots \ldots \ldots \ldots \ldots \ldots \ldots \ldots \ldots \ldots \ldots \ldots \ldots, 22$

Modern Methods to Prevent Cybercrime in Latvia $\ldots \ldots \ldots \ldots \ldots \ldots \ldots \ldots .28$

Ériks Trels. Naida noziegumi Latvijā: kriminālatbildība un piemērotie sodi ...... 30

Hate Crime in Latvia: Criminal Liability and Punishment ............. 39

Vladimir Jilkine. Phenomenon of Corruption, Its Origin in the Grand

Duchy of Finland and the Level in Modern Finland ................. 42

Korupcijas fenomens, tā aizsākumi Somijas Lielhercogistē

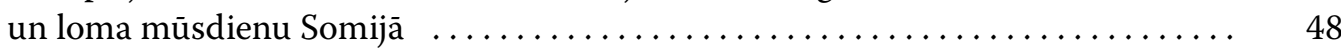

Andrejs Vilks, Aldona Kipāne. Cilvēku tirdzniecība: kriminologiskās problēmas . . 50

Criminological Problems of Human Trafficking $\ldots \ldots \ldots \ldots \ldots \ldots \ldots \ldots . . \ldots 6$

Jel̦ena Alfejeva. Atbildība par nepatiesas informācijas sniegšanu apdrošinātājam apdrošināšanas līguma ietvaros $\ldots \ldots \ldots \ldots \ldots \ldots \ldots \ldots .63$

Responsibility for Providing False Information to Insurance Contract ....... 73

Arta Snipe. Prasijuma tiesību noilgums zemes likumiskajā

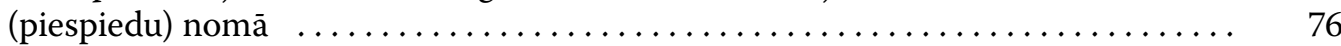

Limitation Period for Claims Arising from Compulsory Land Lease $\ldots . \ldots . \ldots 91$

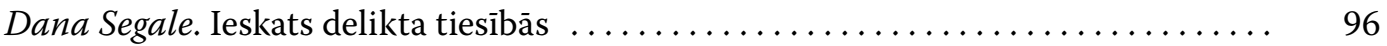

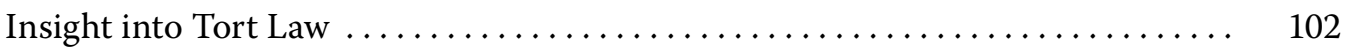


Agnese Reine-Vìtina. Personas datu aizsardzības mērḳis un tiesiskā regulējuma vēsturiskā attīstïba .

Objective of Protection of Personal Data and Historical Development of Legal Framework $\ldots \ldots \ldots \ldots \ldots \ldots \ldots \ldots \ldots \ldots \ldots \ldots \ldots . \ldots \ldots . \ldots \ldots$

Autoru alfabētiskais rādìtājs / Alphabetic List of Authors $\ldots \ldots \ldots \ldots \ldots \ldots . \ldots \quad 110$

Pielikums. RSU Juridiskās fakultātes akadēmiskā personāla sagatavotās un izdotās monogrāfijas (2009-2019) 


\section{Priekšvārds}

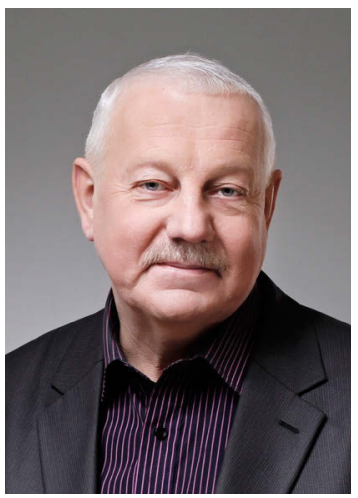

Pie RSU elektroniskā juridiskā žurnāla "Socrates" lasītājiem nonāk Juridiskās fakultātes desmitās jubilejas gada pirmais izdevums. "Socrates" žurnālam tas ir jau 13. izdevums, un tajā tiek pārstāvēts plašs tiesību zinātnes apakšnozaru spektrs, kas laus lasītājiem izvēlēties un iepazìties ar viṇus saistošām problēmām un autoru piedāvātajiem to risinājumiem.

RSU Juridiskajā fakultātē tiek nodrošināta policijas darbinieku izglītošana profesionālajā bakalaura studiju programmā "Policijas darbs". Līdz ar to pilnīgi likumsakarīga ir atsevišḳu autoru pievēršanās policijas darba problēmu izziņai. Dr. iur. A. Matvejevs savā rakstā analizē policijas operatīvo darbu un profesionālo ētiku. Logiski, ka rodas jautājums par to, vai atseviškłas operatīvās darbības (piemēram, operatīvā novērošana) ir ètiskas un morāli atbalstāmas. Autors pamatoti secina, ka tiesību aktā paredzētā operatīvā darbība ir ètiska, jo tiesību akts ir visaugstākais sabiedrības morāles veids. $L L M$ I. Bērziṇa-Ruķere skata problēmu, kas skar mūsdienu noziedzības prevencijas metodes un policijas darbu ar sabiedrību Latvijā. Autore pievērš uzmanību nozīmīgākajiem pārmaiṇu procesiem policijas darba metožu izmaiņām un mēǵinājumiem ieviest jaunas komunikācijas un saskarsmes metodes, lai efektīvāk uzrunātu iedzivotājus. Pēdējie desmit gadi ir bijuši nozīmīgi, veidojot mūsdienīgu policijas dienestu.

Ar policijas darba tematiku ir saistīti raksti, kuri veltīti krimināltiesiskajām problēmām. Tā Dr. iur. Ė. Treḷs ir pievērsies noziegumiem, kuri saistīti ar naida kurināšanu, kad nodarījumu upuri bieži vien neinformē policiju par notikušo, jo viņiem nav pārliecības par tiesībaizsardzības iestāžu vēlmi vai spēju efektīvi izmeklēt šos notikumus. Autors aplūko tiesībsargājošo iestāžu reaǵēšanas praksi, izmeklējot naida kurināšanas noziegumus (2012-2019). Iepazīstoties ar masu mediju publiskoto informāciju, var veidoties pārliecība, ka korupcija ir tikai postpadomju valstu sociāli tiesiska patologija. Dr. iur., $M F A$, V. Žilkina (V. Jilkine) rakstā mēs varēsim pārliecināties, ka korupcijas fenomens nav svešs arī Somijai gan tās lielhercogistes laikā, gan arī mūsdienās. Somijas zinātnieka skatījums uz korupcijas problēmu varētu būt interesants arī mūsu žurnāla lasītājam. Dr. iur. A. Kipāne un priekšvārda autors (A. Vilks - red.) sniedz ieskatu cilvēku tirdzniecības mūsdienu kriminolog̣iskajos aspektos, atzīstot, ka cilvēku tirdzniecība ir dinamiska parādība, kas viegli pielāgojas mainīgiem apstākḷiem. Viens no cilvēku tirdzniecības dzinējspēkiem ir sociālo un ekonomisko procesu globalizācija. 
Tradicionāli lielākā dạ̦a žurnālā ievietoto rakstu attiecas uz civiltiesisko sfēru vai ar to saistìto problemātiku. Tā Dr. iur. J. Alfejeva kā vadošā speciāliste apdrošināšanas tiesỉbu jomā analizē daudzveidīgos atbildības aspektus par nepatiesas informācijas sniegšanu apdrošinātājam apdrošināšanas līguma ietvaros. Interesants ir rakstā aplūkotais jautājums par atbildības noteikšanu un nepatiesas informācijas sniegšanas sekām. Zvērinātā advokāte A. Snipe savā rakstā skata jautājumu par prasījuma tiesībām, kas izriet no zemes likumiskām piespiedu nomas attiecībām un to noilguma. Autore secina, ka prasijuma tiesības par zemes nomas tiesisko attiecību konstatāciju vai nomas līguma noslēgšanu pret personu, kas veic daudzdzīvokḷu ēkas pārvaldī̌anu un apsaimniekošanu, zemes īpašniekam rodas no laika, kad apsaimniekotājs ir pārṇēmis konkrētās ēkas pārvaldī̌nanu, vai no zemes īpašuma tiesību iegūšanas briža. D. Segale sniedz ieskatu delikta tiesību jomā, atklājot šì jēdziena vēsturisko un mūsdienu traktējumu, kā arī analizē nepamatota personas tiesību aizskāruma aizsardzības problemātiku. A. Reine-Vìtiṇa savā rakstā apskata personas datu aizsardzības attīstību un tiesiskā regulējuma vēsturisko evolūciju. Autore kā vienu no būtiskākajām problēmām minētajā aspektā atzīst faktu, ka pieaugoša moderno tehnologiiju izmantošana sekmē informācijas vākšanu par fiziskajām personām, kā arī tiesības uz privātās dzīves neaizskaramības ievērošanu.

RSU Juridiskās fakultātes profesors ANDREJS VILKS 


\section{Foreword}

The first edition of the $10^{\text {th }}$ anniversary year of the RSU electronic legal magazine "Socrates" has reached its readers. The magazine, however, is celebrating its $13^{\text {th }}$ edition, which has included a diverse spectrum of articles representing legal sciences; thus, allowing the readers to choose the most binding problems and learning about their solutions as proposed by the authors.

RSU Faculty of Law ensures training of police officers in the professional bachelor study programme "Police Work". Therefore, it is quite natural that a few authors study the problems of police work. Dr. iur. A. Matvejevs in his article analyses operational work and professional ethics of the police. Obviously, the question arises whether several operational activities (for example, operational observation) are ethical and morally acceptable. The author concludes that statutory operational work is ethical since legal act is perceived as the highest form of public morality. LLM I. Bērzina-Ruksere addresses the problem of current crime prevention methods and police work with the public in Latvia. The author highlights the most significant processes of change - change of methods of police work and trials to implement new methods of communication to more effectively address the population. The last ten years have been important in establishing an up-to-date police service.

Articles dealing with police work are related to those attributed to criminal law issues. Thus, Dr. iur. $\overline{\mathbf{E}}$. Trels has addressed crimes of incitement to hatred, when victims do not inform the police about the abuse since they lack certainty of response practice or ability to investigate the cases by law enforcement agencies. The author analyses response practice investigating crimes of incitement to hatred between 2012 and 2019. Acquainting oneself with the information available in the public domain, one can be convicted that corruption is a socially legal pathology of the post-soviet states. Dr. iur., MFA V. Jilkine has written the article that ensures that corruption phenomenon has not been strange to Finland neither during its Grand Duchy nor nowadays. The viewpoint by the Finnish scientist might excite the readers of our magazine. Dr. iur. A. Kipāne and the author of the foreword $(A$. Vilks - ed.) provide insight into human trafficking in current criminological aspects, admitting that human trafficking is a dynamic phenomenon easily adapting to changing circumstances. One of the driving forces of human trafficking is the globalisation of social and economic processes.

Traditionally the largest part of the articles included in the magazine relate to the civil sphere or related issues. For instance, Dr. iur. J. Alfejeva, the leading specialist in insurance law, analyses diverse aspects of responsibility in provision of faulty information 
to the insurer within the limits of the insurance contract. The topic on determination of responsibility and consequences of providing false information stands out the most. Sworn advocate A. Snipe in her article discusses the issue of the right of claim deriving from the legal forced lease of land and its limitations. The author concludes that the right of claim for the establishment of a legal lease of land or entering into a lease agreement with a person, responsible for the management of the apartment building, occur to the landowner from the time the operator has taken over the management of the specific building or from the moment of acquisition of land ownership. D. Segale provides an insight into a delicate area of justice providing historical and current treatment of the concept; she also analyses the issues of protection of unjustified interference with the rights of a person. A. Reine-Vitina in her article describes development of protection of personal data and the historical evolution of the legal framework. In the given context, the author recognises that technology use by adults enhances information collection on individuals as well as the right to respect for privacy.

Professor at RSU Faculty of Law ANDREJS VILKS 
https://doi.org/10.25143/socr.13.2019.1.011-021

\title{
Profesionālā ètika un policijas operatīvā darbība: vai pastāv kompromiss?
}

\author{
Dr. iur. Aleksandrs Matvejevs \\ Daugavpils Universitāte, Sociālo zinātṇu fakultāte, \\ Tiesību katedra, Latvija \\ aleksandrsmatvejevs5@inbox.lv
}

\section{Kopsavilkums}

Rakstā ir aplūkotas policijas operatīvās darbības morālās un ètiskās problēmas. Pamatojoties uz publikāciju analīzi, kas veltīta morālajiem un ètiskajiem aspektiem, un policijas operatīvās darbības praksi, var secināt, ka pastāv dažādi viedokḷi (arī pretēji) un morāla rakstura spriedumi par jēdzieniem "meli", "maldināšana" un "nodevība".

Ja daži nepietiekami pieredzējuši vai nepietiekami kvalificēti kriminālpolicijas darbinieki reizēm rīkojas neētiski, tas nenozīmē, ka operatīvā darbība ir neētiska un amorāla.

Atbilstīgi formālajai log̣ikai tiesību aktā paredzētā operatīvā darbība ir morāla jau tāpēc vien, ka tiesību akts ir visaugstākais sabiedrības morāles veids.

Svarīgākais secinājums - viedoklis, ka operatīiās darbības pilnībā atbilst morāles principiem un ētikas normām, vērtējams kā pārāk vienkāršota pieeja. Tādēl nepieciešams plašāk izpētīt operatīvās darbības morāles un ētiskos aspektus.

Atslēgvārdi: policijas operatīvās darbības morālie un ētiskie jautājumi, meli, maldināšana, nodevība, cīṇa ar noziedzību.

\section{levads}

Profesionālajai ètikai ir būtiska nozīme daudzās profesijās, to skaitā arī operatīvās darbības subjektu amatpersonu darbībā. Profesionālā ètika ir kriminālpolicijas darbinieku savstarpējo attiecību, kã arī attiecību ar slepenajiem palīgiem un citām personām morāles normu un principu sistēma. Profesionālā ētika ietver vispārējās ētikas normas. Ėtika ir filozofijas nozare - zinātne par morāli un tikumību [5, 283].

İstenojot operatīvās darbības, morālei ir svarīga vieta personu pamattiesību nodrošināšanas sistēmā. Morāle ir cilvēku izturēšanās principi un normas gan attiecībās citam ar citu, gan ar sabiedrību [5, 659]. 
Operatīvo darbību morālo un ētisko pamatu, šo darbību îstenošanas morālo un ètisko attiecību pētī̌sanas aktualitāti noteic daudzu atšķirīgu operatīvās darbības metožu īpatnību pastāvēšana, kas saistītas ar nepieciešamību atklāt sarežğìtus, rūpīgi maskētus noziedzīgus nodarījumus.

Pētijjuma mērḳis ir analizēt operatīvās darbības morālos un ètiskos aspektus, identificēt problēmas un ieteikt to risinājumus.

Pētījuma objekts ir morālās un ètiskās attiecības starp kriminālpolicijas darbiniekiem un slepenajiem palīgiem, starp pašiem darbiniekiem, starp viniiem un citām personām.

Pētījuma materiāls - operatīvās darbības tiesību un morāles normas.

Operatīvās darbības tiesību normu piemērošanas procesā būtiska nozīme var būt morāles normu prasībām. Tiesību normas sekmē morāles normu ievērošanu [7, 23-28]. Operatīvās darbības morāles un ètikas principi, nemot vērā to formulējuma skaidrību un nepārprotamību tiesību aktu normās, nav problēma.

Pētījuma mērḳa sasniegšanai tika izmantotas vairākas zinātniskās pētniecības metodes: tiesību normu interpretācijas metode - sistēmiskā interpretācijas metode, ar kuru tika noskaidrota operatīiās darbības tiesību un morāles normu jēga saistībā ar profesionālās ètikas normām; induktīvā un deduktīvā metode - izdarot slēdzienus par operatīvās darbības morāles principiem un ētikas normām.

Pētījuma teorētiskais pamats galvenokārt ir starptautiskie un nacionālie tiesību akti, kuri regulē operatīvās darbības.

\section{Operatīvās darbības morāles un ētikas pamati}

Tiesību aktos, lai gan tikai vispārīgi, ir reglamentēti operatīvās darbības pasākumu îstenošanas pamatnoteikumi. Proti, operatīvā darbība, ko visbiežāk ìsteno slepeni, tiek izmantota tikai izn,ēmuma gadỉjumos (ja problēmu nevar atrisināt ar publiskiem līdzekḷiem).

Operatīvās darbības uzdevumi ir šādi:

- personu aizsargāšana pret noziedzīgiem apdraudējumiem;

- noziedzīgu nodarījumu prevencija, to novēršana un atklāšana, noziedzīgu nodarïjumu izdarïjušo personu un pierādỉjumu avotu noskaidrošana;

- to personu meklēšana, kuras tiesību akta noteiktajā kārtībā tiek turētas aizdomās, ir apsūdzētas vai notiesātas par noziedzīga nodarījuma izdarǐšanu;

- gan noziedzīgi iegūtas mantas, gan citas mantas (arī finanšu līdzekḷu), kas var tikt pakḷauta arestam saistībā ar noziedzīga nodarījuma izdarīšanu, meklēšana;

- to personu meklēšana, kuras pēkšņi un bez acīmredzama iemesla pametušas savu pastāvīgo vai pagaidu uzturēšanās vietu, neievēro savu ierasto dzīvesveidu un ar kurām sazināšanās nav iespējama, kā arī nepilngadīgo un to personu meklēšana, kuras vecuma, fiziskā, garīgā stāvokḷa vai slimības dẹl ir aprūpējamas un ir aizgājušas no mājām, ārstniecības iestādes vai citas uzturēšanās vietas (t. i., bez vēsts pazudušo personu meklēšana); 
- valsts neatkarības, konstitucionālās iekārtas, teritoriālās integritātes, ekonomiskās suverenitātes, militārā potenciāla, kā arī citu valsts vai sabiedrības drošỉbas apdraudējumu konstatēšana un novēršana;

- valsts noslēpuma aizsardzība;

- informācijas iegūšana par konkrētām personām, ja jālemj jautājums par šo personu pieeju valsts noslēpumam, Ziemel̦atlantijas līguma organizācijas, Eiropas Savienības vai ārvalstu institūciju klasificētajai informācijai vai par personu tiesībām uz tādu nodarbošanos vai amatu, par kuru likumā paredzēta valsts drošības iestāžu vai sabiedriskās kārtības un drošîbas nodrošināšanas iestāžu atzinuma sniegšana;

- tiesību aktā noteiktajos gadījumos - personu speciālās aizsardzības nodrošināšana. Operatīvās darbības pasākumi citu uzdevumu un mērḳu îstenošanai ir aizliegti. [3] Tādējādi atbilstīgi formālajai log̣ikai tiesību aktā paredzētā operatīvā darbība jau ir morāla, jo tiesību akts ir visaugstākais sabiedrības morāles veids.

Vērtējot operatīvo darbību atbilstīgi morāles normām, tādi līdzekḷi kā vardarbība, meli, maldināšana un nodevība ir nepien,emami. Labi zināms, ka, veicot operatīvās darbības, kriminālpolicijas darbinieks kādā veidā izmanto administratīvos piespiedu līdzekḷus vai procesuālo kārtību, maldina personu vai mudina citu personu to darīt. Tādēl rodas vairāki jautājumi: vai izmantotos līdzekḷus var izskaidrot vai pamatot ar ētikas normām, varbūt tie būtu jānoraida kā amorāli? Vai to piemērošana neizkropḷo mērḳa būtību? Šajā gadïjumā viens no galvenajiem noteikumiem, kas nosaka operatīvās darbības morālo pamatu, ir operatīvās darbības mērḳi un to sasniegšanai izmantoto līdzekḷu attiecības.

Vērtējot operatīvās darbības īstenošanas ètiskumu, tā jāuzskata par morālu kompromisu. Attiecībā uz operatīvo darbību jāatzīmē, ka kompromiss, iespējams, ir sarežğítākais morālās izvēles akts. Pastāv liels risks, kas ir ipaši kontrastēts, ja analizē dominējošos motīvus saistībā ar motivācijas sfēru, kurā persona slepeni sadarbojas ar operatīvās darbības subjekta amatpersonu, kas veic operatīvās darbības. Lielākā daḷa šo personu ir sociāli nelabvēlīgā situācijā, to uzvedība neatbilst sabiedrībā vispārpien,emtām normām, bieži vien šiem cilvēkiem ir noziedzīga pagātne un cieša saistība ar noziedzīgo pasauli, kriminogēno vidi u. tml. Tāpēc kriminālpolicijas darbiniekiem bieži vien ir jāatrod kompromiss starp viṇu prātā dominējošajām neiecietības prioritātēm cīṇā ar noziedzību un kriminogēnās vides personu sniegto palīdzību.

Morālais un vērtējošais faktors būtiski mazina aktivitāšu efektivitāti, jo pastāv nesaderība starp cīṇas pret noziedzību ideāliem un faktisko sadarbību ar kriminālās vides pārstāvjiem.

Runājot par operatīvās darbības aktivitāšu zemāko morālās pieḷaujamības robežu un tās kritērijiem, jāṇem vērā, ka, praktiski izstrādājot operatīvās darbības pasākuma uzdevumu, bieži vien vērojama morālo prasību profesionālās pārveidošanas galējā forma to deformācija - un korporatīvās morāles veidošanās pēc profesionālās darbinieku grupas interesēm. L̦oti bieži profesionālās grupas korporatīvās intereses neatbilst sabiedrības, cilvēku grupas vai indivīda interesēm un ir pretrunā ar tām. Šìs parādības neitralizācija 
ir atkarīga no izglītības ietekmes intensitātes un satura, kas vērsts ne tikai uz ideologísko pozīciju veidošanos, bet arī uz noteiktu uzvedības noteikumu izstrādi, risinot operatīvās darbības pasākumu uzdevumus, kuriem loti būtisks ir morālais aspekts. Šie ir daži no vispārīgajiem noteikumiem, kas raksturo operatīvās darbības morāles pamatus.

Personu pamattiesību nodrošināšanas sistēmā, īstenojot operatīvās darbības pasākumus, būtiska loma ir morālei. Tādēl katrā īpašajā situācijā, kas rodas, piemērojot speciālos līdzekḷus noziedzīgu nodarījumu novēršanā un atklāšanā, obligāts ir morālais novērtējums. Morāles šajā sistēmā ir ḷoti svarīga arī tādēḷ, ka tā ietekmē morālo îpašî̉bu attīstîbu kriminālpolicijas darbiniekiem, kuriem jebkurā sarežginitā situācijā, lielākoties nelabvēlīgos apstākḷos, jāvar neitralizēt iespēju rīkoties nepareizi, nostāties pret patiesību un taisnīgumu, personu tiesībām un brīvībām. Citiem vārdiem sakot, morāle ir integrēta kā noteicošais faktors kriminālpolicijas darbinieku tiesību aizsardzībai, izvēloties tās normas, ja nav nepārprotamu juridisku operatīvās darbības vadlīniju.

Operatīvās darbības būtība ir tāda, ka tā neizbēgami ietekmē darbības īstenošanā iesaistìto cilvēku tiesības un brīiības. Tajā pašā laikā gan starptautiskās, gan nacionālās tiesību normas garantē ikvienas personas tiesības uz privātās un gimenes dzìves, dzìvokḷa un korespondences neaizskaramību (Eiropas Cilvēka tiesību un pamatbrīvību aizsardzības konvencijas 8. pants un Latvijas Republikas Satversmes 96. pants). [1]

Tomēr tiesības uz privātās dzives, mājokḷa un korespondences neaizskaramību nav absolūtas. Tās var tikt ierobežotas Eiropas Cilvēka tiesību un pamatbrīvību aizsardzības konvencijas 8. panta otrajā daḷā paredzētajos gadỉjumos, tas ir, ja šis ierobežojums paredzēts likumā un ir nepieciešams demokrātiskā sabiedrībā, lai aizstāvētu valsts drošības, sabiedriskās kārtības vai valsts labklājības intereses, lai nepieḷautu nekārtības vai noziegumus, lai aizsargātu veselību vai morāli vai aizstāvētu citu tiesības un brīvības [1]. Latvijas Republikas Satversmes 116. pantā paredzēts, ka personas tiesības uz privātās dzīves neaizskaramību var ierobežot likumā paredzētajos gadījumos, lai aizsargātu citu cilvēku tiesības, demokrātisko valsts iekārtu, sabiedrības drošỉbu, labklājību un tikumību [2]. Tādēḷ operatīvās darbības veikšana ir jānodrošina ar adekvātu kontroli, kuras gaitā izvērtēe, vai iejaukšanās personas privātajā dzīvē nav patvalīga.

Dažkārt operatīvās darbības pasākumi attiecas uz ievērojamu skaitu personu, kas nav iesaistītas noziedzīgo nodarījumu izdarīšanā. Operatīvās darbības pamatā ir informācijas vākšana, apkopošana, salīdzināšana un izmantošana, kura raksturīga izlūkošanai, kas uz operatīvās darbības prakses apkopojuma un teorijas atziṇu pamata izstrādā operatīvu interesi izraisošu faktu un personu vispārinātu pamatpazīmju kopuma aprakstu - profilu -, ko operatīvās darbības gaitā salīdzina ar daudzu sabiedrībā notiekošu parādību un personu līdzīgām īpašībām, kam bieži vien var nebūt un arī nav saistības ar konkrētiem krimināliem notikumiem. Tikai tad, kad šādas salīdzināšanas rezultātā tiek konstatēta krimināla notikuma vai parādības saistība ar konkrētu personu, likumā noteiktajos gadījumos var rasties pamats kriminālprocesa uzsākšanai un speciālo izmeklēšanas darbību pielietojumam [6]. 
Bieži pret personu gribu vai nejaušìbas dēḷ tām ir jāsaskaras (kopdzīves u. c. apstākḷu dēḷ) ar cilvēkiem, kas izdarījuši prettiesiskas darbības un darbības, kas rada iepriekš minēto apdraudējumu. Tādēl ir nepieciešami piemēroti aizsardzības pasākumi, lai aizsargātu un atjaunotu sabiedrisko attiecību subjektu tiesības un likumīgās intereses, kas izriet no operatīvās darbības pasākumu ieviešanas un turpmākās pilnveidošanas.

\section{Operatīvās darbības juridiskā kultūra}

Juridiskā kultūra ir īpaša sociālā parādība, kas tiek uztverta kā indivīda un sabiedrības kvalitatīvs juridiskais statuss un ir viena no svarīgākajām sastāvdaḷām, kas nosaka sociālo attiecību progresīvu attīstību. Juridiskā kultūra (latīnu val. cultura - kopšana, izglïtība) ir sabiedrības kultūras sastāvdaḷa, kas cieši saistīta ar visas sabiedrības kultūras izaugsmi. Tā ir idejiski tiesisks sabiedrības stāvoklis - izaugsmes līmenis noteiktā tās attīstības posmā.

Juridisko kultūru veido divi elementi:

- intelektuālais moments, kas raksturo tiesību zināšanas un izprašanas pakāpi, jeb informativais elements;

- likumības ievērošanas jeb imperatīvais elements.

Tas nozīmē, ka nepietiek tikai zināt un izprast priekšrakstus un ievērot tiesību normu prasības. Juridiskā kultūra raksturo tiesību un tiesiskās apziṇas attīstības līmeni, personu tiesību un brīvību plašumu un garantētîbu, likumdošanas pilnīgumu un efektivitāti, likumības un tiesiskās kārtības stabilitāti, juridiskās zinātnes un juridiskās izglītîbas līmeni, valsts pārvaldes ierēdṇu un darbinieku morālo līmeni u. c. Tã ir rezumējoša kategorija, sabiedrības tiesiskās attīstības līmeṇa rādītājs, sabiedrības tiesiskās apziṇas spogulis [4, 100-101].

Kriminālpolicijas darbinieku juridiskā kultūra un dziḷas juridisko vērtību zināšanas ir priekšnoteikums attīstītai juridiskajai psiholoǵijai, kas balstās uz dziḷu un stabilu morāles pamatu. Augstāks juridiskās kultūras līmenis un tiesību aktu ievērošana nosaka arī ieradumu pakḷauties tiesību aktu normām: pirmkārt, ieradumu izpildīt šo vai citu juridisko formu; otrkārt, ierastu attieksmi pret juridisko prasību izpildi kopumā.

Operatīvo darbību pasākumu īstenošanas gaitā juridiskā kultūra personas pamattiesības nodrošina nevis tieši, bet netieši, pilnveidojot un intensificējot organizatorisko un juridisko izglīî̉bu. Tikai ar augstu juridisko kultūru tiek sasniegts pietiekami iedarbīgs tiesiskās attiecības noteicošais un individuālais regulējums, notiek efektīva tiesību aktu izmantošana. Juridiskās kultūras izpausme operatīvo darbību pasākumu īstenošanā, lai nodrošinātu personas pamattiesības, ir saistìta ar juridiskās domāšanas līmeni un tiesiskās apziṇas līmeni konkrētā situācijā.

Tiesiskā apziņa ir tiesisko uzskatu, teoriju, ideju un jūtu (tiesisko emociju) kopums, kas izsaka indivīda, sociālo grupu vai tautas attieksmi pret tiesībām un to prasībām, dod tiesisko parādību novērtējumu no likumības un taisnīguma viedokḷa, kā arī pauž jaunas 
nepieciešamās tiesiskās prasības, kas atspoguḷo sabiedrības tālākās ekonomiskās un kultūras attīstības uzdevumus, kā arī atsevišḳu personu vajadzības un intereses [4, 259].

Viens no svarīgākajiem faktoriem, kas noteic profesionālās tiesiskās apzinnas stāvokli, kriminālpolicijas darbiniekiem ir zināšanas un attieksme pret juridiskās kultūras saturu un visiem tās elementiem. Tiesiskā apzinna ir saistîta ar tiesību aktu normu un citu juridisko vērtību piemērošanu un to aizsardzību pret pārkāpumiem, īstenojot operatīvās darbības pasākumus.

Juridiskā kultūra ir iekḷauta tiesību normu struktūrā, un tādējādi ir ietverta mehānismā, kas nodrošina personas pamattiesības.

Šobrīd var identificēt galvenos morālās nestabilitātes aspektus: nepietiekamas morālās pārdomas, kad personīgā morālā atbildība un apņemšanās ir proporcionāla sistēmas stāvoklim; morālās apziṇas un morālās prakses racionalizācijas fenomenu, t. i., formālā log̣ika triumfē pār tādām neracionālām ētikas kategorijām kā gods un lojalitāte, zvērests, pienākums u. c. Maksimālā morāles racionalizācijas pakāpe izpaužas tādās apkaunojošās parādībās kā nodevība un kukuḷošana. Reizēm ne mazāku kaitējumu rada arī nepamatota dedzība un nežèelīgs naidīgums pret personām, kas iesaistītas noziedzīgu nodarījumu izdarīšanā. Kriminālpolicijas darbiniekiem mēdz būt t. s. sargsuṇa sindroms, kas attiecībā uz tiesībpārkāpēju ietver jebkādu līdzekḷu un psihologisko paṇēmienu, līdz pat spīdzināšanai, izmantošanu.

Novērtējot operatīvās darbïbas pasākumu morāli vai specifiskas uzvedības iespējas, var secināt, ka šis novērtējums var būt saistìts ar to, vai šì darbība vai rīcība kḷūs plaši zināma sabiedrībai. Tādēḷ ir jākoncentrējas uz slepenības nodrošināšanas uzlabošanu un sabiedrības informēšanu.

Latvijas Republikas Saeima 1993. gada 16. decembrī pieṇēma Operatīiās darbības likumu [3]. Tas stājās spēkā 1994. gada 13. janvārī un pirmo reizi Latvijas pastāvēšanas vēsturē reglamentēja operatīvo darbību. Atbilstoši Operatīvās darbības likuma 8. panta trešajai dal̦ai operatīvās darbības pasākumu organizācija, metodika un taktika ir valsts noslēpums. Operatīvās darbības pasākumus, kuri daudzus gadus no plašas sabiedrības ir paslēpti aiz slepenības zīmoga, vairums cilvēku uztver kā amorālus. Slepenu iejaukšanos personu privātajā dzīvē sabiedrība neuzskata par pieṇemamu. Operatīvās darbības izpausmes, tās strukturālie elementi (operatīvās darbības pasākumi - operatīvā sarunu noklausīšanās, operatīvā novērošana (izsekošana), operatīvā iekḷuššana u. tml.) nozīmē, ka operatīvā darbība nav morāla šis koncepcijas vispārpieņemtajā nozīmē.

\section{Operatīvās darbības mērḳi}

Šo jautājumu var aplūkot no cita log̣iska pieņēmuma, t. i., ka operatīvā darbība ir morāla un humāna. Svarīgākais ir tas, kādam mērḳim tā kalpo. Mērḳis ir aizsargāt personu: dzīvību un veselību; tiesības un brīvības; godu, cien,u, îpašumu u. c., proti, sabiedrības jeb publiskās intereses. Šis ir operatīvās darbības morālais un dziḷi humānais mērḳis. 
Operatīvās darbības morālo vērtību nosaka mērḳa, līdzekḷu un praktiskā rezultāta morālā nozīme, kas norāda uz to, ka operatīvās darbības tiesībaizsardzības pasākumi, mērḳi un uzdevumi ir piesātināti ar augstu morālo saturu.

Morāle kā noteicošais faktors operatīvās darbības pasākumu tehnologijai ir svarīgāka nekā kriminālprocesam, jo tiesību normu skaits, kurās noteikti morāles principi, operatīvās darbības tiesībās ir ievērojami mazāks nekā kriminālprocesuālajās tiesībās. Turklāt sociālajai kontrolei mazāk pieejama ir operatīvās darbības pasākumu tehnologiija, kas lielākoties sabiedrībai ir paslēpta. No tā secināms, ka bieži operatīvās darbības morāle ir atkarīga no vadītāja attieksmes. Jebkura operatīvās darbības taktiskā lēmuma pieṇemšana ir morālas izvēles situācija. Pareizās morālās vērtības un ideolog̣iskās idejas vadītājam ḷauj saistìt sevi un savu darbību ar visaugstākajām vērtībām un redzēt ne tikai savas darbības originalitāti, bet arī augstā līmenī saskatìt tās prestižu un sabiedrisko nozīmīgumu.

Operatīvās un kriminālprocesa darbības tiek balstītas uz vieniem un tiem pašiem principiem. Gan operatīvās, gan izmeklēšanas darbības ir vērstas uz konstitucionālās sistēmas pamatprincipu aizsardzību - cilvēka tiesību uz dzīvību un brīvu attīstību, tautas suverenitāti, varas dalīšanu, valdības atbildību, tiesu neatkarību, daudzpartiju sistēmu un visu politisko partiju vienlīdzību, tostarp tiesību uz attiecīgajām konstitucionālajām normām, opozīciju un opozīcijas darbības radīšanu. Operatīvās darbības, izmeklēšanas darbības un to rezultāti nedrīkst būt vērsti pret cilvēku, bet tiem jābūt humānistiskiem, jo to mērḳis ir aizsargāt cilvēku augstākās intereses.

Ja operatīvās darbības rezultātu izmantošanu krimināllietās konceptuāli vērtē no pierādijjumu piel̦aujamības viedokḷa, tad redzams, ka tai nav nopietnu šḳēršlı. Atbilstoši to kognitīvajai būtībai un tajos noteiktajai nozīmei, operatīvās darbības pasākumu rezultāti, kā arī pierādījumi parādās kriminālprocesa pierādījumos kā viens no ticamajiem līdzekḷiem pierādījumu priekšmetā ietverto apstākḷu noteikšanai. Nosacỉjumi, lai pierādījumus atzītu par nepieņemamiem, ir tiesībpārkāpumi, kas saistīti ar kriminālprocesa dalībnieku konstitucionālo tiesību un brīvību ierobežošanu, kā arī procesuāliem pārkāpumiem, kas ietekmējuši pierādījumu veidošanas procesu un tādējādi radījuši vai varēja izraisît saṇemtās informācijas zudumu vai sagrozī̌sanu. Konstitucionālais princips par personu pamattiesību ievērošanu ir viens no galvenajiem operatīvās darbības principiem, un tas nozīmē, ka ir jāievēro Latvijas Republikas Satversmes normas, kas ietver starptautiskos standartus cilvēktiesību jomā.

\section{Operatīvās darbības efektivitāte}

Operatīvās darbības efektivitāti, kura pēc sava satura ir sociālā darbỉba, vērtē ar sabiedrības sociālo normu palīdzību. Tieši sociālās normas ir arī vērtējamā subjekta prasību pret saturu, formām un darbības metodēm nodošanas kanāls un funkciju izpildes mērs, kad sistēma sasniedz objektīvo mērḳi. Turklāt sociālās normas savā kopsummā un sakarībā ir vērstas uz tiesiskiem, ètiskiem, psihologiskiem, ekonomiskiem un organizatoriskiem efektivitātes kritērijiem (mērogiem). 
Sociālo normu kā sabiedrisko attiecību dalībnieku darbības un uzvedības mēroga izmantošana pašu normu un to ievērošanas pakāpes vērtēšanai ne vienmēr ir vienkāršs uzdevums.

Tiesību normas ir izteiktas racionāli apzinātos un logiski formulētos noteikumos (aizliegumos un aț̣aujās), kuros līdzekḷi pakḷauti mērḳim, tuvākie mērḳi pakḷauti tālākiem u. tml. Piemēram, kriminālprocesuālo tiesību normās ir formulētas konkrētas prasības un noziedzīgu nodarījumu atklāšanā, kad notiek izmeklěšanas darbības, amatpersonu rīcībai jāatbilst šīm normām. Savukārt Operatīvās darbības likumā vien daḷẹji ir noteikta kārtība, kā jārealizē operatīvās darbības pasākumi. Operatīvās darbības likumā, piemēram, nav noteikts, kā jāveic operatīvā aptauja, operatīvā uzziņa, operatīvā noskaidrošana vai kāds cits operatīvās darbības pasākums. Daḷēji šì kārtība tiek regulēta ar iekšējiem normatīvajiem aktiem, tomēr lielākoties, veicot kaut vai vispārējus pasākumus, kriminālpolicijas darbinieks vadās pēc operatīvās taktikas atziṇām, kuras tiesību aktā nav iespējams regulēt, tādēl šāà gadījumos robežas nosaka vispārīgās likumības prasības un darbinieka morāli ētiskās kvalitātes, kuras tiesību aktos ir nepietiekami atspoguḷotas.

Citi sociālo normu veidi (tikumiskās, morālās, ētiskās) sabiedriskajā apziṇā parasti netiek dalīti atsevišķos elementos. Tie eksistē viengabala tēlu, stereotipu, uzvedības standartu veidā, un cilvēki tos uztver tieši tādus, kādi tie pastāv sabiedrības apziṇā. Bieži vien šāda uztvere apgrūtina to izmantošanu kā operatīvās darbības efektivitātes vērtēšanas kritērijus.

Morāles normas, piemēram, ietver vardarbības nosodījumu, ètiskās normas nodevības, ziṇu pienešanas nosodījumu. Bet kriminālpolicijas darba specifikas dēḷ tās darbinieki ir spiesti izmantot vardarbību (lietot šaujamieročus, fizisku spēku, speciālos līdzekḷus u. c.) un slepenu informācijas avotu palīdzību.

Tādēḷ operatīvās darbības efektivitātes vērtēšana un mērǐšana kā tiesiskuma, ètiskuma u. tml. kritēriju ievērošanas pakāpe ir nopietna teorētiska un praktiska problēma. Efektivitātes vērtēšanas problēmas zinātniski korekts risinājums ir saistīts ar trim raksturīgiem sociālo normu apstākḷiem.

Pirmkārt, sociālo normu hierarhiju un kopsakarību. Tiesības iekḷauj visbūtiskāko no sociālajām normām, noteic atkāpšanās no dažām normām leǵitīmās robežas. Operatīvās darbības likums legalizē, pārvērš operatīvas darbības subjektu amatpersonu rīcību slepenas informācijas iegūšanā par sociāli nozīmīgu. Iekšējie normatīvie akti reglamentē darbības organizāciju, metodes, taktiku, līdzekḷus un uzskaiti, kas nav publiski pieejama un ir slepena.

Operatīvās darbības efektivitātes vērtēšanas objektivitāte bieži ir saistīta ar normatīvo aktu skaidrību un pakāpeniskumu un normatīvi tiesiskās regulēšanas raksturu, saturu, realizācijas formām un metodēm, lai nepiel̦autu operatīvās darbības subjektu amatpersonu patvalı operatīvās darbības pasākumu īstenošanā.

Otrkārt, operatīvās darbības efektivitātes vērtēšana un mērīšana ir saistīta ar uzvedības stereotipiem un standartiem, kas noteikti sociālajās normās un vērtēšanas kategoriju veidā atklājas ne tikai individuālā līmenī, bet arī sabiedriskās apziṇas kā masu parādības 
līmenī. Tieši šis apstāklis veido sabiedrisko domu, kas var tikt izmantota sociālās darbības efektivitātes vērtēšanai.

Sabiedriskās domas objektivitātes un drošỉbas paaugstināšana kā operatīvās darbïbas efektivitātes vērtēšanas kritērijs ir saistīta ar divu uzdevumu risināšanu:

- sabiedriskās domas aktīvu veidošanu stabilu negatīvo stereotipu pārvarēšanai operatīvās darbības uztverē;

- zinātniska korektuma ievērošanu sabiedriskās domas pētīšanā.

Treškārt, jārēḳinās ar to, ka sociālo normu substanci veido sabiedriskās attiecības, tātad sociālo normu ievērošanas pakāpe un mērs atsevišķu personu un sociālo organizāciju darbībā un uzvedībā var tikt ne tikai novērtēti, bet arī pietiekami izmērīti ar kvantitatīvām metodēm.

Efektivitātes vērtēšana un noteikšana jāveic ar kvalitatīvo un kvantitatīvo rādītāju sistēmu, kas raksturo realizācijas ārējās un iekšējās organizatoriskās darbības saturu, formu, metodes un personisko stilu. Par rādītāju avotiem noder sociologiskie, kriminologiskie un citi pētījumi, operatīvās darbības subjektu atskaites, analìtiskie dokumenti, statistikas dati u. c.

\section{Secinājumi}

İpaši jāuzsver vairākas raksturīgas operatīvās darbības iezīmes.

1. Nepieciešamība kriminālpolicijas darbiniekiem iedziḷināties cilvēka iekšējā pasaulē, tieši ietekmēt personu un bieži vien arī viņas likteni. Šì iezīme ir saistìta ar profesionālās morāles normām, kas, no vienas puses, veicina profesionālo funkciju sekmīgu îstenošanu un, no otras puses, nodrošina personas kā operatīvās darbības objekta interešu aizsardzību.

2. Operatīvā darbība nepiellauj standartus, un to nevar pilnībā regulēt ar tiesību aktu normām. Nestandarta situācijas, uz kurām neattiecas kādi norādījumi, kriminālpolicijas darbiniekam problēmu liek radoši risināt. Gan ārējie, gan iekšējie tiesību akti (instrukcijas, pavēles un citi normatīvie akti) diezgan plaši regulē kriminālpolicijas darbinieku darbību, tomēr parasti šì darbība ir saistīta ar riskantām situācijām, kurās amatpersonai jāparāda augsta pienākuma izjūta un morālās īpašības. Ja tiesību akts ir bezspēcīgs vai iezīmē tikai vispārējo pieñemamo uzvedības sistēmu, morāle kḷūst par galveno sociālo regulatoru.

3. Sniedzot kriminālpolicijas darbiniekiem iespēju izmantot īpašus tiesiskos līdzekḷus un metodes profesionālo uzdevumu risināšanai, sabiedrība izvirza augstas prasības, tāpēc viniem jābauda liela sabiedrības uzticība. Šì iezīme izriet no pirmajiem diviem secinājumiem, jo tiesības ietekmēt personu, viṇas likteni, kā arī darbības radošais raksturs, neapšaubāmi, nozīmē lielāku atbildību pret sabiedrību.

4. Operatīvās darbības slepenais raksturs izraisa nepieciešamību to saistīt ar morāles elementiem. Tie ḷauj ierobežot sabiedrības kontroli pār ikdienas 
Aleksandrs Matvejevs. Profesionālā ètika un policijas operatīvā darbība:

vai pastāv kompromiss?

operatīvām darbībām. Sabiedrība parasti sniedz novērtējumu par dažiem operatīvās darbības pasākumu rezultātiem, bet šìs darbības slepenības dēḷ tā nevar novērtēt dažu metožu izmantošanas legiitimitāti. Tāpēc, veicot operatīvo darbību, būtiski jāpalielina sabiedrības un amatpersonu pienākuma apziņas loma un atbildība par savu rīcību. Jāietver arī iespēja personām, kas nav saistītas ar šo darbību, morāli novērtēt operatīvās darbības pasākumus. Praksē konkrētu operatīvo darbību patiesais saturs, tostarp arī to patiesais morālais raksturs, ir jāslēpj. Tāpēc, vērtējot operatīvās darbības morālo saturu, dažreiz to var uztvert kā amorālu.

5. Nepieciešama aktīva sabiedrības domas veidošana, lai operatīvās darbības uztverē pārvarētu stabilus negatīvos stereotipus.

\section{Professional Ethics and Police Investigative Activity: Is There a Compromise?}

\section{Abstract}

The article addresses moral and ethical problems of police investigative activities. Based on analysis of publications devoted to moral and ethical aspects of the legal activity and practice of the police investigation agencies' functioning, the author has concluded that there are opposing views, opinions and moral judgments regarding such concepts as lie, deception, and betrayal.

If some under-experienced or unqualified criminal police officers allow unethical behavior, this does not mean that the investigative activity is unethical and immoral.

The author has concluded that, from a formal logical point of view, the operative action envisaged by the act is already moral, because the act is the highest form of public morality.

Keywords: moral and ethical issues of police investigative activity, lie, deception, betrayal, method of fighting against crime.

\section{Avoti un literatūra}

\section{Tiesību akti}

1. Eiropas Cilvēka tiesību un pamatbrīvïbu aizsardzības konvencija: starptautisks dokuments: pieñemta 04.11.1950. un stājās spēkā 27.06.1997. Latvijas Vēstnesis. 143/144(858/859), 13.06.1997. Iegūts no: https://likumi.lv/ta/lv/starptautiskie-ligumi/id/649 [sk. 20.04.2019.].

2. Latvijas Republikas Satversme: Latvijas valsts likums: pien̦emta 15.02.1922. un stājās spēkā 07.11.1922. Latvijas Vēstnesis. 43, 01.07.1993. Iegūts no: https://likumi.lv/doc.php?id=57980 [sk. 20.04.2019.]. 
Aleksandrs Matvejevs. Profesionālā ētika un policijas operatīvā darbība:

vai pastāv kompromiss?

3. Operatīvās darbības likums: Latvijas Republikas likums: pieṇemts 16.12.1993. un stājās spēkā 13.01.1994. Latvijas Vēstnesis. 131, 30.12.1993. Iegūts no: https://likumi.lv/doc.php?id=57573 [sk. 20.04.2019.].

\section{Literatūra}

4. Juridisko terminu vārdnīca. Rīga: Nordik, 1998.

5. Latviešu valodas vārdnīca. 30000 pamatvārdu un to skaidrojums. Rìga: Avots, 2006.

6. Makans, L. 2006. Procesuālo un operatīvo darbību vienlaicīga pielietojuma problēma konkrētu noziedzīgu nodarījumu atklāšanā un izmeklēšanā. No: Latvijas kriminālprocesa likuma piemērošanas pirmā gada problēmas. Konferences materiālu krājums. Rīga, LPA.

7. Plotnieks, A. 2009. Tiesību teorija \& juridiskā metode. Rīga: SIA “Izglītības soḷi”. 
https://doi.org/10.25143/socr.13.2019.1.022-029

\title{
Uz sabiedrību vērsta policijas darba metodes mūsdienu mainīgajā pasaulē
}

\author{
Mg. iur., LL.M Ilze Bērzina-Rukere \\ Rìgas Stradiṇa universitāte, Juridiskā fakultāte, Latvija \\ propoliceilze@gmail.com
}

\section{Kopsavilkums}

Publikācijā tiek skatītas noziedzības prevencijas mūsdienu metodes un policijas darbs ar sabiedrību Latvijā. Tiek sniegts atskats uz policijas darba metožu nozīmīgākajām pārmaiṇām pēdējā desmitgadē un centieniem ieviest jaunus komunikācijas paṇēmienus, lai efektīvāk uzrunātu iedzīvotājus. Akcentēti veiksmīgākie projekti un iniciatīvas, apliecinot, ka aizvadìtajos desmit gados sperts nozīmīgs solis ceḷa uz mūsdienīgu policijas dienestu: mainìta Valsts policijas darba organizācija un īstenoti daudzi projekti. Taču ikdienā netrūkst piemēru, ka kibernoziegumu un citu noziedzīgo nodarïjumu apkarošanai būs nepieciešams milzum daudz aktivitāšu arī turpmāk. Situācija liek mainīt policijas rīcību un meklēt alternatīvas noziedzības prevencijas metodes.

Atslēgvārdi: uz sabiedrību vērsts policijas darbs, Valsts policija, noziegumu prevencija, kibernoziegumi.

\section{levads}

Šì publikācija sagatavota vēsturiskā brīdī, kad tiek svinēta Rīgas Stradiṇa universitātes Juridiskās fakultātes 10. gadskārta. Aizvadītie desmit gadi īpaši nozīmīgi bija arī Latvijas Valsts policijai, kuru gandrīz pilnībā skāra pārmaiṇu procesi. Nedaudz pakavēšos pie zīmīgākajiem pieturpunktiem šajā laikposmā un atziṇām par pozitīvajām tendencēm, mainot policijas darbu uz sabiedrībai tuvāku un saprotamāku. Pievērsǐšos jautājumiem par Valsts policijas komunikāciju noziedzības prevencijas nolūkā, lai apkarotu pieaugošo noziedzību arī interneta vidē.

${ }^{1}$ LL.M (Legum Magister) - akadēmiskais tiesību zinātṇu maǵistra grāds, kas iegūts ārzemēs. 
Pārmaiṇu gadi un krīze, kas sākās 2008. gadā un nesa izaicinājumus visām Iekšlietu ministrijas struktūrvienībām, radīja gan zaudējumus, gan iespējas. Šoreiz varbūt mazāk par skumjajiem notikumiem un to sekām, ${ }^{2}$ bet vairāk par iespējām un izaicinājumiem, kas valsts iestādēm, īpaši Valsts policijai, lika pozitīvi mainīties - vairāk meklēt atbalstu un pievērsties sadarbībai, saskarsmi veidot jau uz citiem principiem un ar jaunām, nedaudz aizmirstām, kā arī alternatīvām policijas preventīvā darba metodēm.

Pārskatot policijas darba funkcijas un finanšu resursu izlietošanu, daudz pamatotu jautājumu radās arī par to, kā sabiedrība vērtē policijas darbu un resursu patēriṇa lietderību. Kas ir svarīgi iedzīvotājiem un kas - pašai Valsts policijai? Valsts policijas darbinieki vēlas saṇemt novērtējumu par smago darbu, ko veic, riskējot ar dzīvību un veselību, turpretī iedzīvotāji grib saprast un redzēt, ka policija strādā viṇu interesēs, viṇu apkaimē, ka tā ir pieejama. Tieši pieejamība, saprotama komunikācija un drošības sajūta mūsdienās ir un būs svarīga iedzīvotājiem [9, 16-38]. İpaši nozīmīgi tas ir steidzīgā dzīves ritma dēḷ. Daudzi cilvēki nelasa drukātos preses izdevumus, neskatās televīzijas pārraides un jaunumus uzzina tikai no virsrakstiem interneta vietnēs vai no sociālajiem tīkliem. Policijas vērtējums rodas no izpratnes un informācijas pieejamības par to, ko īsti policija dara katra iedzīvotāja labā. Tas tika visnotal pierādìts Talsu pilotprojektā [10], un kopš 2009. gada Valsts policijā tiek veiktas sociolog̣iskās aptaujas par iedzīvotāju uzticēšanos Valsts policijai. Jaunākie dati rāda, ka Valsts policijai uzticas $70 \%$ iedzīvotāju [23]. Ar jaunu pieeju un koncepciju darbam pēc projekta beigām un pēc Valsts policijas attīstības koncepcijas izstrādes 2013. gada nogalē izveidots Valsts policijas Prevencijas vadības birojs, kuram tika uzdots jaunās metodes ieviest dzīvē. Prevencijas darbs šobrīd ir ietverts visos Valsts policijas svarīgākajos plānošanas dokumentos [4]. Valsts policijas Prevencijas stratēgijā 2018.-2020. gadam, piemēram, ir iekḷauta ideja par iecirkṇu prevencijas plānu izstrādi un vides dizainu kā modernu metodi noziedzības mazināšanai. ${ }^{3}$

Mūsdienu steidzīgajā laikā aizvien svarīgāka kḷust policijas pieejamība, policija kā pakalpojumu sniedzēja cietušajiem [8] un sabiedrībai un saprotama komunikācija ar šo institūciju. Šo plānu sekmīga îstenošana dzìvē ir atkarīga no liela skaita policijas darbinieku, kam vajadzīgas nepieciešamās iemaņas un entuziasms, lai mainītu pieeju darbam. Nenoliedzami, jāturpina uzlabot arī policijas darba vērtēšanas kritēriji. Par tiem jau sen tiek runāts, bet sistēmas pārkārtošana norit diezgan lēni, jo nepieciešamais dažādu dokumentu noformēšanas apjoms palicis visai nemainīgs. Protams, svarīgi, ka plānošanas dokumentos iedzīvināta ideja par policijas darbu, kas vērsts uz sabiedrību, un pamazām ikdienas darba organizācijā izmaiṇas notiek, un pat tiesas atsaucas uz šo pieeju. Piemēram, Administratīvās rajona tiesas spriedumā par Rìgas pašvaldības policijas darbu un uzlikto sodu iedzīvotājam norādìts, ka "policijas uzdevums vispirmām

2 Latvijas Policijas akadēmijas likvidācija ir unikāls notikums ES dalībvalstī. Akadēmija tika likvidēta ar LR iekšlietu ministres Lindas Mūrnieces rīkojumu 2009. gada 25. maijā.

3 Valsts policijas prevencijas stratēgiskie darba virzieni 2018.-2020. gadam: Valsts policijas dokuments. Nav publicēts. 
Ilze Bērziņa-Ruḳere. Uz sabiedrību vērsta policijas darba

metodes mūsdienu mainīgajā pasaulē

kārtām nav represīva darbība un pārkāpēju sodīšana, bet gan likumpārkāpumu novēršana un atvērta sabiedriskā sevisa nodrošināšana. Ar policijas vērtību sistēmu mūsdienīgā izpratnē galvenokārt ir saistītas community policing jeb uz sabiedrību vērsta policijas darba idejas" [3].

Kopš 2013. gada Valsts policijā vairāk tiek domāts par dažādām, citādām un modernām policijas prevencijas un komunikācijas metodēm, kuras ìstenojot, piemēram, tiek uzturēta gan Valsts policijas mājaslapa [17], kā arī izveidota ìpaša mājaslapa Mana drošǐba [18], gan arī policijai ir savs konts Twitter, Facebook, Instagram, Draugiem.lv un Youtube. Tos Valsts policijas Sabiedrisko attiecību nodaļa izveidoja 2011. gadā. Pirms tam bija tikai veiksmīga sadarbība ar visiem šo sociālo tīklu uzturētājiem, bet Valsts policijai savu sociālo kontu nebija.

L,oti veiksmīgs bija viens no pirmajiem sadarbības pasākumiem, kas notika Eiropas Komisijas (EK) atbalstītajā projektā "Tu lieto narkotikas, narkotikas lieto tevi!”. Aktivitātes būtība bija šāda: gadījumā, ja jaunietis bija atbildējis, ka pamēgināt narkotikas ir forši, viṇa sociālo kontu policija "arestēja" līdz brīdim, kad meitene vai puisis iepazinās ar Valsts policijas mājaslapā publiskoto informāciju par narkotiku ietekmi uz veselību un juridisko atbildību. [13]

Valsts policija piedalās arī visos lielākajos mūzikas festivālos un ikgadējā sarunu festivālā LAMPA Cēsu pils parkā [22]. Tajos pulcējas ne tikai nevalstisko organizāciju un biznesa pārstāvji, bet arī valsts pārvaldes darbinieki, kuri arī izmanto modernos un atraktīvos saziņas paṇēmienus, lai kḷūtu tuvāki iedzivotājiem un skaidrotu arī aktuālās drošības tēmas.

Valsts policija 2018. gadā festivālā $L A M P A$ pārsteidza klausītājus ar interesantām diskusijām un uzstāšanās veidu. Policijas eksperti uzrunāja dalībniekus par vairākām aktualitātēm, arī par kibernoziegumu prevenciju un apkarošanu. Sarunā viṇi iesaistīja savus sadarbības partnerus - Drošāka interneta centru un sociālo tīklu guru Artūru Medni. Diskusijas laikā dalībniekiem tika dota iespēja uzzināt, ko par viṇiem var atrast sociālajos tīklos, brīvi meklējot informāciju. Ar informācijas meklēšanu gan nodarbojās profesionāli policijas darbinieki, bet tikai likuma atḷautajās robežās ${ }^{4}$ ar internetā brīvi pieejamiem līdzekḷiem. Organizējot pasākumu, tika gādāts, lai katru brīvprātīgo iepazīstinātu ar viņa tiesībām atteikties no informācijas publiskošanas, ja dalībnieks nevēlas, lai eksperimenta rezultātus uzzina plašs klausītāju loks. Cilvēku interese par šo nestandarta pieeju bija negaidīti liela, pat tik liela, ka dažiem interesentiem vajadzēja atteikt. Kāds ir secinājums? Cilvēkus piesaista iespēja satikt policijas darbiniekus neierastā vidē un neierastos apstākḷ̆os. Policija iedzīvotājiem var ne tikai dāvināt suvenīrus, bet arī dalīties ar savām zināšanām. Tas tiek augstu novērtēts, un tādējādi tiek celts policijas prestižs.

${ }^{4}$ Neilgi pirms pasākuma norises spēkā stājās Eiropas Parlamenta un Padomes Regula (ES) 2016/679 par fizisku personu aizsardzību attiecībā uz personas datu apstrādi un šādu datu brīvu apriti un ar ko atceḷ Direktīvu 95/46/EK (Vispārīgā datu aizsardzības regula) par to, ka publiskajos un citos pasākumos dati tiek izmantoti tikai ar datu subjekta piekrišanu. 
Ĺoti veiksmīgs solis saziṇā ar iedzīvotājiem ir Valsts policijas mobilās aplikācijas Mana drošǐba $a^{5}$ izveide 2016. gada nogalē [18]. Pirmo reizi iedzīvotāji ar aplikācijas starpniecību varēja ziṇot par cel̦u satiksmes negadījumiem, nosūtīt attēlus un pildīt drošības testus. İpaša uzmanība, izstrādājot aplikāciju, tika pievērsta drošîbai, policijas un ārkārtas dienestu izsaukšanai un iespējai nosūtìt koordinātes palīdzības dienestiem. Aplikācija izpelnījās lielu sabiedrības interesi un atbalstu [19]. Tà tika uzlabota 2018. gadā, kad aplikāciju papildināja sadal̦a par drošību interneta vidē. Iedzīvotājiem šobrīd ir iespēja nosūtìt ekrānuzṇēmumus, ziņot par kibernoziegumiem un sazināties ar palīdzības sniedzējiem, izmantojot mobilo tālruni vai rakstot e-pastu [21]. Šāda iespēja ir tikai dažās ES dalībvalstīs, un Valsts policijas iniciatīva vērtējama loti pozitīvi. Iedzīvotāji to loti plaši izmanto, viṇi labprāt fotografē dažādus notikumus un situācijas, kas varētu radìt nepieciešamību vērsties policijā pēc palīdzības.

Pieaugošie riski saistībā ar kibernoziegumu izplatīšanos nav mìts, un policijai tie nav vienaldzīgi, tomēr ne visos gadījumos izdodas apsteigt noziedzniekus. Saskaṇā ar Eiropola datiem palielinās dažāda veida krāpšanu, bankas datu viltošanas vai nelikumīgas izmantošanas, dažādu ḷaunatūru un izspiedējvīrusu gadījumu skaits [5]. Eiropas Savienības dalībvalstīs lielākajā dạ̦ā policijas dienestu diemžēl ir tikai viena vai dažas sevišķās nodal̦as, kas specializējušās kibernoziegumu atklāšanā, bet internetā izdarīto pārkāpumu skaits pieaug [14]. Respektīvi, gandrīz visos noziedzīgajos nodarījumos ir pierādījumi, kas saistīti ar moderno tehnolog̣iju izmantošanu, - dati tālruṇos, datoros un planšetdatoros. Informāciju, ko agrāk noziedznieki meklēja "uz ielas", tagad viṇi atrod internetā un rīkojas - sameklē ziṇas par potenciālo interneta krāpniecības vai cita noziedzīgā nodarījuma upuri, nodibina kontaktus un iegūst citus nepieciešamos datus [6].

Tādēl arī nepieciešama policijas dienestu restrukturizācija un policijas darbinieku nepārtraukta izglïtošana un zināšanu papildināšana. Valsts policijai 2017. gadā tika piešḳirti papildu līdzekḷi, valsts finansējums tika palielināts vēl par 500000 eiro, lai iegādātos tehniku un stiprinātu cilvēkresursus, kā arī tika uzsākts līdz šim vērienīgākais Iekšējās drošības fonda (IDF) projekts par kibernoziedzỉbas prevenciju un apkarošanu [16; 17]. Tieši projekta gaitā bija jāatrisina viens no lielākajiem pastāvīgajiem izaicinājumiem iedzīvotāju proaktīva informēšana par kibernoziedzības riskiem. Lai gan tradicionāli policija iedzīvotājus informē jau gadiem ilgi, sadzirdēta tā tiek visai reti. Tādēḷ bija nepieciešams izdomāt, kā pievērst iedzīvotāju uzmanību, kādas atraktīvas, modernas metodes izraudzìties. Par šā EK līdzfinansētā projekta kampaṇas “Nedalies ar svešinieku!" sākumu kḷuva sociālie eksperimenti interneta vietnē Youtube un sociālajā vietnē Facebook. Proti, tika izdomāts Imanta Hakerovska tēls, kas "ierakstīja" savu video emuāru par iedzīvotāju kiberkrāpšanas aktuālajiem veidiem. Tēlā iejutās aktieris, un tika īpaši izdomāts viṇa stils un pielāgota valoda. Izplatot šo video Youtube, tas nekavējoties kḷuva populārs un tika

${ }^{5}$ Valsts policijas mobilo aplikāciju Mana drošỉba iespējams lejupielādēt bez maksas Google Play Shop un App Apple Store. 
gan skatīts, gan pārsūtīts. Pozitīvā un reizē kampaṇai arī ne tik iepriecinošā ziṇa bija tā, ka Imanta Hakerovska uzstāšanās drīz vien tika nobloḳēta, jo saturēja informāciju, kas uzskatāma par nevēlamu, un šāda rīcība liecina par to, ka arī sociālo tīklu saturs tiek uzraudzìts. Protams, kampaṇas īstenotājiem būtu interesantāk, ja tēla popularitāte un video pārpublicēšana turpinātos... Tomēr jāpiemin, ka šis video pavisam ìsā laikā tika pārpublicēts vairākas reizes.

Otrs kampaṇas eksperiments notika sociālajā vietnē Facebook. Kampañai “Nedalies ar svešinieku!" speciāli tika radīts Janas Silas tēls. İpaši tika piedomāts un strādāts, izraugoties tēla fotogrāfijas, stāstot par interesēm un sniedzot citas profilam raksturīgas norādes (par radiem, draugiem, kā arī attēli no ceḷojumiem). Rezultāts diezgan stipri pārsteidza ne tikai Valsts policijas darbiniekus, bet arī sadarbỉbas partnerus - 1600 draugu lıti îsā laikposmā (no 20.08.2018. līdz 16.10.2018.). Izbrīnīja, ka draudzības uzaicinājumi tika apstiprināti nudien ḷoti ātri, un tikai dažkārt kāds iedomājās pajautāt, vai Janu Silu pazīst arī dzīvē. Tieši vīrieši bija tie, kas gandrīz nekad nepainteresējās, vai skaistā meitene ir satikta arī reālajā pasaulē. Šì ir tipiska prakse un raksturīga kḷūda. Diemžēl citos gadījumos, kas nav sociālie eksperimenti, tā bieži noved pie tā, ka cilvēks kḷūst par cietušo kibernoziegumā [7], apstiprināja kibernoziedzības apkarošanas eksperts Dmitrijs Homenko. ${ }^{6}$ Kampañas rezultāti iedzīvotājiem ir pieejami arī tiešsaistē Delfi vietnē [20]. Bez pavisam vienkāršiem draudzības uzaicinājumiem un apstiprinājumiem Jana Sila saṇēma arī diezgan daudz aizdomīgu vēstuḷu ar draudzības un tikšanās uzaicinājumiem reālajā dzīvē. Tā kā kampaņas mērkis aprobežojās tikai ar profila izveidi un draudzības apstiprinājumiem, rakstītājiem atbildes netika sniegtas, lai gan šādas provokācijas rezultāts varētu būt visnotal interesants, jo Jana no potenciālajiem interesentiem saṇēma 150 vēstules.

Vēl viena aktivitāte, kas notika šajā projektā, bija sociālais eksperiments sadarbībā ar televīzijas raidījumu Bez tabu. Ideja bija šāda: piedāvāt bezmaksas kafiju pret iespēju saṇemt personas datus klientu datubāzei. Piedāvājumam piekrita visai daudz jauniešu un cita vecuma cilvēku, kas pat nepajautāja anketas aizpildīšanas iemeslu. Vienlaikus informācija tika ievadīta interneta vidē, un, pasniedzot kafiju, pašam personas datu îpašniekam tika pastāstīts neliels stāsts par atrasto. Tas lika aizdomāties par iedzīvotāju atlaižu karšu aizpildīšanas paradumiem lielveikalos, kā arī par to, kādus datus par sevi internetā publiskojam paši [11]. Lai gan raidījumā paustais vēstijjums nebija īpaši jauns, tas ieguva lielu popularitāti un par policijas ieteikumiem lika aizdomāties pavisam citādā aspektā.

Datu drošība un tās saistība ar iespējamiem cilvēktiesību pārkāpumiem kḷūst par jaunu mācību priekšmetu daudzās Eiropas Savienības dalībvalstīs. Latvijā problēma ir šāda: ar nevalstisko organizāciju starpniecību, kas bieži vien jau sniedz palīdzību cietušajiem, par šiem jautājumiem sākotnēji tiek runāts kā par kaut ko īpašu, lai gan ārvalstīs tie jau kḷuvuši par pilnībā integrēta interneta drošības un personas datu aizsardzỉbas mācību kursa dạ̣u pamatskolā. Šo ceḷu sākušas iet daudzas Eiropas Savienības dalībvalstis.

${ }^{6}$ Dmitrijs Homenko - Valsts policijas Galvenās kriminālpolicijas pārvaldes Ekonomisko noziegumu apkarošanas pārvaldes 3 . nodaḷas cīnai ar kibernoziedzību priekšnieks. 
Vispārējs kurss par personisko datu aizsardzību un uzvedību internetā izstrādāts arī Eiropas Savienības līmenī, un tajā piedāvātas visdažādākās interesantu diskusiju idejas, un tās mijas ar praktiskām nodarbībām par datu aizsardzības un drošības tēmu: tiesībām uz savas informācijas aizsardzību, labošanu un nepārpublicēšanu, tiesībām sūdzēties. Šajā procesā iesaistās dažādas vietējās tiesību aizsardzības institūcijas, policija, izglìtības iestādes un personas datu aizsardzības ombudi [12].

Latvijā, îstenojot dažādus prevencijas sadarbības projektus kiberdrošības jomā, jau ilgstoši uzticams Valsts policijas sadarbības partneris ir Informācijas tehnologiiju drošības incidentu novēršanas institūcija CERT.LV un Drošāka interneta centrs, kas ne tikai piedāvā mūsdienīgu mājaslapu ar palīdzības iespējām sociālo tīklu kontu lietotājiem [15], bet arī vada praktiskas mācības pedagogiem un vecākiem, piemēram, par drošības uzstādījumiem tālruniem. Drošāka interneta centra eksperti palīdz tiem iedzīvotājiem, kas, izmantojot Valsts policijas mobilo aplikāciju Mana drošỉba, ziṇo Valsts policijai par pārkāpumiem interneta vidē. Mūsdienās aktīvi tiek izmantots arī cietušo uzticības tālrunis 116111, kas arī ir viens no pēdējo gadu laikā īstenotiem veiksmīgākajiem starpdisciplinārajiem prevencijas pasākumiem.

Plašu sabiedrības rezonansi nesen ieguva Augstākās tiesas spriedums jautājumā par to, vai drīkst vai nedrīkst filmēt policijas darbiniekus un bez saskaņošanas publiskot šos attēlus un video sociālajos tīklos. Augstākā tiesa nolēma, ka arī uz Valsts policijas darbiniekiem attiecas Personas datu aizsardzïbas regula [1], proti, bez piekrišanas attēlus izplatìt nedrīkst, un arī valsts dienesta darbiniekiem jānodrošina noteikts privātās dzīves aizsardzības līmenis - tiesības kontrolēt sava attēla izmantošanu [2]. Valsts policijā par šiem jautājumiem līdzīga diskusija bija jau 2010. gadā, kad Talsu policijas iecirkṇa darbinieki publiskoja savas fotogrāfijas pašvaldības mājaslapā, lai iedzīvotāji vinus varētu atpazìt. Tas izraisīja diskusiju pārējo novadu policijas darbinieku vidū, jo ne visi piekrita, ka viṇu fotogrāfijas tiktu ievietotas internetā. Visasāk uz šo ideju reagèja Rīgas regiona policijas darbinieki, kas vismazāk vēlējās tikt publiskoti. Jāpiebilst, ka Rīgas reg̣ionā tradicionāli ir arī viszemākā iecirkṇa inspektoru atpazīstamība - viṇus atpazīst tikai 5-10\% iedzīvotāju.

\section{Secinājumi}

Personas datu aizsardzība un kiberdrošība noteikti ir un arī turpmāk būs viens no policijas darba, kas vērsts uz sabiedrību, izaicinājumiem saistībā ar Valsts policijas prevencijas darbu. Pēdējos gados paveikts ir ḷoti daudz, bet ceḷ̆š, pa kuru jāvirzās policijai, vienmēr būs jāturpina atbilstīgi sabiedrības mainīgajām prasībām un mūsdienu tehnologijām. Svarīgs šajā virzībā ir vadības atbalsts un stratēgiskā plānošana, kurai jāturpina iedzīvināt uz sabiedrību vērsta policijas darba metodes. Vienlaikus var secināt, ka mūsdienīgu policijas darba un prevencijas metožu piemērošana ikdienas dzīvē ir atkarīga no pašiem policijas darbiniekiem un darba vērtēšanas kritērijiem, jo sekmīgi paveikts tiek tas, ko arī novērtē un par ko tiek maksāts. 
Ilze Bērziņa-Rukere. Uz sabiedrību vērsta policijas darba metodes mūsdienu mainīgajā pasaulē

\section{Modern Methods to Prevent Cybercrime in Latvia}

\section{Abstract}

Article is devoted to the topic of community policing and modern crime prevention methods in Latvia. The author is reviewing the last 10 years of work of the Latvian state police to reach a wider public about the different issues of crime prevention, including prevention and implementation of different organisational reforms, including new approaches of modern communication to tackle cybercrime. Analysis about the most challenging initiatives and projects proves that the State police has achieved considerable development in order to become a modern police service. Meanwhile, the author is acknowledging that continuous efforts and initiatives should be made to prevent and fight cybercrimes and other forms of crimes.

Keywords: community policing, State police of Latvia, crime prevention, cybercrime.

\section{Avoti un literatūra}

\section{Tiesību akti}

1. Eiropas Parlamenta un Padomes Regula (ES) 2016/679 par fizisku personu aizsardzïbu attiecībā uz personas datu apstrādi un šādu datu brīvu apriti un ar ko atceḷ Direktīvu 95/46/EK. Eiropas Savienïbas Oficiālais Vēstnesis. L 119/1, 04.05.2016. Iegūts no: https://eur-lex.europa.eu/legalcontent/LV/TXT/?uri=CELEX\%3A32016R0679 [sk. 07.06. 2019.].

\section{Tiesu prakse}

2. Augstākās tiesas 2019. gada 15. marta spriedums lietā Nr. A42050223 SKA-6/2019.

3. Administratīiās rajona tiesas Rīgas tiesu nama 2012. gada 28. decembra spriedums administrativajā lietā Nr. 142173111 (1-0913-12/26).

\section{Literatūra}

4. Iekšlietu ministrijas darbības stratēgiija. Latvijas Republikas Iekšlietu ministrija. 2018. Iegūts no: http://www.iem.gov.lv/files/text/STRATEGIJA__2019v2.pdf [sk. 04.07.2019.].

5. Internet organised crime threat assessment 2018. Europol. Iegūts no: https://www.europol. europa.eu/internet-organised-crime-threat-assessment-2018 [sk. 07.06.2019.].

6. Intervija ar Dmitriju Homenko par drošỉbu interneta vidē: LTV “Rìta Panorāma”. 17.10.2018. Youtube. Iegūts no: https://www.google.com/search?q=INTERVIJA+AR+dMITRIJU+HOMEN KO\&tbm=isch\&source $=$ iu\&ict $x=1 \&$ fir $=$ di0Zi60e3_kcQM\%253A\%252CD19NSQR4f $x 45$ cM\%25 2C_\&vet=1\&usg=AI4_-kTLKmTjot5xtbBBCg5DdEEzsWKnsA\&sa=X\&ved=2ahUKEwjDx9aF 7JvjAhWStYsKHYxzCA8Q9QEwDHoECAUQBA\#imgrc=di0Zi60e3_kcQM: [sk. 08.08.2019.].

7. Intervija ar Dmitriju Homenko par drošỉbu interneta vidē. LTV.LV 18.10.2018. Iegūts no: https:// ltv.lsm.lv/lv/raksts/18.10.2018-intervija-ar-dmitriju-homenko-par-drosibu-interneta-vide. id141979/ [sk. 08.08.2019.].

8. Landmane, D., Rinkevics, A. 2013. Pētījums: Policijas darba kvalitāte cietušā vērtējumā. Rīga. 
9. Ozolina, Ž. 2012. Cilvēkdrošība: Vai iespējams visaptverošs definējums? No: Cilvēkdrošỉba Latvijā un pasaulē: No idejas lìdz praksei. Aut. kol. Ž. Ozoliṇas red. Rīga: Zinātne. 16.-38. lpp. 10. Uz sabiedrību vērsts policijas darbs Latvijā 2009.-2012. gads. Pieredze un nākamie soḷi. Aut. kol. I. Bērziṇa-Ruḳere, I. Avota, N. Grūbis, M. Tošovskis. Rīga: Valsts policija, 2012.

11. Runce, B. 06.11.2018. "Mēs tev uzsauksim kafiju, bet tu pasaki, kā tevi sauc!": "Bez Tabu" eksperimentā atklāj, cik svešiniekam viegli piekḷūt tavai privātajai informācijai! SKATIES.LV Iegūts no: https://skaties.lv/beztabu/nejedzibas/mes-tev-uzsauksim-kafiju-bet-tu-pasaki-ka-tevi-saucbez-tabu-eksperimenta-atklaj-cik-svesiniekam-viegli-pieklut-tavai-privatajai-informacijai/ [sk. 07.08.2019.].

12. The European Handbook for Teaching Privacy and Data Protection at Schools. Fuster, G. G., Kloza, D. (eds). Brussels, 2016.

13. Valsts policija uzsāk sociālo pretnarkotiku kampaṇu jauniešiem "Tu lieto narkotikas, narkotikas lieto tevi”. Latvijas Republikas Iekšlietu ministrija. 31.08.2010. Iegūts no: http://www.iem.gov. lv/lat/aktualitates/jaunumi/?doc=18998 [sk. 07.08.2019.].

14. Valsts policijas 2018. gada pārskats. Latvijas Valsts policija. Iegūts no: http://www.vp.gov.lv/faili/ jauna_mape/vp_2018._gada_parskats.pdf [sk. 07.06.2019.].

\section{Interneta resursi}

15. Drossinternets.lv [Latvijas Drošāka interneta centra mājaslapa]. Iegūts no: https://drossinternets. $\mathrm{lv} /$ [sk. 04.07.2019.].

16. Latvijas Republikas Iekšlietu ministrija [mājaslapa]. Iegūts no: www.iem.gov.lv [sk. 04.07.2019.].

17. Latvijas Valsts policija [mājaslapa]. Iegūts no: www.vp.gov.lv [sk. 08.08.2019.].

18. Mana drošỉba [Valsts policijas Prevencijas vadības biroja izveidota mājaslapa]. 2019. Iegūts no: www.manadrosiba.lv [sk. 08.08.2019.].

19. Mobilajā lietotnē "Mana drošība" būs iespējams ziṇot par savu atrašanās vietu. TV NET.LV 29.11.2016. Iegūts no: https://www.tvnet.lv/4611710/mobilaja-lietotne-mana-drosiba-bus-iespejams-zinot-par-savu-atrasanas-vietu [sk. 04.07.2019.].

20. Nedalies ar svešinieku! Delfi. Iegūts no: https://www.delfi.lv/news/nedalies-ar-svesinieku/ [sk. 07.08.2019.].

21. Policija radījusi jaunu lietotnes rīku drošībai internetā. $L A . L V$ [ziṇu portāls Latvijai]. 07.03.2018. Iegūts no: http://www.la.lv/policija-radijusi-jaunu-lietotnes-riku-drosibai-interneta [sk. 04.07.2019.].

22. Sarunu festivāls LAMPA [mājaslapa]. Iegūts no: www.festivalslampa.lv [sk. 31.05.2019.].

23. Zvirbulis, G. 13.03.2019. Aptauja: Policijai uzticas aizvien vairāk. LSM.LV https://www.lsm.lv/ raksts/zinas/latvija/aptauja-policijai-uzticas-aizvien-vairak.a312614/ [sk. 31.05.2019.]. 
https://doi.org/10.25143/socr.13.2019.1.030-041

\title{
Naida noziegumi Latvijā: kriminālatbildība un piemērotie sodi
}

\author{
Dr. iur. Ëriks Trel̦s \\ Rìgas Stradiṇa universitāte, Juridiskā fakultāte, Latvija \\ eriks.trels@gmail.com
}

\section{Kopsavilkums}

2019. gada 5. martā Eiropas Komisija pret rasismu un neiecietību (The European Commission against Racism and Intolerance, ECRI) publicēja Piekto ziņojumu par Latviju. Tajā, atsaucoties uz Tiesībsarga biroja un nevalstisko organizāciju sniegto informāciju, norādīts, ka naida kurināšanas upuri bieži vien neinformē policiju par notikušo, jo viniem nav pārliecības par tiesībaizsardzības iestāžu vēlmi vai spēju efektīvi izmeklēt šos notikumus, tādēḷ tiek rekomendēts Valsts policijai izveidot speciālu struktūrvienību darbam ar mazāk aizsargātajām sabiedrības grupām. Iepriekšējā ziṇojumā, kas tika publicēts 2012. gada 21. februārī, ECRI norādīja, ka par šāda veida noziegumiem piespriestie sodi (ar dažiem izṇēmumiem, kad tika piemēroti sodi, kas saistīti ar brīvības atṇemšanu) Latvijā ir pārāk saudzīgi.

Rakstā tiek skaidrots, kā šajā jomā mainījusies situācija pēc ECRI Ceturtā ziṇojuma publicēšanas.

Atslēgvārdi: naida noziegumi; naida runa; nacionālā, etniskā, rasu, reliğiskā vai sociālā naida izraisī̌̌ana.

\section{levads}

Naida noziegumu izplatīšanās un cīṇa ar tiem nezaudē savu aktualitāti kā Latvijas Republikā, tā arī citur pasaulē. Apvienoto Nāciju Organizācijas (ANO) Rasu diskriminācijas izskaušanas komitejas (The Committee on the Elimination of Racial Discrimination, CERD) 2018. gada 30. augustā publicētajos noslēguma secinājumos par ANO Konvencijas par visu veidu rasu diskriminācijas izskaušanu [1] izpildi Latvijas Republikas teritorijā tika atzīmēti Latvijas sasniegumi cīṇā ar naida noziegumiem (angḷu val. hate crime) [8]. Atzinīgi novērtējot paveikto, tika arī norādīts, ka komitejai uztraukumu rada neliels reǵistrēto naida noziegumu skaits. Šis jautājums ir aktuāls arī reǵionālā līmenī. Pie līdzīgiem 
secinājumiem savā 2019. gada 5. marta ziṇojumā nonāca Eiropas Komisija pret rasismu un neiecietību [10]. Atsaucoties uz Tiesībsarga biroja un nevalstisko organizāciju sniegto informāciju, ECRI Piektajā ziṇojumā par Latviju norāda, ka naida kurināšanas upuri bieži vien neinformē policiju par notikušo, jo viṇiem nav pārliecības par tiesībaizsardzības iestāžu vēlmi vai spēju efektīvi izmeklēt šos notikumus, kā arī ECRI rekomendē Valsts policijai izveidot speciālu struktūrvienību darbam ar mazāk aizsargātajām sabiedrības grupām.

Latvijas Republikas Tiesībsarga biroja 2016. gada pētījumā "Naida runas un naida noziegumu atpazišanas un izmeklēšanas prakses problēmaspekti Latvijas Republikā" norādìts, ka gadījumā, kad nepieciešams identificēt, vai konkrētais noziedzīgais nodarījums ir "naida noziegums" Latvijas normatīvā regulējuma izpratnē, "nepieciešams konstatēt divus kritērijus: (a) noziedzīgā nodarījuma sastāvs ir iekḷauts Krimināllikumā; (b) noziedzīgā nodarỉjumā ir konstatējams naida motīvs pret konkrētu aizsargājamo sabiedrības grupu" [25, 9]. Vienlaikus pētījumā minēts, ka "Krimināllikuma normās ir noteikta atbildība par naida noziegumu, naida runas un diskriminācijas aizlieguma pārkāpšanas gadỉjumiem, paredzot kriminālatbildību par nacionālā, etniskā un rasu naida izraisǐšanu (Krimināllikuma 78. pants), diskriminācijas aizlieguma pārkāpšanu (Krimināllikuma 149. ${ }^{1}$ pants), kā arī sociālā naida un nesaticības izraisīšanu (Krimināllikuma 150. pants)" [25, 5].

Valsts policijas 2017. gadā izstrādātajās "Vadlīnijās "naida noziegumu" identifikācijai un izmeklēšanai" ir teikts, ka parasti jēdzienu "naida noziegums" saprot kā noziedzīgu nodarïjumu, kas paredzēts Krimināllikuma 71. pantā (Genocīds), 71. ${ }^{1}$ pantā (Aicinājums uz genocīdu), 78. pantā (Nacionāla, etniska un rasu naida izraisīšana), 149. ${ }^{1}$ pantā (Diskriminācijas aizlieguma pārkāpšana), 150. pantā (Sociālā naida un nesaticības izraisiš̌ana), un jebkuru citu noziedzīgu nodarījumu, kurš izdarīts rasistisku, nacionālu, etnisku vai religisku motīvu dēḷ (Krimināllikuma 48. panta pirmās dalas 14. punkts) [31,3].

Latvijas Republikas Augstākās tiesas 2018. gadā publicētajā tiesu prakses apkopojumā "Naida runa un vārda brīvība. Tiesu prakse krimināllietās par Krimināllikuma 74. ${ }^{1}$, 78., 150. pantu. 2012. gada oktobris - 2018. gada maijs" jēdziens "naida noziegums" tiek attiecināts uz nosaukumā minētajiem pantiem. Apkopojuma autori norāda, ka aplūkotajā periodā "stājies spēkā viens spriedums, kurā skatìts jautājums par reliǵiska naida motīvu kā atbildību pastiprinošu apstākli, tāpēc apkopojumā iekḷauts apskats par Krimināllikuma 48. panta pirmās dạ̦as 14. punkta piemērošanu (rasistisks motīvs kā atbildību pastiprinošs apstāklis). Apkopojumā apskatāmajā periodā Tiesu informācijas sistēmā (TIS) nav konstatēti spēkā stājušies spriedumi par noziedzīgiem nodarỉjumiem, kas paredzēti Krimināllikuma $71 .{ }^{1}$ pantā (Aicinājums uz genocīdu) un $149 .{ }^{1}$ pantā (Diskriminācijas aizlieguma pārkāpšana), tāpēc apkopojumā nav iekḷauts šo pantu plašāks apskats" [3, 4].

Jāpiebilst, ka "klasiskā" Austrumeiropas izpratnē jēdziens "naida noziegums" biežāk tiek attiecināts uz nacionālā, etniskā, rasu, religiskā vai sociālā naida izraisiš̌anu (Krimināllikuma 78. un 150. pants), tādēl šajā pētījumā uzmanība pievērsta minētajos pantos paredzētajai atbildībai un piemērotajiem sodiem par tajos paredzētajām darbībām.

Darba mērḳis -, analizējot par naida noziegumiem piemērotos sodus, konstatēt iespējamus problēmjautājumus un piedāvāt to risinājumus. 
Materiāls un metodes - temata analīze tiek veikta, izmantojot vispārīgās pētniecības metodes, piemēram, salīdzināšanu un apkopojumu, cēloṇsakarību atklāšanu, analīzi un sintēzi, statistisko analīzi un iegūtās informācijas matemātisko apkopošanu, kā arī tiesību normu interpretācijas metodes.

\section{Naida nozieguma un naida runas jēdziens un izpratne}

Pirmo reizi jēdziens "naida noziegumi" (hate crime) izmantots 1985. gadā, kad Džons Konjērs (John Conyers), Barbara Keneli (Barbara Kennelly) un Mario Bjadži (Mario Biaggi) publicēja grāmatu "Hate Crime Statistics Act" [13]. Mūsdienās Eiropas Drošības un sadarbības organizācijas jeb EDSO (Organization for Security and Co-operation in Europe, OSCE) Demokrātisko institūciju un cilvēktiesību birojs (Office for Democratic Institutions and Human Rights, ODIHR) piedāvā šādu "naida nozieguma" definīciju:

- jebkurš noziedzīgs nodarījums, tostarp noziegums pret personu vai ìpašumu, kad cietušais, vieta vai nozieguma mērḳis ir izvēlēti pēc to faktiskās vai šḳietamās saiknes, atbalsta, piederības vai dalības grupā, kas definēta "b" dal̦ā;

- grupa var balstīties uz tās locekḷu reālu vai škietamu rasi, nacionālo vai etnisko izcelsmi, valodu, ādas krāsu, religíiu, dzimumu, vecumu, fizisko vai garīgo invaliditāti, seksuālo orientāciju vai citu līdzīgu pazīmi $[12,11]$.

Rīgas Stradiṇa universitātes Juridiskās fakultātes vadošais pētnieks Jānis Baumanis norāda, ka "naids ir cilvēka jūtu izpausmes veids, kas ir vērsts pret noteikto objektu (personu, personu grupu, procesu, parādību), kuram raksturīgs l̦aunums, nelabvēlïba un kas ir noturīgs, ar lielu intensitāti un destruktivitāti" [7, 15]. Jēdziens "naids" tiek skaidrots arī kā "intensīvā nepatika" [32, 112]. Lat viešu literārās valodas vārdnīcā" vārdam "naids" sniegti vairāki skaidrojumi: "(1) dziḷas un noturīgas jūtas, kam ir raksturīga nelabvēlīga, nosodoša, arī kaujinieciska attieksme (parasti pret cilvēkiem, parādībām sabiedrībā); (2) kildas, nesaskaṇas, arī nesaticība" [23, 316-317].

Krimināllikuma komentāros "naids tiek raksturots kā jūtas, kurām raksturīgs l̦aunums, intensīva nepatika, naidīgums, nelabvēlība (pret kādu), savukārt neiecietība tiek definēta kā nepamatoti negatīva attieksme pret cilvēkiem, viṇu dzivesveidu, uzskatiem, jūtām, paražām" $[19,45]$.

Iepriekšèjā Krimināllikuma komentāru redakcijā tika skaidroti jēdzieni "nacionāls", "etnisks" un "rase":

"Nacionāls - tāds, kas attiecas uz nāciju, tautību, tautu, tām raksturīgo sabiedrisko un politisko dzīvi, interesēm; etnisks - saistīts ar izcelsmi, piederību pie kādas tautas (etnosa), saistīts ar kādu tautu (etnosu); rase - vēsturiski izveidojusies liela cilvēku kopība, kam ir kopēja izcelšanās un kopīgas raksturīgas iedzimtas ārējās fiziskās pazīmes, piemēram, ādas, acu, matu krāsa, galvas forma, augums u. c." [20, 44].

Arī "Latviešu literārās valodas vārdnīcā" rodami šie jēdzieni. Vārds "nacionāls" ir "saistīts ar nāciju, tautu, tām raksturīgs" [23, 312]. Savukārt vārdam "nacionalitāte" 
ir vairāki skaidrojumi: "(1) tautîba, tauta; (2) piederība pie kādas nācijas" [23, 311]. Vārds "etnisks" ir "saistīts ar piederību pie kādas tautas; saistīts ar kādu tautu" [22, 514]. Vārds "rase" tiek skaidrots kā "vēsturiski izveidojusies areāla cilvēku grupa, kurai ir kopēja izcelšanās un noteiktās teritoriālās robežās variējošas kopīgas iedzimtas morfolog̣iskās un fiziskās pazīmes (piemēram, ādas, acu un matu krāsa, galvas forma)" [24, 539].

Jāpiebilst, ka

\begin{abstract}
"katrā valstī pastāv arī sava, bieži vien atšḳirīga, jēdzienu izpratne. Piemēram, jēdziena "nacionalitāte" (angḷu val. nationality) vai "nacionālā izcelsme" izpratne Austrumeiropā un Rietumeiropā joprojām atšḳiras. Ja Rietumeiropā ar personas "nacionalitāti” vai "nacionālo izcelsmi" saprot tās valstisku piederību un pat pilsonību (angḷu val. nationals of the State, or citizens of a State), tad Austrumeiropā (arī Latvijā) ar šo terminu apzīmē piederību konkrētai tautībai neatkarīgi no pilsonības" [30, 16].
\end{abstract}

Par cietušo no "naida nozieguma" var būt kā viena, tā arī vairākas personas vai personu grupa, kas ir apvienota ar kādu no šeit minētajām pazīmēm. Pārkāpējs ar nodomu (latīnu val. animus injuriandi) izvēlas šìs personas, balstoties uz kādu no minētām pazīmēm. Lìdz ar to tikai motīvs - naids vai aizspriedumi - atšķir "naida noziegumus" no citiem noziedzīgu nodarījumu veidiem [12, 16-17].

Profesors Uldis Krastiņš pilnīgi pamatoti uzskata, ka motīvs un mērḳis ietekmē nodoma rašanos, tā virzỉbu uz mērḳi un nodoma īstenošanos [18, 108-109]. Motīvs tiek definēts kā iekšējais pamudinājums, dziṇa un tieksme, kas virza vainīgā gribu uz noziedzīga nodarījuma izdarīšanu. "Latviešu literārās valodas vārdnīcā" tiek piedāvāts šāds skaidrojums vārdam "motīvs": "tas, kas rosina, pamudina (uz kādu darbību, rīcību); tas, kas izraisa (kādu darbību, rīcību)" [23, 272]. Savukārt mērkis ir iecerētais rezultāts, ko persona, izdarot noziedzīgu nodarījumu, vēlas sasniegt. Arī "Latviešu literārās valodas vārdnīcā" atrodam līdzīgu skaidrojumu: "tas, ko vēlas, cenšas īstenot, sasniegt; arī nolūks" [23, 165]. Profesors Uldis Krastiņš apgalvo, ka Krimināllikumā bieži vien noziedzīga nodarījuma sastāvs konstruēts tādā veidā, ka panta dispozīcijā nav ỉpaši norādīts uz motīvu vai mērḳi kā obligātu nodarỉjuma sastāva subjektīvās puses pazīmi, taču, lai konstatētu attiecīgā noziedzīgā nodarījuma sastāvu, motīvs un mērḳis ir obligāti jāpierāda [18, 108-109].

Minot "naida noziegumu" izdarīšanas motivāciju kā vienu no šo noziegumu īpatnībām, eksperts "naida noziegumu" jomā no Lielbritānijas Pols Iganskijs (Paul Iganski) norāda arī uz otru "naida noziegumu" atškirību no pārējiem kriminālnoziegumiem, t. i., sekām, ko tie rada [15, 3].

"Naida noziegumi" tiek izdarīti ar nolūku iebiedēt gan konkrēto upuri, gan visu kopienu, kurai tas pieder. Tādējādi notikušā kaitīgās sekas attiecas ne tikai uz konkrētā noziedzīgā nodarỉjuma upuri, bet arī uz attiecībām starp dažādām kopienām, pie kurām pieder uzbrucējs un upuris. Notikušã sekas ir daudz dziḷākas par fizisku nodarījumu vai finansiāliem zaudējumiem, jo tās ietekmē sabiedrību, izraisot bailes, naidu un aizspriedumus $[26,10]$. Kā rāda prakse, "naida noziegumi" atstāj nopietnas sekas gan uz upuri, gan uz kopienu, kurai cietušais pieder, gan arī uz plašāku sabiedrību [9]. 
Jau iepriekšējos pētījumos tika secināts, ka "naida noziegumi" var izpausties fiziska aizskāruma (vardarbības) veidā, verbāla aizskāruma veidā (mutvārdos un rakstveidā) un citā naida izpausmes veidā, piemēram, tīši iznīcinot un bojājot mantu - izsitot logus, pārdurot automašīnas riepas u. tml. [30, 29-68]. Atšḳirībā no fiziskā aizskāruma (vardarbības), verbālais aizskārums (tas var būt izdarīts gan mutvārdos, gan rakstveidā) var aizskart daudz plašāku personu loku. Verbālais aizskārums bieži vien, īpaši angḷu valodā rakstitos pētijumos, tiek saukts par "naida runu" (hate speech).

Eiropas Padomes Ministru komitejas (Council of Europe Committee of Ministers) 1997. gada 30. oktobra Rekomendācijā Nr. (97) 20 sniegts šāds jēdziena "naida runa" skaidrojums: "naida runa" pārklāj visas izteiksmes formas, kas izplata, mudina, veicina vai attaisno rasistisku naidu, ksenofobiju, antisemìtismu vai citas naida formas, kas balstitas uz neiecietību, iekḷaujot neiecietỉbu, kas nāk no agresīva nacionālisma, etnocentrisma, diskriminācijas un naida pret minoritātēm, migrantiem un ārvalstu izcelsmes cilvēkiem [27]. No minētā izriet, ka "naida runa" ir "naida noziegumu" paveids.

Rìgas Stradiṇa universitātes asociētais profesors un viens no autoritātēm kibernoziegumu jautājumos Uldis Ķinis uzskata, ka "(1) naida runa - rasu naida kurināšana, homofobijas, genocīda, kara noziegumu, terorisma propaganda; (2) bērnu pornogrāfija, narkotiku izplatīšana, cilvēktirdzniecība" [17,38] ir tā saucamie satura noziegumi (angḷu val. content crimes), kas izpaužas nelikumīgas informācijas izplatīšanā, izmantojot automatizētu datu apstrādes sistēmu. Papildus minētajam viṇš, atsaucoties uz Annas Vēberes (Anna Weber) pētijumu, norāda, ka naida runu var iedalït šādi: "(1) kūdǐšana uz rasu naidu; (2) kūdīšana uz naidu relig̣isku apsvērumu dēḷ; (3) naida runas izpausmes kā nacionālisms un etnocentrisms; (4) homofobija - naida runa, kas vērsta pret homoseksuāịiem" [17, 47]. Minētais l̦auj secināt, ka naida runai ir dažādas izpausmes un to var iedalìt vairākos veidos.

\section{Normatīvā regulējuma piemērošanas problēmjautājumi}

Jēdzieni "naida noziegumi" un "naida runa" Latvijā nav normatīvi nostiprināti. Kā jau bija minēts šā raksta ievadā, "klasiskā" Austrumeiropas izpratnē jēdziens "naida noziegums" biežāk tiek attiecināts uz nacionālā, etniskā, rasu vai reliğiskā naida izraisišanu.

Krimināllikuma 78. pantā (Nacionālā, etniskā un rasu naida izraisiš̌ana) noteikts:

“(1) Par darbību, kas vērsta uz nacionālā, etniskā, rasu vai reliǵiskā naida vai nesaticības izraisīšanu, - soda ar brīvības atņemšanu uz laiku līdz trim gadiem vai ar īslaicīgu brīvības atṇemšanu, vai ar piespiedu darbu, vai ar naudas sodu. (2) Par tādu pašu darbību, ja to izdarījusi personu grupa vai valsts amatpersona, vai uzñēmuma (uzn,ēmējsabiedrības) vai organizācijas atbildīgs darbinieks vai ja tā izdarīta, izmantojot automatizētu datu apstrādes sistēmu, - soda ar brīvības atņemšanu uz laiku līdz pieciem gadiem vai ar īslaicīgu brīvības atñemšanu, vai ar piespiedu darbu, vai ar naudas sodu. (3) Par šã panta pirmajā daḷā paredzēto darbību, ja tā saistīta ar vardarbību vai draudiem vai ja to izdarījusi organizēta grupa, - soda ar brīvības atṇemšanu uz laiku līdz desmit gadiem un ar probācijas uzraudzību uz laiku līdz trim gadiem vai bez tās." [2] 
Latvijā 2014. gada 25. septembrī Krimināllikumā tika veikti grozījumi, kas pilnveidoja normatīvo regulējumu saistībā ar "naida noziegumiem", Krimināllikuma 150. pantā paredzot atbildību par sociālā naida un nesaticības izraisǐšanu.

Spēkā esošajā redakcijā Krimināllikuma 150. pantā noteikts:

“(1) Par darbību, kas vērsta uz naida vai nesaticības izraisīšanu atkarībā no personas dzimuma, vecuma, invaliditātes vai jebkuru citu pazīmju dēḷ, ja ar to radìts būtisks kaitējums, - soda ar brīvības atṇemšanu uz laiku līdz vienam gadam vai ar īslaicīgu brīvības atṇemšanu, vai ar piespiedu darbu, vai ar naudas sodu. (2) Par šā panta pirmajā daḷā paredzēto noziedzīgo nodarījumu, ja to izdarījusi valsts amatpersona vai uzṇēmuma (uzṇēmējsabiedrības) vai organizācijas atbildīgs darbinieks, vai personu grupa vai ja tas izdarīts, izmantojot automatizētu datu apstrādes sistēmu, - soda ar brīvības atṇemšanu uz laiku līdz trim gadiem vai ar îslaicīgu brīvības atṇemšanu, vai ar piespiedu darbu, vai ar naudas sodu. (3) Par šā panta pirmajā daḷā paredzēto darbību, ja tā saistīta ar vardarbību vai draudiem, vai par šā panta pirmajā daḷā paredzēto noziedzīgo nodarījumu, ja to izdarījusi organizēta grupa, - soda ar brīvības atṇemšanu uz laiku līdz četriem gadiem vai ar ìslaicīgu brīvības atṇemšanu, vai ar piespiedu darbu, vai ar naudas sodu." [2]

Latvijas Cilvēktiesību centra uzdevumā piedalījos tiesnešu, prokuroru, advokātu un policijas darbinieku aptaujās, kas tika rīkotas projektā "Cīnoties ar naida noziegumiem. Labo prakšu identificēšana krimināllikumu piemērošanas un notiesāšanas nosacījumiem attiecībā uz naida motivētiem noziegumiem Eiropas Savienībā". Projekta laikā iegūtā informācija, secinājumi un priekšlikumi tika publicēti brošūrā "Naida noziegumi: prakse un problēmas". Šajā pētījumā tika identificēti vairāki problēmjautājumi, kas saistīti ar "naida noziegumiem" un Latvijas normatīvā regulējuma piemērošanu [16, 58-64].

Projekta laikā tika secināts, ka Latvijas Republikas teritorijā naida noziegumi galvenokārt izpaužas naida runas veidā, ievietojot aizvainojošus komentārus un publikācijas internetā, t. i., izmantojot automatizētu datu apstrādes sistēmu, lai veiktu darbïbas, kas vērstas uz nacionālā, etniskā, rasu vai reliǵiskā naida vai nesaticības izraisīšanu. Papildus minētajam tika konstatēts, ka "lietās par naida izraisišanu, izmantojot automatizētu datu apstrādes sistēmu, tiesas piemēroja sodus, kas nav saistīti ar reālu brīvības atṇemšanu, bet paredz brīvības atṇemšanu nosacìti, ar pārbaudes laiku. Pēdējo gadu laikā novērojama tendence, ka prokuratūra noslēdz ar apsūdzēto personu vienošanos par tai piemērojamo sodu, kas, neapšaubāmi, atvieglo tiesas darbu" [16, 61]. Tomēr

"lielākā daḷa aptaujāto tiesnešu, prokuroru, zvērināto advokātu un Valsts policijas darbinieku pozitīivi vērtē tiesas piemērotos sodus. Viṇi uzskata, ka spēkā esošais normatīvais regulējums ir pietiekami efektīvs, nodrošinot, ka naida noziegumu izdarītāji tiek notiesāti par viṇu veiktajiem noziedzīgajiem nodarījumiem" [16, 61].

Jāpiebilst, ka līdz 2014. gada 28. oktobrim Krimināllikuma 78. panta otrajā daḷā bija reglamentēts, ka darbība, kas apzināti vērsta uz nacionālā, etniskā vai rasu naida vai nesaticības izraisǐšanu, ja tā izdarīta, izmantojot automatizētu datu apstrādes sistēmu, bija uzskatāma par sevišḳi smagu noziegumu, un tika paredzēta brīvības atṇemšana uz 
laiku līdz desmit gadiem. Pašreiz spēkā esošajā redakcijā minētā darbība tiek uzskatīta par smagu noziegumu, tāpēc paredzēta brīvības atṇemšana uz laiku līdz pieciem gadiem. Latvijas Cilvēktiesību centra veiktajā pētījumā vairāki aptaujātie norādīja uz problēmu, kas saistita ar to, ka

\begin{abstract}
"spēkā esošais normatīvais regulējums paredz dažādus sodus par nacionālā, etniskā, rasu un religiskā naida izraisīšanu (Krimināllikuma 78. pants) un par sociālā naida un nesaticības izraisīšanu (Krimināllikuma 150. pants). Atšḳīrās arī šo noziedzīgu nodarījumu institucionālā piekritība. Krimināllikuma 78. pants ir ietverts IX nodaḷā (Noziegumi pret cilvēci, mieru, kara noziegumi, genocīds), kas ir Drošības policijas (no 2019. gada 1. janvāra - Valsts drošības dienesta) piekritībā. Savukārt Krimināllikuma 150. pants ir ietverts XIV nodaḷā (Noziedzīgi nodarījumi pret personas pamattiesībām un pamatbrīvībām), kas ir Valsts policijas kompetencē. Aptaujātie piedāvāja vairākus risinājumus. Pēc viṇu domām, būtu lietderīgi veikt grozījumus Krimināllikumā un paredzētās soda sankcijas par sociālā naida un nesaticības izraisǐšanu (Krimināllikuma 150. pants) pielīdzināt sankcijām, kas paredzētas par nacionālā, etniskā un rasu naida izraisīšanu (Krimināllikuma 78. pants). Otrs risinājums būtu apvienot abus pantus vienā, iekḷaujot jaunizveidoto pantu Krimināllikuma X nodaḷā (Noziegumi pret valsti) vai kādā citā nodaḷā pēc likumdevēja ieskatiem.” [16, 63].
\end{abstract}

Minētās problēmas jau iepriekš biju identificējis un piedāvājis tām iespējamus risinājumus savos rakstos "Teksta juridiskās ekspertīzes īpašỉbas lietās par naida izraisī̌̌anu" $[29,53]$ un "Kriminālatbildība par religíiskā naida vai nesaticības izraisǐšanu" [28, 16-17], kas tika publicēti Rīgas Stradiṇa universitātes Juridiskās fakultātes elektroniskajā juridisko zinātnisko rakstu žurnālā "Socrates".

\title{
Attīstības dinamika un perspektīvas
}

Iekšlietu ministrijas Informācijas centra dati liecina, ka pēdējo piecu gadu laikā (no 2014. gada 1. janvāra līdz 2019. gada 1. janvārim) pēc Krimināllikuma 78. panta tika uzsākti 32 kriminālprocesi (2014. gadā - astoṇi, 2015. gadā - desmit, 2016. gadā - seši, 2017. gadā - viens, 2018. gadā - septiṇi) un pēc Krimināllikuma 150. panta - astoṇi kriminālprocesi (2015. gadā - viens, 2016. gadā - pieci, 2017. gadā - divi) [21].

Salīdzinājumam - citos Krimināllikuma pantos, kuros paredzētā darbība bieži vien izpaužas aicinājumu formā, minētajā laikposmā uzsākto kriminālprocesu skaits bija krietni mazāks. Piemēram, pēc Krimināllikuma $74 .{ }^{1}$ panta (Genocīda, nozieguma pret cilvēci, nozieguma pret mieru un kara nozieguma attaisnošana) tika uzsākti trīs kriminālprocesi (2014. gadā - viens, 2018. gadā - divi) un pēc Krimināllikuma 77. panta (Aicinājums uz agresīvu karu) tika uzsākti divi kriminālprocesi (2014. gadā - viens, 2018. gadā - viens). Lìdz 2018. gada 23. maijam, kad Krimināllikums tika papildināts ar jaunu (IX ${ }^{1}$ ) nodalı (Noziegumi, kas saistiti ar terorismu), $88 .{ }^{2}$ pants (Aicinājums uz terorismu un terorisma draudi) praksē tika lietots sešas reizes (2011. gadā - vienu, 2012. gadā - vienu, 2014. gadā - divas, 2015. gadā - vienu, 2016. gadā - vienu). Savukārt jaunais Krimināllikuma pants $-79 .{ }^{6}$ pants (Terorisma attaisnošana, aicinājums uz 
terorismu un terorisma draudi) - no 2018. gada 23. maija līdz 2019. gada 1. janvārim praksē lietots netika. Papildus jānorāda, ka nekad netika piemērots praksē Krimināllikuma 71. ${ }^{1}$ pants (Aicinājums uz genocīdu), Krimināllikuma 81. pants (Pret Latvijas Republiku vērsts aicinājums) - redakcijā, kas stājās spēkā 2016. gada 11. maijā, - un Krimināllikuma 149. ${ }^{1}$ pants (Diskriminācijas aizlieguma pārkāpšana).

Latvijas Republikas Augstākās tiesas tiesu prakses apkopojumā "Naida runa un vārda brīvība. Tiesu prakse krimināllietās par Krimināllikuma 74. ${ }^{1}$, 78., 150. pantu. 2012. gada oktobris - 2018. gada maijs" analizēti 42 Latvijas tiesu nolēmumi, to skaitā 39 nolēmumi (25 krimināllietās) par Krimināllikuma 78. pantu un divi spriedumi par Krimināllikuma 150. pantu [3, 4]. Tiesa norāda, ka minētajā laikposmā pēc Krimināllikuma $74 .{ }^{1}$ panta taisîts viens spriedums. Šajā lietā tiesa apstiprināja pirmstiesas procesā slēgtu vienošanos [4]. No lietas materiāliem izriet, ka 39 gadus vecā persona A. K. ievietojusi komentāru interneta portālā, kurā paustais attaisno Latvijas iedzīvotāju deportācijas. Tas bija viens no vairākiem personas A. K. apsūdzībā inkriminētajiem internetā paustajiem komentāriem. Pārējie personas A. K. komentāri tika kvalificēti pēc Krimināllikuma 78. panta otrās dal̦as. Tiesa personai A. K. noteica brīvības atṇemšanas sodu uz trim mēnešiem. Soda izpildes veids noteikts nosacìts ar pārbaudes laiku uz septiniem mēnešiem. Pārbaudes laiks noteikts vienāds ar galīgo soda laiku - septinin mēneši -, ko veidoja, daḷēji saskaitot sodus pēc Krimināllikuma 74. ${ }^{1}$ panta un pēc Krimināllikuma 78. panta otrās daḷas.

Analizējot tiesu praksi lietās pēc Krimināllikuma 78. panta, savā rakstā "Kriminālatbildība par religíiskā naida vai nesaticības izraisī̌sanu” jau secināju, ka naidīgu izteikumu izplatišanas galvenā vieta ir internets $[28,10]$. Arī tiesu prakses apkopojumā norādìts, ka no 25 aplūkotajām krimināllietām 24 bijušas par personu saukšanu pie kriminālatbildības pēc Krimināllikuma 78. panta otrās daḷas par darbībām, kas vērstas uz nacionālā, etniskā, rasu vai reliǵiskā naida vai nesaticības izraisiš̌anu, izmantojot automatizētu datu apstrādes sistēmu [3, 36]. Apkopojumā ietvertajos nolēmumos izteikumi bijuši ievietoti šādās interneta vietnēs: $w w w$.rus.delfi.lv - septiṇi, www.facebook.com - četri, www.ves.lv četri, www.apollo.lv - četri, www.delfi.lv - trīs, www.tvnet.lv - divi, www.ehorigi.lv - viens, www.draugiem.lv - viens, www.youtube.com - viens [3, 36]. Apkopojumā atzīmēts, ka komentāri, kas skatīti vienas krimināllietas ietvaros, varēja būt ievietoti vairākās interneta vietnēs. Komentāri tika veikti attiecībā uz dažādām etniskām un reliğiskām grupām: ebrejiem - desmit, latviešiem - aston,i, krieviem - trīs, romiem - viens, musulmañiem viens, melnādainajiem - viens [3, 34].

Apkopojuma aptvertajā periodā par noziedzīgu nodarījumu, kas paredzēts Krimināllikuma 78. panta otrajā dạ̦ā, par vainīgām atzìtas 23 personas, to skaitā viena sieviete un 22 vīrieši [3, 37-38]. Analizējot tiesu praksi lietās pēc Krimināllikuma 78. panta otrās daḷas, var konstatēt, ka pantā paredzēto noziedzīgo nodarījumu izdara statistiski vidēji 41 gadu vecs vīrietis, un tas ir pretrunā ar sabiedrībā pastāvošajiem uzskatiem, ka biežāk šāda veida noziegumus izdara pusaudži. Analizējot piemērotos sodus, konstatējams, ka biežāk šis vīrietis ir nosaciti sodīts ar brīvības atṇemšanu vidēji uz deviṇiem mēnešiem un 20 dienām, ar pārbaudes laiku vidēji uz 10 mēnešiem un trim dienām [3, 39-40]. 
Apkopojumā minēti tikai trīs "reālie sodi" lietās pēc Krimināllikuma 78. panta otrās daḷas: brīvības atṇemšanas laiks - četri mēneši (galīgais sods noteikts septiṇi mēneši, daḷēji pievienojot neizciesto sodu pēc cita sprieduma) un piespiedu darbs (100 stundu vienā gadījumā un 140 - otrā) $[3,40]$.

Tiesu prakses apkopojumā "Naida runa un vārda brīvība. Tiesu prakse krimināllietās par Krimināllikuma 74. ${ }^{1}$, 78., 150. pantu. 2012. gada oktobris - 2018. gada maijs" ir norādīts, ka šajā periodā pēc Krimināllikuma 150. panta spēkā stājušies spriedumi divās lietās. Abās lietās personas atzìtas par vainīgām noziedzīga nodarījuma izdarīšanā, kas paredzēts Krimināllikuma 150. panta trešajā dą̧ā (darbība saistīta ar vardarbību un draudiem) [3, 43]. 2017. gada 15. februārī Tukuma rajona tiesa atzina, ka persona M. B. (24 gadus vecs vīrietis) veica darbības, ka vērstas uz naida un nesaticības izraisǐšanu pret personām vinu sociālās piederības dēl, ievietojot komentārus savā profilā sociālajā tīklā www.facebook.com [6]. Personas M. B. publicētie izteikumi satur draudus un aicinājumu uz vardarbību pret imigrantiem. Persona M. B. par Krimināllikuma 150. panta trešajā dạ̦ā paredzēto noziedzīgo nodarījumu tika sodìta ar piespiedu darbu uz 160 stundām.

Savukārt 2018. gada 10. janvārī Talsu rajona tiesa atzina, ka persona I. R. (34 gadus vecs vīrietis) veica darbïbas, kas vērstas uz naida un nesaticības izraisī̌̌anu pret personām viṇu seksuālās orientācijas dēḷ, ievietojot komentāru savā profilā sociālajā tīklā www.facebook.com [5]. Personas I. R. publicētie izteikumi pauda atbalstu fiziskai vardarbībai pret homoseksuāliem cilvēkiem. Notiesātais I. R. no soda atbrīvots saskaṇā ar Krimināllikuma 58. panta pirmo daḷu (No kriminālatbildības var atbrīvot personu, kas izdarījusi noziedzīgu nodarījumu, kuram gan ir šajā likumā paredzētā nodarījuma pazīmes, bet ar kuru nav radīts tāds kaitējums, lai vajadzētu piespriest kriminālsodu) un 59. panta trešo dalı (Tiesa personu var atbrīvot no soda arī šā likuma 58. pantā paredzētajos gadijumos) [2].

Pārbaudot ANO Rasu diskriminācijas izskaušanas komitejas publicēto informāciju par nelielo Latvijā reǵistrēto naida noziegumu skaitu [8], secinu, ka minētā informācija ir statistiski pamatota. Iekšlietu ministrijas Informācijas centra dati liecina, ka no 2009. gada 1. janvāra līdz 2014. gada 1. janvārim pēc Krimināllikuma 78. panta tika uzsākti 62 kriminālprocesi (2009. gadā - seši, 2010. gadā - septiṇi, 2011. gadā - 12, 2012. gadā - 17, 2013. gadā - 20), kas ir par 30 kriminālprocesiem vairāk nekā analogiskā laikposmā no 2014. gada 1. janvāra līdz 2019. gada 1. janvārim [21].

Novērojot registrēto naida noziegumu pozitīvo dinamiku, tomēr jāatturas no prognozēm, ka arī turpmāk situācija būtiski mainīsies. Gluži otrādi - starptautiskā situācija kopumā un iekšpolitiskā situācijā Eiropas Savienības valstīs liecina, ka naida noziegumi un to apkarošana nezaudēs savu aktualitāti kā visā Eiropas Savienībā, tā arī katrā tās valstī atseviškiki. 


\section{Secinājumi}

1. Jēdzieni "naida noziegums" un "naida runa" Latvijas Republikas teritorijā nav normatīvi nostiprināti. Tas nozīmē, ka minēto jēdzienu izmantošana Latvijas tiesībaizsardzības iestāžu praksē ir iespējama tiktāl, ciktāl to piel̦auj Krimināllikuma robežas, jo pie kriminālatbildības Latvijas Republikas teritorijā saucama un sodāma tikai tāda persona, kura ir vainīga Krimināllikumā paredzētā noziedzīga nodarījuma izdarīšanā, ar atrunu, ka šim noziedzīgam nodarījumam ir visas noziedzīga nodarījuma sastāva pazīmes.

2. Latvijas Republikas teritorijā naida noziegumi galvenokārt izpaužas naida runas veidā, ievietojot aizvainojošus komentārus un publikācijas internetā, t. i., izmantojot automatizētu datu apstrādes sistēmu, lai veiktu darbības, kas vērstas uz nacionālā, etniskā, rasu, relig̣iskā vai sociālā naida vai nesaticības izraisišanu.

3. Personas tiesību un pamatbrīivibu izmantošanai vai realizēšanai jābalstās uz vienlìdzības pamatiem. Tādēl būtu lietderīgi veikt grozịjumus Krimināllikumā un noteikt vienādus sodus par darbībām, kas paredzētas Krimināllikuma 78. pantā (Nacionāla, etniska un rasu naida izraisišana) un Krimināllikuma 150. pantā (Sociālā naida un nesaticības izraisiš̌ana). Diskusijas vērts ir arī jautājums par šo pantu iekḷaušanu vienā Krimināllikuma nodaḷā.

4. Jākonstatē, ka 2012. gadā Eiropas Komisijas pret rasismu un neiecietību Ceturtajā ziṇojumā par Latviju izdarītais secinājums, ka par naida noziegumiem piespriestie sodi Latvijā ir pārāk saudzīgi [11], nav zaudējis aktualitāti arī mūsdienās, jo situācija šajā jomā nav mainījusies.

\section{Hate Crime in Latvia: Criminal Liability and Punishment}

\section{Abstract}

The European Commission against Racism and Intolerance (ECRI) on 5 March 2019 published Report on Latvia (fifth monitoring cycle). Non-governmental organisations, minority representatives and Ombudsman of the Republic of Latvia indicated to ECRI that victims of hate speech do not often report incidents to the police due to lack of trust in the willingness or ability of the law enforcement agencies to investigate these cases effectively.

ECRI recommends, as a matter of priority, that the authorities establish a unit within the State Police tasked with reaching out to vulnerable groups in order to increase trust in the police and address the problem of under-reporting of hate crimes. 
In 2012, the ECRI pointed out that penalties for racist violence (with a few exceptions, the imposition of custodial penalties) in Latvia are too lenient.

Therefore, the author offers his vision of the actual situation and how things have changed since the fourth ECRI Report on Latvia.

Keywords: hate crime, hate speech, triggering national, ethnic, racial, religious or social hatred.

\section{Avoti un literatūra}

\section{Tiesību akti}

1. Konvencija par jebkuras rasu diskriminācijas izskaušanu: starptautisks dokuments. Apvienoto Nāciju Organizācija. Iegūts no: http://www.mfa.gov.lv/ministrija/latvijas-parstavis-starptautiskajas-cilvektiesibu-institucijas/latvijas-republikas-nacionalie-zinojumi-par-starptautiskokonvenciju-izpildi/ano-1965-gada-konvencija-par-jebkuras-rasu-diskriminacijas-izskausanu/ ano-1965-gada-konvencija-par-jebkuras-rasu-diskriminacijas-izskausanu [sk. 23.04.2019.].

2. Krimināllikums: Latvijas Republikas likums: stājās spēkā: 01.04.1999. Latvijas Vēstnesis. 199/200(1260/1261), 08.07.1998.

\section{Tiesu prakse}

3. Naida runa un vārda brīvība. Tiesu prakse krimināllietās par Krimināllikuma $74 .{ }^{1}, 78 ., 150$. pantu. 2012. gada oktobris - 2018. gada maijs. Latvijas Republikas Augstākā tiesa. Iegūts no: http:// at.gov.lv/files/uploads/files/6_Judikatura/Tiesu_prakses_apkopojumi/2018/Naida runa un varda briviba_Apkopojums_2018_22_10_2018.doc [sk. 27.04.2019.].

4. Rīgas pilsētas Latgales priekšpilsētas tiesas 2013. gada 23. maija spriedums lietā Nr. 11840005812.

5. Talsu rajona tiesas 2018. gada 10. janvāra spriedums lietā Nr. 11380026317.

6. Tukuma rajona tiesas 2017. gada 15. februāra spriedums lietā Nr. 11390001416.

\section{Literatūra}

7. Baumanis, J. 2016. Naida interpretācija krimināltiesībās jeb kvantu kriminologija. Administratīvā un Kriminālā Justìcija. 4, 12-17.

8. Concluding observations on the combined sixth to twelfth periodic reports of Latvia. The Committee on the Elimination of Racial Discrimination. 2018. Iegūts no: https://tbinternet. ohchr.org/Treaties/CERD/Shared\%20Documents/LVA/CERD_C_LVA_CO_6-12_32235_E.pdf [sk. 23.04.2019.].

9. Dzelme, I. 2008. Naida noziegumu psiholoǵiskās sekas - cietušā pieredze un ietekme uz plašāku sabiedrību. Rīga: Latvijas Cilvēktiesību centrs.

10. ECRI Report on Latvia (Fifth monitoring cycle). The European Commission against Racism and Intolerance, Council of Europe. Iegūts no: https://rm.coe.int/fifth-report-on-latvia/1680934a9f [sk. 23.04.2019.].

11. Eiropas Komisijas pret rasismu un neiecietību ziṇojums par Latviju (ceturtais posms). The European Commission against Racism and Intolerance, Council of Europe. Iegūts no: https:// rm.coe.int/fourt-report-on-latvia-latvian-translation-/16808b58b8 [sk. 25.04.2019.].

12. Hate Crime Laws: A Practical Guide. Warsaw: Organization on Security and Cooperation in Europe, Office for Democratic Institutions and Human Rights, 2009. 
13. Hate Crime Statistics Act. Washington: U.S. Congress, House Committee on the Judiciary, Subcommittee on Criminal Justice, 1985.

14. Hate Crimes in the OSCE Region - Incidents and Responses. Annual Report for 2007. Warsaw: Organisation on Security and Cooperation in Europe, Office for Democratic Institutions and Human Rights, 2008.

15. Iganski, P. 2008. Hate Crime and the City. Bristol: Policy Press.

16. Kamenska, A., Trel̦s, Ë. 2017. Naida noziegumi: prakse un problēmas. Rīga: Latvijas Cilvēktiesibbu centrs.

17. Kinis, U. 2015. Kibernoziedzìba, kibernoziegumi un jurisdikcija. Rīga: Jumava.

18. Krastin̦š, U. 2000. Noziedzīgs nodarījums. Rīga: Tiesu namu aǵentūra.

19. Krastiṇš, U., Liholaja, V. 2018. Krimināllikuma komentāri. Otrā daḷa (IX-XVII nodaḷa). Otrais papildinātais izdevums. Rìga: Tiesu namu aǵentūra.

20. Krastiṇš, U., Liholaja, V., Hamkova, D. 2016. Krimināllikuma komentāri. Otrā daḷa. Rīga: Tiesu nama aǵentūra.

21. Kriminālā statistika. Latvijas Republikas Iekšlietu ministrijas Informācijas centrs. Iegūts no: http://www.ic.iem.gov.lv/node/109 [sk. 25.04.2019.].

22. Latviešu literārās valodas vārdnīca. 2. sēj. Rīga: Zinātne, 1973.

23. Latviešu literārās valodas vārdnīca. 5. sēj. Rīga: Zinātne, 1984.

24. Latviešu literārās valodas vārdnīca. 6. sēj., 2. daḷa. Rīga: Zinātne, 1987.

25. Naida runas un naida noziegumu atpazīšanas un izmeklēšanas prakses problēmaspekti Latvijas Republikā. Latvijas Republikas Tiesībsarga birojs. 2016. Iegūts no: http://www.tiesibsargs.lv/uploads/content/publikacijas/naida_noziegumu_un_naida_runas_izmeklesana_ lv_2016_1496214733.pdf [sk. 25.04.2019.].

26. Perry, B. 2001. In the name of hate: Understanding hate crimes. New York: Routledge.

27. Recommendation No. R (97)20 of the Committee of Ministers to Member States on "Hate Speech". Council of Europe. Iegūts no: https://rm.coe.int/1680505d5b [sk. 26.04.2019.].

28. Trẹ̦s, E. . 2017. Kriminālatbildība par reliǵiskā naida vai nesaticības izraisīšanu. Rīgas Stradiṇa universitātes Juridiskās fakultātes elektroniskais juridisko zinātnisko rakstu žurnāls Socrates. 1(7), 9-19.

29. Trel̦s, E. 2016 . Teksta juridiskās ekspertīzes īpašības lietās par naida izraisīšanu. Rīgas Stradiṇa universitātes Juridiskās fakultātes elektroniskais juridisko zinātnisko rakstu žurnāls Socrates. 1(4), 46-56.

30. Trel̦s, Ė. 2012. Valsts policijas darbs daudznacionālajā sabiedrībā. Zinātniskā monogrāfija. Rīga: P\&K.

31. Vadlīnijas "naida noziegumu" identifikācijai un izmeklēšanai: Valsts policijas 2017. gada 4. augusta pavēle Nr. 3487. Latvijas Republikas Iekšlietu ministrijas Valsts policija. Iegūts no: http://www.vp.gov.lv/doc_upl/vadlin_naida_noziegumi_02.08.doc [sk. 25.04.2019.].

32. Vilks, I. 2008. Zinātniskā ētika jeb Domājošā cilvēka cel̦š. Rīga: Mācību grāmata. 
https://doi.org/10.25143/socr.13.2019.1.042-049

\title{
Phenomenon of Corruption, Its Origin in the Grand Duchy of Finland and the Level in Modern Finland
}

\author{
Dr. iur, MFA, Vladimir Jilkine \\ Law center, Helsinki, Finland \\ info@lawcenter.fi
}

\begin{abstract}
Power and corruption have been inseparable since ancient times. The phenomenon of corruption is of particular interest not only for scientists working in the field of social and humanitarian knowledge, but also for politicians, lawyers, philosophers and public figures. Almost all modern researchers consider corruption as a social phenomenon. The problems of corruption are reflected in the works of political scientists, economists, legal scholars, lawyers, philosophers, sociologists, offering a variety of approaches to the study of a multidimensional and debatable phenomenon. The UN views corruption as a complex social, cultural and economic phenomenon affecting all countries, but does not provide a more detailed explanation of the term. The concept of a "corruption offense" does not have a separate definition in Finnish legislation. Scientists and practitioners still have not come to a common opinion on the key issue: how to objectively determine the effective work of the anti-corruption institution and its impact on the corruption situation in the country. According to the author, studying the history, causes and extent of corruption in Finland will allow understanding of its evolution, causes and influence on the state to determine the regulatory framework in the field of anti-corruption legislation in Finland.

Keywords: historical roots of corruption, phenomenon of corruption, Grand Duchy of Finland, corruption levels, international cooperation.

Plato argued that in the history of mankind there has not yet been a state in which corruption did not shake the peak of political power with its vice. The writings of Aristotle, N. Machiavelli, T. Hobbes, S. Montesquieu on the state and public administration addressed the reasons for the existence, nature and consequences of corruption, its impact on social development. Also today these problems remain important and topical
\end{abstract}


due to the fact that almost all states, as mentioned above, are faced to one degree or another with manifestations of corruption.

The phenomenon of corruption is of particular interest not only for scientists working in the field of social and humanitarian knowledge, but also for politicians, lawyers, philosophers and public figures.

Almost all modern researchers consider corruption as a social phenomenon. The problems of corruption are reflected in the works of political scientists, economists, lawyers, philosophers, sociologists, offering a variety of approaches to the study of a multidimensional and debatable phenomenon.

Studying the history of corruption as a phenomenon after the Grand Duchy of Finland joined the Russian Empire will help understand the tendency and level of corruption in Finland in the $21^{\text {st }}$ century, as well as assessing the effectiveness of anti-corruption measures to create its own specialised institutions to prevent and combat corruption and reduce its level. The accumulated historical experience of Finland, international experience and coordination of international cooperation will help to provide additional guidance in the implementation of the criteria for the effectiveness of anti-corruption institutions in fighting corruption.

Studies by Finnish historians indicate the emergence of corruption long before the formation of the Grand Duchy of Finland.

The local Swedish merchants, who in 1710 received Peter I guarantees of privileges for the oath to the Russian throne, began to actively hold official positions in magistrates and courts, and from 1744 after the transformation of the Vyborg guberniya at the behest of Empress Elizabeth and in the provincial government.

Thus, Ph.D., associate professor in the field of municipal politics Silvo Kaasalainen reports that scholars and historians know that as early as the $18^{\text {th }}$ century in SwedenFinland, government posts were brazenly bought and sold. ${ }^{1}$

For example, Markku Kuisma, a Finnish professor of history, Ph.D., writes that as early as the 1770s, businessmen were playing a dual role in appointing crown fochts. ${ }^{2}$ This, however, did not lead to the emergence of special problems with the removal from office, even though they had "important administrative tasks to regulate sawmill from determining the amount of taxes to controlling production". ${ }^{3}$

${ }^{1}$ Kaasalainen, S. Virkanimitysruletti: miksi sopivin voittaa parhaan? Barrikadi-sarja No 22 (Eng. Appointment Roulette: Why is it best to win the best? Barricade Series No 22). Helsinki: WSOY. Werner Söderström Oy, 2011.

2 A state official in the Grand Duchy of Finland as the highest police officer, who was also a prosecutor, tax collector and bailiff. He also represented the executive branch in which the governorship generals acted as well as entrepreneurs (post was abolished only in 1945).

3 Kuisma, M. Kauppasahojen perustaminen Suomessa 1700-luvulla: Tutkimus päätöksentekoprosessista (Eng. Establishment of Trade Saws in Finland in the $18^{\text {th }}$ century: A study of the decisionmaking process). Väitöskirja. Helsinki: Societas Scientiarum Fennica. 1983. p.19. 
In March 1808, the Emperor and Autocrat All-Russian Alexander I announced to foreign states that he decided to unite Finland with his empire. On 5 (17) June 1808, Alexander I issued a manifesto "On the Accession of Finland", which stated that the emperor decided that Finland, under the rule of the Russian emperor, should live under the protection of its old constitutions and privileges. The members of the Sejm took the oath that "they recognise as their sovereign Alexander I the Emperor and Autocrat of the All-Russian Grand Duke of Finland, and they will preserve the fundamental laws and constitutions of the region as they currently exist". ${ }^{4}$

According to Markku Kuisma, the merchant class, which was engaged in sawmill production in the late 1700 s, was able to take power over a "plutocratic" or rich city administration. Large merchants and ship-owners also had better chances to influence government decisions and manage their own interests. ${ }^{5}$

Kuisma describes the history of the relationship between business, politics and government elites in the 1800s, when the "industrial aristocracy" and the new business class developed. The industrial aristocracy and the class of entrepreneurs were connected by family and family contacts with the old elite of officials, the class of teachers and owners of family estates and at the same time had political power. The advanced son of a lawyer or the son-in-law of the professor, the uncle of the capital senator who owns the sawmill, the governor's godson and cousin of the judge, the brother-in-law's brother-in-law who took the post of industrialist, and the Secretary of State of the Interparliamentary Assembly of St. Petersburg formed a network of interconnected, loyal and interdependent organizations of the Inter-Parliamentary Assembly of St. Petersburg. or wanted to influence the decisions of the power system. ${ }^{6}$

Kuisma concludes that a brief historical overview shows that the business community, especially the "timber industry bourgeois", tried to influence government decision making from the end of the $18^{\text {th }}$ century, giving gifts and corrupting officials. This practice was not new or unprecedented. ${ }^{7}$

After the defeat of Russia in the war with Japan, the internal political opposition to the imperial regime intensified. Unrest spread to Finland, where at the end of October 1905 a general strike began. The unrest led to the royal manifesto on the establishment of a parliament in Finland on the basis of the universal right to vote, with the authority to ensure the legitimacy of the measures taken by the government of the country.

${ }^{4}$ Rafael, E. Suomen valtio-oikeus. Tietosanakirja (Eng. Finnish State Law. Encyclopedia). Helsinki: Osakeyhtiön Kirjastopaino, 1924. p.42-43.

${ }^{5}$ Kuisma, M. Kauppasahojen perustaminen Suomessa 1700-luvulla: Tutkimus päätöksente- koprosessista (Eng. Establishment of Trade Saws in Finland in the $18^{\text {th }}$ century: A study of the decisionmaking process). Väitöskirja. Helsinki: Societas Scientiarum Fennica, 1983. p.150.

${ }^{6}$ Kuisma, M. Kauppasahojen perustaminen Suomessa 1700-luvulla: Tutkimus päätöksente- koprosessista (Eng. Establishment of Trade Saws in Finland in the $18^{\text {th }}$ century: A study of the decisionmaking process). Väitöskirja. Helsinki: Societas Scientiarum Fennica, 1983. p. 178.

7 Ibid., p. 150. 
The parliamentary reform of 1906 accelerated the creation of political parties and over the past decades political parties have become a central part of all political activity. After the adoption of the law on parties in 1969, the parties were also a legally integral part of state institutions that still influence government decision-making.

Before the parliamentary elections of 1922, the trade and industry election commission announced that it would finance campaigns of bourgeois parties, subject to nomination of candidates approved by business as general candidates.

During the parliamentary elections of 1939, the industry began to plan collection of electoral funds to influence and direct agitational work on the peasantry and the "middle class". ${ }^{8}$

The amount of bribes received in $1970-1980$ by officials in Finland according to the charges ranged from 1,000 to 28,000 Finnish marks (168-4,706 euros). At the same time, according to the Statistical Center, the average monthly salary (in terms of Finnish marks) in Finland in 1960 was 77 euros, in 1980 it was 625 euros. ${ }^{9}$

In addition, in the courts of Finland quite often criminal charges of corruption offenses were considered simultaneously with the charges under economic articles; therefore, there is no exact data on the number of convictions in receiving and paying bribes.

Hidden crime in Finland was studied in 1973 by a professor at the University of Tampere, Pertti Hemanus. From his point of view, "Hidden crime is a problem in the fight against bribery and corruption in general. The information obtained from statistics does not give a complete picture of the reality of corruption". ${ }^{10}$

Ahti Laitinen, a doctor of political science and a professor of criminology, wrote about the role of the president back in 1986:
"Although in practice the president submits a foreign policy report to both the Foreign Affairs Committee of the Parliament and the government, in practice the role of Parliament in managing foreign policy is secondary. The weakening of the position of Parliament in the system of relations of state power is partly due to the circumvention of the policy around the president, which was especially noticeable in Finland in the 1960s and 1970s". 11

In the early 1980s, the change of power of higher state institutions was initially caused only by a change of president, and then rather quickly progressed to significant changes to the constitution and the separation of government power. Already

\footnotetext{
${ }^{8}$ Kuisma, M. Kauppasahojen perustaminen Suomessa 1700-luvulla: Tutkimus päätöksente-koprosessista (Eng. Establishment of Trade Saws in Finland in the $18^{\text {th }}$ century: A study of the decisionmaking process). Väitöskirja. Helsinki: Societas Scientiarum Fennica. 1983. p. 85. URL: https:// www.stat.fi/artikkelit/2012/art_2012-03-12_004.html.

9 URL: https://www.stat.fi/artikkelit/2012/art_2012-03-12_004.html.

${ }^{10}$ Hemanus Pertti. Joukkotiedotus piilovaikuttajana (Eng. Mass media as a hidden influence). Delfiinikirjat. Helsinki: Otava, 1973. p. 109.

${ }^{11}$ Laitinen, A. Yhteiskunnallinen vallankäyttö ja korruption mahdollisuudet (Eng. Social use of power and opportunities for corruption). Turku. 1986. p. 54.
} 
in the 1970s and at the turn of the 1980s, a period of change and transformation of the elite began.

The topic of bribing civil servants became widely discussed in the second half of the 1970s in connection with the so-called Salora case. According to the court's decision, Salora's CEO Jouko Nordell bribed politicians and senior officials and paid for their travel abroad. 6 million Finnish marks passed by the financial statements. As a result, the company's general director received 3.5 years in prison for bribing five ministers, two heads of office, the mayor and 30 employees of the tax department.

In the 1980s, wide public attention was directed to discussing a number of cases of bribing officials, trust and impartiality of government.

In 2009, Finnish State Attorney Jukka Rappe stated that there is no structural corruption in Finland, but there is a well-established scheme of "cronyism" (hyvä veli verkosto) according to the "You to me - I to you". Corruption in power was the subject of many Finnish political scientists and lawyers in the years 1970-1980.

During the presidential term of Urho Kekkonen, many government ministers Harri Hermanni Holkeri (30.04.1987-26.4.1991) received high-ranking positions. For example, Kalevi Sorsa on the Executive Board of the Bank of Finland, Erkki Liikanen was appointed ambassador to the European Union, Ilkka Suominen as director of Alko, Pekka Vennamo as director general of the post office and television broadcasting, Helena Pesola as director of the pension department, and Kai Bärlund as director general of the environment center, and 1995-2007 Head of the UNECE Environment Commission.

Previously appointed Minister of the Interior (1982-1983), Minister of the Environment (1983-1987) Matti Ahde, after the expiration of his term as deputy speaker of the Finnish Parliament in 1990, was immediately appointed managing director and elected a member of the board, and then chairman of the board in 1990-1999 State Association of slot machines of Finland RAY.

Also note that Holkeri government reforms have significantly increased the number of civil servants in ministries. At the beginning of the Harri Holkeri government (1988-1991), the government apparatus numbered 214,000 civil servants, and in 1990 it was 147,000 people, and by 1995 it was 124,000 . For comparison, in 2010 the number of civil servants in Finland exceeded 80,000.

The condition of the long-term stability of the activities of public servants in Finland is partly reflected in the fact that the State Civil Service Act of 1924 remained in force for more than 60 years - until 1986.

One of the effective social technologies to combat corruption is the formation of public consciousness of zero tolerance for corruption crimes in Finland. This is possible only if the formation of an anti-corruption outlook and therefore the main role belongs to the media.

Analysis of scientific publications and generalisations of court practice lead to the conclusion that corruption in Finland has a very high latency. Reports of the Ministry of Justice, the highest police school indicate the real situation of corruption in Finland, 
including the hidden corruption in many areas of municipalities. Bribery, however, is only one form of corruption. Corruption is also noted in cases of "acquaintance" relations, in cases of nepotism or nepotism, as well as violations of good management and administration practices.

Special mention should be made of the special role of journalists and the frequency of coverage of Finnish media on television channels of information on corruption facts among members of the parliament, senior police and prosecutors, and representatives of big business with further coverage of court hearings and court decisions.

For example, in their investigation journalists Tuomo Pietiläinen and Niko Vartiainen presented a pre-election analysis of the Finnish representatives of the municipal government.

"Now there are 395 politicians in the municipal councils of Finland who over the past five years have been convicted of committing a total of 705 offenses during the period 2012-2017. Of these, 99 politicians were sentenced to prison or to a suspended prison sentence. During this period, Finnish politicians received charges of beating and causing harm to life and health in 140 crimes. The degree of intoxication of $2.5 \mathrm{ppm}$ of alcohol and more was recorded in seven politicians, and the maximum level of alcohol was 3.11 ppm was recorded in Finnish politics in 2015". ${ }^{12}$

Before the parliamentary elections in 2019, journalists presented new data: in the period 2005-2019. 318 deputies who are candidates for the parliament in the elections of April 14, 2019, were charged with criminal offenses, which accounted for $12.9 \%$ of the total number of 2,468 candidates for deputies. Among women candidates, criminal charges accounted for $14 \%$.

For example, only in one party of the Seven Stars Movement out of 175 declared candidates, 103 had criminal charges. The sentence of imprisonment for 3 years and 4 months for aiding in a serious drug offense was received on February 11, 2018 by a candidate for the Parliament of Kim Holviala, awaiting a review of the case in the appellate court at large. For attempted murder and the threat of murder or the infliction of grievous bodily harm, the candidate for the Parliament Sami Salonen was sentenced to 3 years and 6 months in prison. The maximum penalty among female candidates for Parliament is the county court determined Minna Engström for a period of 1 year and 4 months for a serious economic crime and further banned business activities until the end of $2021 .^{13}$

Analysing judicial practice in Finland, it can be concluded that the courts of all instances apply much less severe penalties, for example, imposing minor fines.

12 Pietiläinen, T., Vartiainen, N. Kuntapäättäjien rikoksia piilossa äänestäjiltä (Eng. Crimes of municipal decision-makers are hidden from the voters). HS. 24.9.2017.

13 Pietiläinen,T., Räisänen, K., Laatinen, J. Sadat edusuntaan pyrkivät olleet syytteessä rikoksista (Eng. Hundreds of leaders have been charged with crimes). HS. 7.4.2019. 
To prevent corruption, it is necessary to develop policies, analytical research, monitoring and coordination of actions to combat corruption, as well as monitoring their implementation and evaluating their effectiveness.

It is necessary to prevent conflicts of interest, check declarations of property of officials and ensure public access to this information. Mechanisms for the implementation of these functions can be financial control, measures to prevent legalisation of proceeds of crime, measures to achieve transparency in public procurement.

The preventive function is to increase the transparency of the public service, ensure open access to information by the public and ensure control over financing of activities and elections of political parties.

Education and educational function includes development and conduct of educational programmes for the public and public servants, and work with the media, public organisations and the public.

In conclusion, it is necessary to emphasise that there is no single recipe for resisting corruption. The fight against corruption requires close coordination of international cooperation and law enforcement agencies, analysis of statistical data on corruption cases, provision of legal assistance, execution of extradition court decisions and international readmission obligations.

\section{Korupcijas fenomens, tā aizsākumi Somijas Lielhercogistē un loma mūsdienu Somijā}

\section{Kopsavilkums}

Ietekme un korupcija ir bijuši saistīi kopš seniem laikiem. Korupcijas fenomens ir īpaši saistošs ne vien sociālo un humanitāro zinātṇu ekspertiem, bet arī politiḳiem, juristiem, filozofiem un sabiedrību ietekmējošām personībām. Gandrīz visi mūsdienu pētnieki uzskata korupciju par sociāla tipa fenomenu. Korupcijas riskus un to ietekmi apraksta politikas zinātnes pārstāvji, ekonomisti, jurisprudences akadēmiskais personāls, filozofi, sociologi, piedāvājot dažādas pieejas šì multidimensionālā un diskusiju vērtā fenomena aplūkošanā. ANO definē korupciju kā kompleksu sociālo, kultūras un ekonomikas fenomenu, kas ietekmē visas valstis, bet sīkāku termina skaidrojumu tam nesniedz. "Korupcijas pārkāpuma" konceptam arī somu likumdošanā nav savas definīcijas. Pètnieki un praktiḳi līdz šim nav vienojušies par kopēju redzējumu korupcijas sakarā: kā objektīvi izvērtēt pretkorupcijas institūciju darba efektivitāti un to ietekmi uz korupcijas risku mazināšanu valstì. Pēc šì raksta autora domām, korupcijas vēstures liecību, cēloṇu un apjoma pētījumi l̦aus izprast šĩ fenomena attīstìbas tendences valstī, tās cēloṇus un ietekmi uz valsts pārvades struktūru, un sekmēs tādas likumdošanas izstrādi, kas regulē korupcijas risku mazināšanu Somijā. 
Vladimir Jilkine. Phenomenon of Corruption, Its Origin in the Grand Duchy of Finland and the Level in Modern Finland

Atslēgvārdi: korupcijas vēsturiskā izcelsme, korupcijas fenomens, Somijas Lielhercogiste, korupcijas līmeṇi, starptautiskā sadarbība.

\section{References}

1. Hemanus, P. (1973). Joukkotiedotus piilovaikuttajana (Eng. Mass media as a hidden influence). Delfiinikirjat. Helsinki: Otava.

2. Kaasalainen, S. (2011). Virkanimitysruletti: miksi sopivin voittaa parhaan? Barrikadi-sarja No 22 (Eng. Appointment Roulette: Why is it best to win the best? Barricade Series No 22). WSOY. Werner Söderström Oy. Helsinki.

3. Kuisma, M. (1983). Kauppasahojen perustaminen Suomessa 1700-luvulla: Tutkimus päätöksentekoprosessista (Eng. Establishment of Trade Saws in Finland in the $18^{\text {th }}$ century: A study of the decision-making process). Väitöskirja. Helsinki: Societas Scientiarum Fennica.

4. Laitinen, A. (1986). Yhteiskunnallinen vallankäyttö ja korruption mahdollisuudet (Eng. Social use of power and opportunities for corruption). Turku.

5. Pietiläinen, T., Vartiainen, N. Kuntapäättäjien rikoksia piilossa äänestäjiltä (Eng. Crimes of municipal decision-makers are hidden from the voters). HS. 24.9.2017.

6. Rafael, E. (1924). Suomen valtio-oikeus. Tietosanakirja (Eng. Finnish State Law. Encyclopedia). Helsinki: Osakeyhtiön Kirjastopaino.

7. Pietiläinen, T., Räisänen, K., Laatinen, J. Sadat edusuntaan pyrkivät olleet syytteessä rikoksista (Eng. Hundreds of leaders have been charged with crimes). Helsingin Sanomat. 7.4.2019. 
https://doi.org/10.25143/socr.13.2019.1.050-062

\title{
Cilvēku tirdzniecība: kriminoloǵiskās problēmas
}

\author{
Dr. iur. Andrejs Vilks \\ Dr. iur. Aldona Kipāne \\ Rīgas Stradiña universitāte, Juridiskā fakultāte, Latvija \\ Andrejs.Vilks@rsu.lv \\ aldonakipane@inbox.lv
}

\section{Kopsavilkums}

Rakstā tiek apskatītas ar cilvēku tirdzniecību saistītās kriminolog̣iskās problēmas un ir sniegts ieskats par problēmjautājumiem, kas skar šì sociāli tiesiskā fenomena kriminoloğiskās izpētes aspektus.

Cilvēku tirdzniecība ir dinamiska parādība, kas viegli pielāgojas mainīgiem apstākḷiem. Tradicionāli cilvēku tirdzniecība ir organizētās noziedzības veids. Cilvēku tirdzniecību veicina daudzveidīgu cēloṇu un apstākḷu kopums. Viens no cilvēku tirdzniecības dzinējspēkiem ir sociālo un ekonomisko procesu globalizācija. Tādēl cilvēku tirdzniecības prevencijas pasākumiem jāiedarbojas uz plašām sabiedrības dzīves jomām.

Atslēgvārdi: cilvēku tirdzniecība, kriminologiskās problēmas, kriminologiskā izpēte, faktori.

\section{levads}

Cilvēku tirdzniecība nav jauna parādība, un pirmsākumos tā bija legāla - sociāli un juridiski beztiesisku cilvēku jeb vergu atrašanās cita cilvēka īpašumā. Eksperti ir aprēķinājuši, ka laikposmā no 15. līdz 19. gadsimtam par vergiem tika pārdoti aptuveni 15 miljoni cilvēku. Mainoties sociāli ekonomiskajiem, politiskajiem un tiesiskajiem apstākḷiem, cilvēku tirdzniecības problēmai, šḳiet, bija jāizzūd vai būtiski jāmazinās. Lai arī ir pagājuši vairāk nekā 200 gadi kopš verdzības aizliegšanas, visā pasaulē aizvien notiek cilvēku tirdzniecība, un tas ir vardarbības un paverdzināšanas veids, kas turklāt kvantitatīvi paplašinās. 
2002. gadā, pievēršoties cilvēku un viṇu orgānu tirdzniecības problēmai, mēs, balstoties uz ASV Centrālās izlūkošanas pārvaldes datiem, konstatējām, ka pasaulē bija aptuveni 27 miljoni vergu [Vilks, 2002]. Pašlaik tiek norādìts, ka aptuveni 40 miljoni cilvēku visā pasaulē ir cilvēku tirdzniecības upuri - tas ir mūsdienu verdzības veids, kurā tirgotāji izmanto vardarbību, spēku, krāpšanu vai piespiešanu, lai kontrolētu gan pieaugušos, gan bērnus [International Labour Office, 2017].

Publiskajā vidē ir pieejami arī citi dati par cilvēku tirdzniecības upuru skaitu. Austrālijas fonds Walk Free, ko ir izveidojis miljardieris Endrjū Forests, katru gadu apzina verdzības stāvokli pasaulē. Aptaujājot četrdesmit divus tūkstošus cilvēku divdesmit piecās pasaules valstīs, fonda darbinieki secināja, ka šobrīd pasaulē dzīvo 45,8 miljoni vergu [The Minderoo Foundation].

Cilvēku tirdzniecība ir izplatìta starptautiskā mērogā, taču var īstenoties arī vienā valstī vai pat vienā kopienā. Latvija ir kḷuvusi par cilvēku tirdzniecības upuru izcelsmes valsti. Piekrītam viedoklim, ka "svarīgi ir apzināties, ka viss sākas ar cilvēku tirdzniecības apzināšanos par noziegumu ar loti mainīgām pielietošanas metodēm. Sabiedrības informētība, spēja izdarìt secinājumus un aktīva pozīcija ir priekšnoteikums, lai šādi noziegumi neturpinātos, tiktu atpazìti un par tiem būtu paredzēti adekvāti sodi likumos, un noziegumu veicēji saṇemtu sodu, bet upuri - palīdzību" [Ivančiks, 2008].

Cilvēku tirdzniecība joprojām ir ḷoti ienesīgs nelegālais bizness. Tā ir sociāla, tiesiska un veselības aprūpes problēma, kura rada draudus indivīdam, valstij un arī visai pasaulei.

\section{Darba mērķis}

Pētījuma mērḳis ir raksturot gan cilvēku tirdzniecības kriminolog̣iskās problēmas, atklājot cilvēka tirdzniecības fenomena jēdzienu un izpētot vispārējās tendences pasaulē un Latvijā, gan arī šìs parādības faktorus. Uzskatām, ka šĩ fenomena kriminologisko īpatnību izpēte ir svarīgs aspekts cilvēku tirdzniecības novēršanai, jo kriminologiskā raksturojuma specifiskie elementi palīdz noteikt preventīvā darba prioritāros virzienus.

\section{Materiāls un metodes}

Pētījuma bāze ir dažādos pētījumos izdarītie secinājumi, zinātnieku un speciālistu atziṇas un viedoḳ̣i, kriminālās statistikas dati un prakses piemēri. Kriminologiisko parādību un likumsakarību izziņai tika izmantotas vispārējās un speciālās juridiskās izziņas metodes: speciālās un juridiskās literatūras avotu referatīva analīze, aprakstošā metode, detalizēti pētot pētỉjuma priekšmetu, statistiskā datu apstrādes metode. 
Andrejs Vilks, Aldona Kipāne. Cilvēku tirdzniecība:

kriminologiiskās problēmas

\section{Cilvēku tirdzniecība kā kriminoloǵiskās izpētes priekšmets}

Cilvēku tirdzniecība ir nelikumīga cilvēku aizvešana ar varu, izmantojot spēku, krāpšanu un viltu, vai pārdošana seksuālajai ekspluatācijai vai piespiedu darbam [Bernat and Zhilina, 2010]. Jau vēsturiski cilvēku tirdzniecība ir saistīta ar divām atsevišçām parādībām - prostitūciju un verdzību, kurām ir arī savstarpēja saistība [Ivančiks, 2008]. Cilvēku tirdzniecībā tiek netaisnīgi izmantotas neaizsargātas, ievainojamas personas, kuras noziedznieki tirgo kā preces ekonomiskā labuma iegūšanai. Personas ekspluatācija nozīmē personas izmantošanu dažādos veidos - prostitūcijai vai citām seksuālās ekspluatācijas formām, piespiedu darbam vai pakalpojumiem, verdzībai vai verdzībai līdzīgai praksei, kalpībai vai orgānu izṇemšanai, kā arī fiktīvām laulībām. Termina "cilvēku tirdzniecība" definīciju nosaka šis parādības evolūcija un izmaiņas vēsturiskajos apstākḷos (ekonomiskā, sociālā, politiskā un kultūras ziṇā), to kodifikācija sociālpolitiskajā, zinātniskajā, juridiskajā un starptautiskajā diskursā [Glonti, 2004]. Šodien - atvērtās pasaules laikā - cilvēku tirdzniecība uzṇem jaunus apgriezienus, apdraudot personu brīvību, drošỉbu un arī dzīvību.

Cilvēku tirdzniecības pamatā ir trīs elementi: darbība (kāda darbība tiek veikta), paṇēmiens (kā viss tiek izdarīts) un ekspluatācijas mērḳis (kāds ir nolūks). Tas ir smags noziegums, upura l̦aunprātīga izmantošana, cilvēka pamattiesību un cieñas aizskaršana. Profesore Jūlija O'Konela Deividsone (Julia O'Connell Davidson) uzskata, ka modernā verdzības forma bieži vien ir nežēlīgāka un bīstamāka par to, kāda tā bija verdzības iekārtā; tiesiskā verdzība (legal slavery) Amerikā un citviet pasaulē vergiem sniedza zināmu autonomiju. Modernā cilvēktirdzniecība ir prettiesiska darbība, tādēḷ tai ir augsts latentātes un noklusēšanas līmenis [Davidson, 2011]. Turklāt globālās ekonomikas attīstības un migrācijas procesu rezultātā pieprasījums veicina piedāvājumu. Cilvēku tirdzniecība ir plaši izplatìta, nelikumīga, to ir grūti novērst un apkarot. Tā nodara neatgriezenisku kaitējumu upuriem un sabiedrībai.

2019. gada ASV Valsts departamenta ziṇojumā "Par cilvēku tirdzniecības novēršanu" ir norādīts, ka Latvijas valdība pilnībā nepilda minimālos standartus, lai apkarotu cilvēku tirdzniecību, tomēr tā pieliek ievērojamas pūles, lai tos ieviestu, tādēḷ Latvijas darbs cīnā pret cilvēku tirdzniecību ir novērtēts atbilstoši 2. līmenim [ASV Vēstniecība Latvijā, 2019]. Jāatzīst, ka noziedzības, tostarp cilvēku tirdzniecỉbas, objektīvo rādītāju stāvoklis un reāla noziedzības novēršana un apkarošana ir sarežğìta problēma visā pasaulē. Faktiskais noziegumu skaits ir vairākas reizes lielāks par reǵistrēto noziegumu skaitu. Cilvēku tirdzniecības latentāte ir globāla problēma, kas ir aktuāla arì katrā konkrētā valstī [ASV Vēstniecība Latvijā, 2018].

Latvijā cilvēku tirdzniecības problēmas tika apzinātas pēc Padomju Savienības sabrukuma. Divdesmitā gadsimta beigu un jaunās tūkstošgades globālās civilizācijas attīstības tendencēm vērojamas jaunas īpatnības un standarti, kam ir ne tikai politiska, sociāla, tiesiska, bet arī kriminologiska nozīme [Starptautiskā migrācijas organizācija, 
2006]. Cilvēku tirdzniecība var tikt analizēta kā pretdarbība organizētajai noziedzībai; legālā un nelegālā migrācija; nodarbinātības problēma; morāles un uzvedības normu problēma; problēma, kas tiešã veidā saistìta ar prostitūciju; cilvēktiesību pārkāpums [Starptautiskā migrācijas organizācija, 2006]. Mūsdienu pētījumos un starptautiskajos dokumentos šì problēma ir pietiekami plaši un detalizēti analizēta, aprakstot fenomena procesus, tendenci, tā formu un metodi.

Latvijā par nodarïjumiem, kas saistīti ar cilvēku tirdzniecību, persona var tikt krimināli sodìta atbilstoši diviem Krimināllikuma (turpmāk - KL) pantiem: KL 154. ${ }^{1}$ pantam (Cilvēku tirdzniecība) un $165 .{ }^{1}$ pantam (Personas nosūtǐšana seksuālai izmantošanai). KL $154{ }^{2}$ panta pirmajā dạ̦ā cilvēku tirdzniecība ir definēta šādi: ekspluatācijas nolūkā izdarīta personu savervēšana, pārvadāšana, nodošana, slēpšana, izmitināšana vai saṇemšana, lietojot vardarbību vai draudus, vai aizvešanu ar viltu vai izmantojot personas atkarību no vainīgà vai tās ievainojamības vai bezpalīdzības stāvokli, vai arī dodot vai saṇemot materiāla vai citāda rakstura labumus, lai panāktu tās personas piekrišanu tirdzniecībai, no kuras ir atkarīgs cietušais.

Kriminologijā tiek uzskatīts, ka noziedznieks, upuris un noziedzīga nodarījuma situācija ir savstarpēji cieši saistīti elementi. Tie veido vienotu sistēmu, kas var pastāvēt tikai tad, ja ir šie elementi [Zadorozniy, 2005]. Neviens jau nevēlas kḷūt par cietušo noziedzīgā nodarījumā, un risks kḷūt par noziedzịga nodarījuma upuri iedzīvotāju vidū sadalās nevienmērīgi. Kḷūšana par upuri ir process, kurā ir svarīgas sistemātiskas vides, demogrāfiskās un personīgās īpašības [Walsh and Forgenson, 2018]. Jāṇem vērā, ka dažas personu grupas var kḷūt par noziedzīga nodarījuma upuri sava fiziskā stāvokḷa, dzimuma, vecuma, rakstura iezīmju dēḷ. Cilvēku tirdzniecības viktimologiskajai prevencijai ir noteikta specifika, kas ir saistita ar upura personïbu.

Lai gan cilvēku tirdzniecība aptver visus demogrāfiskos rādītājus, pastāv noteikti gadījumi vai ievainojamības apstākḷi, kuri paaugstina risku kḷūt par cilvēku tirdzniecības upuri. Kā skaidrots KL 154. ${ }^{2}$ panta ceturtajā daḷā, cietušã aizvešana, izmantojot vina ievainojamību, nozīmē, ka tiek izmantoti apstākḷi, kad personai nav citas reālas vai pieñemamas izvēles kā vien pakḷauties ekspluatācijai. Kā pamats upura ievainojamìbai var būt sociālie faktori - nabadzība, disfunkcionāla gimene, fiziskās vai garīgās veselïbas problēmas, atkarība no alkohola, narkotikām vai psihotropām vielām [Krastiņš un Liholaja, 2016]. To ilustrē tiesu prakses piemērs: "pers. C., darbojoties personu grupā pēc iepriekšējas vienošanās, ar viltu savervēja, pārvadāja un nosūtīja no Latvijas Republikas uz Kipras Republiku ekspluatācijai Latvijas pilsoni, pers. I., izmantojot vinas ievainojamību, jo vinai ir psihiski uzvedïbas traucējumi, ar mērk̦i nodot cietušo trešo valstu pilson,u atkarībā, bet pers. I. izdevās aizbēgt" [Rīgas pilsētas Vidzemes priekšpilsētas tiesas saīsinātais spriedums].

Pārsvarā vervētāju argumenti ir balstīti uz cilvēku pamatvajadzībām - pēc ikdienas iztikas, drošības, piederības, cieṇas. Tādēl piedāvājums, kas ietver nepiepildīto vajadzību apmierināšanu, kḷūst tik nozīmīgs, ka risku izvērtēšana vairs nav iespējama. Darba vai peḷnas piedāvājums ir svarīgs gan nabadzības gadījumā, gan tad, ja tā ir iespēja palīdzēt 
savai ǵimenei [Patvērums "Drošā māja”]. Kā piemērs upura ekonomiskajai ievainojamībai ir šāds gadījums: D. bija devusies strādāt uz Vãciju, kur solīja darbu bārā. Vācijā darba devējs, izmantojot sievietes ievainojamību - nespēju nodrošināt sev iztiku un pārvarēt valodas barjeru -, jauno sievieti iesaistīja seksuālu pakalpojumu sniegšanā klubā. D. bija dzìvojusi un ieguvusi pamatskolas izglìtību Latvijas mazpilsētā. D. nebija vienīgais bērns ǵimenè. Vecāki strādāja, bet viṇiem bija alkohola atkarība un nekad nebija pietiekami laika, ko veltìt bèrniem [Centrs Marta, 2018].

Apkopojot kriminologiskās izpētes datus, var secināt, ka ir šādas potenciālās riska grupas, kas visbiežāk pakḷautas cilvēku tirdzniecības viktimizācijas riskam: cilvēki ar zemu izglīīibas līmeni; bezdarbnieki, darba meklētāij; personas ar kredītsaistībām; personas ar zemiem un neregulāriem ienākumiem; sievietes (pārsvarā 18-40 gadu vecas); vientuḷās mātes; prostitūtas; personas, kuras jau iepriekš ir pārcietušas vardarbību (viṇas ir neaizsargātākas pret turpmāku ḷaunprātīgu izmantošanu, jo traumējošā notikuma ietekme parasti ir ilgstoša un sarežǵîta); jaunietes vecumā līdz 25 gadiem; bērni un pusaudži no sociālā riska giimenēm; personas no daudzbērnu un maznodrošinātām ğimenēm; bāreṇi, ielu bērni; etniskās minoritātes. Ir arī gimenes, kuras bērnu uztver kā lietu vai kaut ko traucējošu. Šajos gadījumos vecāki liedz bērnam savstarpējas attiecības un audzināšanu, nel̦auj viṇam integrēties gimenē, un bērns, iespējams, pat nesaṇem nepieciešamo uzturu. Vecāki sūta bērnus arī ubagot vai iegūt uzturu noziedzīgā ceḷā [Viano, 1976].

\section{Cilvēku tirdzniecības vispārējās tendences pasaulē un Latvijā}

Cilvēku tirdzniecībai tās specifiskā rakstura dēḷ ir augsts latentātes līmenis. Grūtības rada cilvēku tirdzniecības gadỉjumu atpazišana, upuru konstatēšana un identificēšana, tādēḷ nozieguma atklāšana un izmeklēšana ir komplicēta. Var piekrist atzinnai, ka cilvēku tirdzniecība var notikt tikai sabiedrības, profesionālās un akadēmiskās vienaldzības atmosfērā [Farley et al., 2004]. Jāatzīst, ka statistikas pieejamība un ticamība šobrīd Latvijā ir nepilnīga. Registrētās kriminālās statistikas dati ir tikai aisberga redzamā daḷa; Latvijā ik gadu tiek reǵistrēts neliels noziedzīgo nodarījumu skaits, kas ir saistīts ar cilvēku tirdzniecību (sk. 1. att.).

Viktimologiskos pētījumos konstatēts, ka neziņošana par noziedzīgiem nodarījumiem Latvijā ir plaša parādība - neziṇo no 40 līdz 80 \% cietušo (atkarībā no noziedzīgā nodarījuma veida). Joprojām ir aktuāla satraucoša tendence, ka tiek identificēts liels skaits upuru, uzsākta izmeklēšana, taču līdz tiesai nonāk neliels skaits krimināllietu par cilvēku tirdzniecību [Iekšlietu ministrija, 2019a].

Augsto cilvēku tirdzniecības latentātes līmeni ataino dažādi statistikas dati.

Saskaṇā ar ASV Valsts departamenta (U. S. Department of State) datiem visā pasaulē 27 miljoni upuru (sievietes, vīrieši un bērni) tiek pakḷauti cilvēktirdzniecībai [Victimology, 2018]. Tirdzniecības upuri nonāk lauksaimniecības darbos, slimnīcās, restorānos, mājsaimniecībās un citās nozarēs, kā arī prostitūcijā [Bernat and Zhilina, 2010]. 


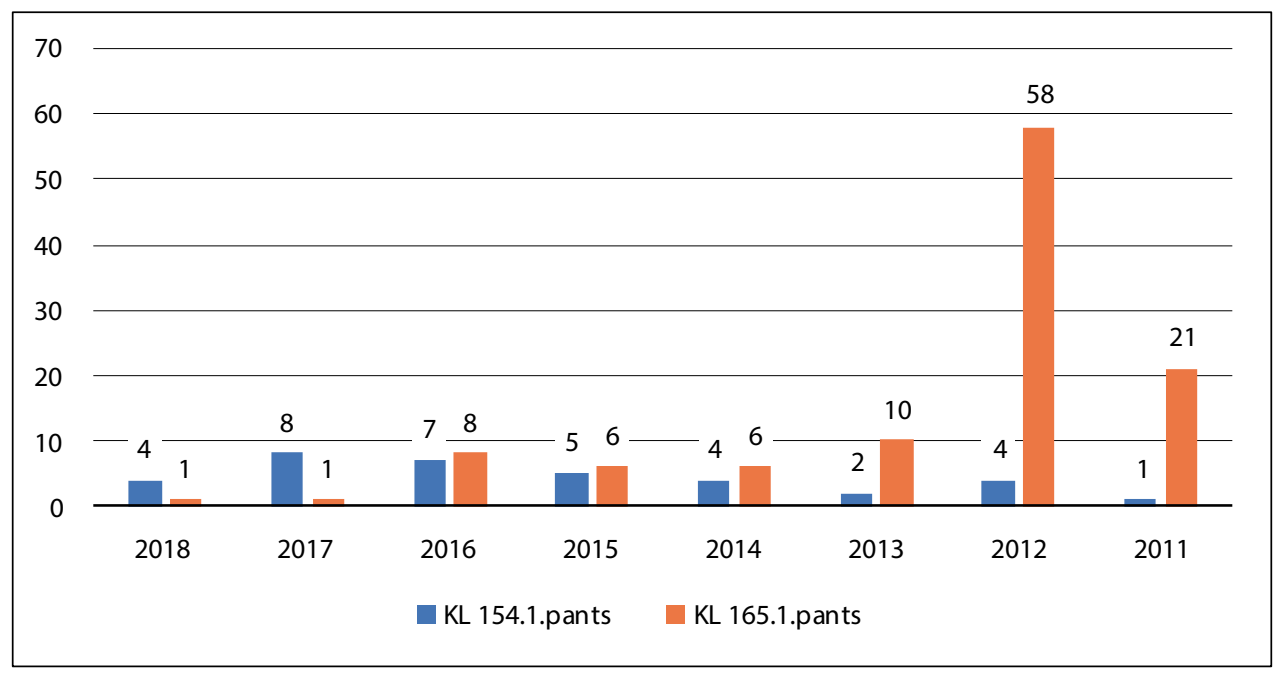

1. attēls. Ar cilvēktirdzniecību saistîtie reǵistrētie noziedzīgie nodarījumi pēc Krimināllikuma 154.1 panta un Krimināllikuma $165 .^{1}$ panta laikposmā no 2011. lìdz 2018. gadam (avots: Iekšlietu ministrijas Informācijas centra dati)

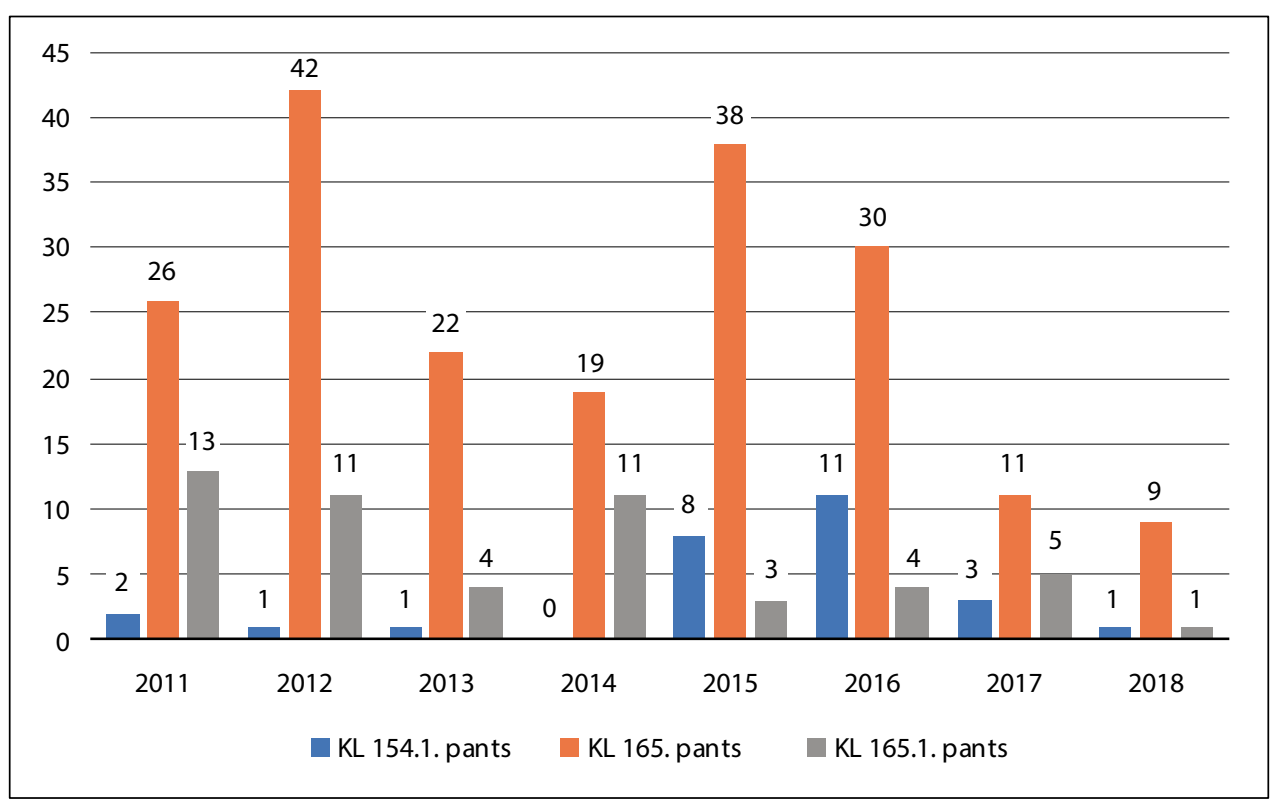

2. attēls. Ar cilvēktirdzniecību saistìto par noziedzīgiem nodarījumiem tiesai nodoto personu skaits (avots: Latvijas Republikas Prokuratūra) 
Pēc Starptautiskās darba organizācijas datiem, visā pasaulē ir 40,3 miljoni cilvēku tirdzniecības upuru. 2017. gadā starptautiskā ziņojumā konstatēts, ka 40 miljoni cilvēku ir upuri cilvēku tirdzniecībā, apmēram 25 miljoni ir iesaistīti piespiedu darbā, savukārt 15 miljoni - piespiedu laulībā; to apliecina dati par piespiedu darbu un piespiedu laulību [International Labour Office, 2017].

ANO Narkotiku un noziedzības biroja (UNODC) dati parāda, ka 51 \% identificēto upuru ir sievietes, $28 \%$ - bērni un $21 \%$ - vīrieši; $72 \%$ upuru, kuri iesaistīti seksa industrijā, ir sievietes; $63 \%$ identificēto cilvēku tirgotāju ir vīrieši un 37\% - sievietes; $43 \%$ upuru tiek tirgoti valsts ietvaros [The United Office on Drugs and Crime, 2018]. Starptautiskās migrācijas organizācijas dati liecina, ka Baltijā katru gadu par cilvēku tirdzniecības upuriem kḷūst aptuveni 2000 cilvēku.

Centra Marta gada pārskatā norādīts, ka 2017. gadā tajā vērsās 30 cilvēku tirdzniecībā cietušas personas. Palīdzība tika sniegta arī personām, kuras ir fiktīvo laulību upuri un vienlaikus cietušas arī seksuālajā un darba ekspluatācijā, kā arī personai, kura tikusi turēta parādu verdzībā. Valsts finansētais sociālās rehabilitācijas pakalpojums tika nodrošināts 10 cilvēku tirdzniecībā cietušām personām, kuras atzītas par upuriem. Visas par upuriem atzītās personas bija Latvijā dzimušas sievietes, divas no viṇām - nepilngadīgas [Centrs Marta, 2018]. Saskaṇā ar Iekšlietu ministrijas publicēto pārskatu par cilvēku tirdzniecības novēršanas un apkarošanas rezultātiem 2018. gadā tika konstatēti 23 cilvēku tirdzniecības upuri: 6 - seksuālai izmantošanai, 12 - darbaspēka ekspluatācija, 5 - fiktīvās laulības, 12 upuri bija sievietes un 11 - vīrieši; visi upuri bija Latvijas valstspiederīgie vecumā virs 18 gadiem [Iekšlietu ministrija, 2019b].

Aktuāla problēma ir bērnu tirdzniecība. Aptuveni pieci miljoni bērnu visā pasaulē atrodas verdzībā un tiek izmantoti daudzos veidos, piemēram, iesaistīti bruṇotajos konfliktos (ne tikai karavīri, bet arī kā pavadoṇi; meitenes - arī kā karavīru "sievas") un piespiedu laulībā. Saskaṇā ar UNICEF datiem 11 \% gadỉjumu no visā pasaulē konstatētajām piespiedu laulībām ir iesaistītas meitenes, kuras nav sasniegušas 15 gadu vecumu. Aprēḳināts, ka līdz 2020. gadam šo meiteṇu skaits var pārsniegt 140 miljonus [UNICEF]. Bērni tiek nodarbināti dažādos darbos; salīdzinot ar pieaugušajiem, bērni ir vieglāk kontrolējami, nepieprasa augstāku atalgojumu vai labākus darba apstākḷus [Antislavery]. Ne mazāk problemātiska ir bērnu piespiedu iesaiste noziedzīgos nodarījumos. Piemēram, cietušie bērni tiek piespiesti iesaistīties noziedzīgu nodarījumu izdarīšanā ielās (street crime) - kabatzādzībās, sominuu izraušanā, zādzībās no veikaliem, kā arī ubagošanā [HM Government, 2014].

Tradicionāli cilvēka tirdzniecības mērḳis ir indivīda ekspluatācija materiāla labuma iegūšanai. Ekspluatācijas nolūks ir personas iesaistǐšana prostitūcijā vai cita veida seksuālā izmantošanā; piespiešana veikt darbu vai sniegt pakalpojumu; piespiešana izdarīt noziedzīgus nodarījumus; turēšana verdzībā vai citās tai līdzīgās formās (parādu verdzība, dzimtbūšana vai personas cita veida piespiedu nodošana citas personas atkarībā, turēšana kalpībā); personas audu vai orgānu nelikumīga izṇemšana [European Commission, 2018]. Arī fiktīvās laulības ir viens no ekspluatācijas veidiem. Piemēram: pers. C. personu grupā 
l̦aunprātīgi nodrošināja personu ar iespēju likumigi iegūt tiesības uzturēties Latvijas Republikā, citā Eiropas Savienības dalībvalstī, Eiropas Ekonomikas zonas valstī vai Šveices Konfederācijā (izdarīja noziedzīgu nodarïjumu, kas paredzēts Krimināllikuma $285 .{ }^{2}$ panta otrajā daḷa [Rīgas pilsētas Vidzemes priekšpilsētas tiesas saīsinātais spriedums].

Iesaiste piespiedu noziedzībā var izpausties piespiešana zagt (no tirdzniecības vietām, dzīvokḷiem, mājām, veikt kabatzādzības), krāpt, laupīt; piedalīities narkotisko vielu nelegālajā apritē. Saskaṇā ar Lielbritānijā iegūtiem datiem 2011. gadā hašiša audzēšanā iesaistīti 30 upuri, 2012. gadā - 69. Turklāt cilvēku tirdzniecības upuris var izdarīt noziedzīgus nodarïjumus, kuri nav dạ̦a no ekspluatācijas elementa, bet gan ir saistīti ar viña migranta statusu [Muraszkiewicz, 2019].

Cilvēku tirdzniecība ir ne tikai daudzšḱautņains, bet arī pastāvīgi mainīgs fenomens un nopietns organizētās noziedzības veids. Cilvēku tirgotāju modus operandi (patstāvīga vai ierasta metode vai paṇēmiens) nepārtraukti attīstās. Noziedznieka modus operandi var palïdzēt viṇu identificēt un arī noteikt saikni starp noziegumiem. Vairākos ES ziṇojumos ir atzìts, ka ES ir jārisina saikne starp cilvēku tirdzniecību un citiem noziegumiem, tostarp migrantu kontrabandu, terorismu, korupciju, narkotiku tirdzniecỉbu, kibernoziegumiem un seksuālu izmantošanu internetā, tādu materiālu ražošanu, kas ir saistīti ar seksuālu vardarbību, bērnu seksuālo izmantošanu, finanšu noziegumiem, krāpšanu, nelikumīgām darbībām ar kredītkartēm [Europol, 2016, 2017].

\section{Cilvēku tirdzniecības faktoru kriminoloǵiskais raksturojums}

Faktoru (cēloṇu) atklāšana ir pirmais un galvenais solis, lai specifiski un efektīvi uz tiem iedarbotos un neitralizētu kaitīgās sekas.

Kriminologiijā izšḳir:

- noziedzības kā sociālas parādības faktorus (cēloṇus). Noziedzības faktori ir vispārsociālās un individuālās (sociālās un biologiskās) cilvēka dabas un apziņas izpausmes kopums, kurā šis komplekss pretdarbojas sabiedriskajām attiecībām un determinē gan noziedzīgu uzvedību, gan noziedzību kopumā [Avanesov, 2006];

- atsevišķ nu noziedzīgu nodarījumu grupu cēloṇus;

- konkrētu noziedzīgu nodarījumu cēloṇus. Konkrēta noziedzīga nodarījuma k̦ēdē ir savijušies dažādi apstākḷi (sociālie, ekonomiskie, psiholog̣iskie, politiskie, tiesiskie, tikumiskie u. c.), kuru dēl persona nolemj izdarìt noziedzīgu nodarījumu. Noziedznieka personība ar tā apziṇu, gribu un vēlmēm ir galvenais noziedzīga nodarījuma cēloṇu un veicinošo apstākḷu k̦ēdes posms. Turklāt jāṇem vērā arī upura personības ievainojamïbas pakāpe.

Sociālie un ekonomiskie apstākḷi cilvēku tirdzniecības upuru izcelsmes valstīs veicina cilvēku tirdzniecību, ietekmē cietušos un arī tirgotājus, un tos sauc par rosinošajiem faktoriem (push factors). Raksta autori norāda, ka tiem ir negatīva viktimologiska ietekme, radot potenciālā upura ievainojamību un neaizsargātību, ko izmanto noziedznieks. 
Potenciālie cilvēku tirdzniecības upuri ir piedzīvojuši nelabvēlīgus personiskos apstākḷus, izglīīibas trūkumu, augstu bezdarba un zemu dzīves līmeni, dzimumu diskrimināciju vai nevienlīdzību darba tirgū; viṇi var piedzīvot cilvēktiesību pārkāpumus un l̦aunprātīgas situācijas vai ir spiesti bēgt no konflikta zonām.

Ir vairāki faktori, kas dažas valstis cilvēku tirdzniecībai dara pievilcīgākas nekā citas. Šie faktori nosaka cilvēku tirdzniecības upuru mērḳa valstu sabiedrisko, juridisko, politisko un ekonomisko kontekstu, un tie var kalpot kā izraisošie faktori (pull factors). Šajā gadijjumā tiem ir kriminogēns raksturs, kas veicina personas motivāciju (tieksmi) izdarīt nodarījumu. Visbiežāk sastopamie izraisošie faktori ir augsti dzīves standarti un nodarbinātības iespējas; pieaugošais pieprasījums pēc lēta darbaspēka pakalpojumiem; visā ES izveidotās ārvalstu pilsoṇu diasporas kopienas; atšḳirības dalībvalstu tiesību aktos [Europol, 2016].

Cita starpā sarežğìti un savstarpēji saistīti faktori, piemēram, sistemātiska un strukturāla diskriminācija, cilvēktiesību pārkāpumi, nabadzība, nevienlīdzība, korupcija, vardarbīgs konflikts, zemes konfiskācija, izglìtības trūkums, bezdarbs un neefektīivi darbaspēka migrācijas noteikumi, palielina personu neaizsargātību pret ekspluatāciju un launprātīgu izmantošanu, jo viniem ir ierobežotas izvēles iespējas un resursi [Eiropas Parlaments, 2016].

Zinātniskajā literatūrā ir pieņemts nodalīt ārējos jeb objektīvos un iekšējos jeb subjektīvos viktimogēnos faktorus, kas ietekmē noziedzību [Репецкaя, 2009], un šo iedalijumu var attiecināt uz cilvēku tirdzniecību. Ārējie viktimogēnie faktori ir mikrovides un makrovides ietekme, respektīivi, pirmskriminālā situācija, objektīvie apstākḷi, kas rodas tieši pirms noziedzīga nodarījuma vai nodarījuma izdarī̌̌anas brīdī. Tie nav saistīti ar upura viktimizāciju un upura uzvedību. Iekšējie viktimogēnie faktori ir saistìti ar upura identitāti, upura personības veidošanās apstākḷiem un uzvedību raksturojošiem cēloṇiem.

Tātad no kriminologiskā viedokḷa cilvēku tirdzniecība ir determinēta sociālo, ekonomisko, morālo un ètisko faktoru kopumā korelācijā ar augstu kriminālo profesionālismu un daudzveidīgiem kriminālās rīcības veidiem, lai pakḷautu personu verdzības apstākḷiem. Cilvēku tirdzniecību var veicināt daudzveidīgu cēloṇu un apstākḷu kopums - bezdarbs, vāja sabiedrības ekonomiskā un sociālā struktūra, kultūras iezīmes, sapnis par labāku dzīivi; vardarbība pret sievietēm un bērniem, bruṇoti konflikti.

Tajā pašā laikā jāṇem vērā, ka pastāv vairāki faktori un apstākḷi, kas rada šḳēršlı cilvēku tirdzniecības gadījumu konstatēšanai un upura identificēšanai; šie faktori un apstākḷi ir saistīti ar:

- nodarījuma subjekta darbībām - aktīvu noziedzīgās vides pretdarbību. Pārsvarā to organizē un kontrolē organizētā grupa, lai iegūtu naudas līdzekḷus. Šo darbību veikšanā iesaistās vairākas personas, katrai ir savi pienākumi un uzdevumi. Šiem nodarïjumiem ir pārrobežu raksturs, ir daudz iesaistīto upuru;

- upura personību - valodas vai kultūras barjeru; cietušās personas informētību vai izglītības trūkumu; upura izolāciju; lielākām bailēm un drošỉbas aizskārumu; ierobežotām iespējām ziṇot par nodarỉjumu; 
- sabiedrības attieksmi un informētỉbu - sabiedrības aizspriedumiem pret upuri; salīdzinoši lielākām upura vajadzībām; nepietiekamiem resursiem un atbalsta pakalpojumiem.

Vēl viens problēmas aspekts ir tas, ka cilvēku tirdzniecības upuri reti sevi pozicionē kā noziedzīga nodarījuma upuri. Pastāv indikatori jeb "sarkanās iezīmes" (anglu val. red flags), kas var norādìt uz iespējamo cilvēku tirdzniecības upuri. Upuri var identificēt pēc situācijas, dzīvesstāsta un izturēšanās [Logan, Walker E Hunt, 2009]. Šo kategoriju cietušajiem ir nepieciešama daudznozaru palīdzība, lai risinātu traumatisko ietekmi un nodrošinātu upura vajadzības.

Tã kā cilvēku tirdzniecība globāla problēma, palīdzības sniegšana cietušajām personām ir specifiska un problemātiska vairāku apstākḷu dẹl. Personām, kuras ir kḷuvušas par cilvēku tirdzniecības upuriem, bieži pietrūkst zināšanu un prasmju apzināt un novērtēt riska pakāpi, kritiski izvērtēt cilvēku tirgotāju sniegto informāciju, kā arī paredzēt un nepiel̦aut kaitīgas sekas. Tādēl pozitīva personības pamatnostādne ir spēja kritiski un atbilstoši novērtēt situāciju un izvēlēties pareizo uzvedības modeli.

\section{Secinājumi}

Cilvēku tirdzniecība ir komplekss globāls fenomens, kuru novērst var tikai šādu visaptverošu pasākumu kopumā:

- transformējot sociālo vidi;

- pārveidojot noziedznieka personību;

- neitralizējot noziedzīgās izpausmes;

- iedarbojoties uz upura personibu.

Tātad cilvēku tirdzniecības novēršana ir daudzlīmeṇu tiesisko ietekmēšanas līdzekḷu sistēma. Prevencijas pasākumiem ir jāiedarbojas uz plašām sabiedrības dzīves jomām - sociālo nodrošināšanu, nodarbinātību, izglìtību, brīvā laika aktivitātēm u. c.

Nozīmīgs prevencijas uzdevums ir informēt dažādus sabiedrības slānuus par to, kā nenokḷūt vervētāju slazdos, kas ir viltīgi veidoti un dažkārt loti grūti atpazīstami.

Mūsdienās cilvēku tirdzniecỉbas novēršanas noziedzỉbas teorija un prakse nosaka ne tikai to, ka ir jāuzlabo tiesību akti, bet ir nepieciešamas arī nestandarta pieejas, tostarp tās, kuru mērḳis ir izveidot mehānismu nesen izplatīto noziegumu novēršanai un apkarošanai. Tomēr ir jāatzīst, ka, pasaulē pieaugot sociālajai nevienlīdzībai, cilvēku tirdzniecība kā sociāli tiesiska parādība eskalēsies. 


\section{Criminological Problems of Human Trafficking}

\section{Abstract}

Criminological problems of human trafficking have been considered in this article. The authors have provided insight into the problematic issues that pertain to the criminological aspects of this socio-legal phenomenon.

Human trafficking is a dynamic phenomenon that easily adapts to changing conditions. Traditionally, human trafficking has the nature of organised crime. A variety of diverse causes and conditions lead to human trafficking. Globalisation of social and economic processes is one of the driving forces of human trafficking. Thus, measures to prevent trafficking in human beings must have an impact on broad segments of society.

Keywords: human trafficking, criminological problems, criminological research, factors.

\section{Avoti un literatūra}

\section{Tiesību akti}

1. Krimināllikums. Latvijas Republikas likums: pieṇemts 17.06.1998. un stājās spēkā 01.04.1999. Latvijas Vēstnesis Nr. 199/200(1260/1261), 08.07.1998. Iegūts no: https://likumi.lv/doc. php?id=88966 [sk. 07.08.2019.].

\section{Tiesu prakse}

2. Rīgas pilsētas Vidzemes priekšpilsētas tiesas saīsinātais spriedums Kr. 1. 12507002216 (lietv. Nr. K30-0995-17/10).

\section{Literatūra}

3. Avanesov, G. A., red. 2006. Kriminologiia. Moskva (Аванесов, Г. А., реА. 2006. Криминология. Москва).

4. Bernat, F. P. \& Zhilina T. 2010. Human Trafficking: The Local Becomes Global. Women $\mathcal{E}$ Criminal Justice. 20(1-2), 2-9.

5. Farley, M., Cotton, A., Lynne, J., Zumbeck, S. et al. 2004. Prostitution, trafficking, in nine countries. In: Farley M, ed. Prostitution, trafficking and traumatic stress. Binghamton, NY: Haworth Press.

6. Glonti, G. 2004. Torgovlya lyudmi s celju seksualnoj ekspluatacii: relii i perspektivii (kriminolologicheskii analiz prostutucii, pornobiznesa i trafikinga). Tbilisi (ГАонти Г. 2004. Торговля людьми с целью сексуальной эксплуатации: реалии и перспективы (криминологический анализ проституции, порнобизнеса и трефикинга). Тбикиси).

7. Ivančiks, J. 2008. Cilvēku tirdzniecības apkarošanas aktualitātes Latvijā. Administratīvā un Kriminālā Justīcija. 3/2008(44), 36-46.

8. Logan, T. K., Walker, R. and Hunt, G. 2009. Understanding Human Trafficking in the United States. Trauma, Violence \& Abuse. 10(1), 3-20.

9. Muraszkiewicz, J. M. 2019. Protecting Victims of Human Trafficking from Liability. The European Approach. Palgrave Macmillan. 
Andrejs Vilks, Aldona Kipāne. Cilvēku tirdzniecība:

kriminologiskās problēmas

10. O'Connell Davidson, J. 2010. New slavery, old binaries: human trafficking and the borders of "freedom". Global Networks. 10(2), 244-262. Iegūts no: https://glc.yale.edu/sites/default/files/ pdf/new_slavery_old_binaries.pdf [sk. 18.08.2019.].

11. Repeckaja, A. L., red. 2009. Viktimologicheskaja harakteristika regionalnoj prestupnosti i ee preduprezdenie. Moskva: Akademia (Репецкая, А. А. 2009. Виктимологическая характеристика региональной преступности и ее предупреждение. Москва: Aсаdemia).

12. Viano, E. 1976. Victims and Society. Washington, DC: Visage.

13. Vilks, A. 2002. Cilvēku un viṇu orgānu tirdzniecība: kriminolog̣iskās, politiskās un sociālās problēmas. Ieskats XXI gadsimta reālijās. Rīga: Baltijas antikriminālais un antiteroristiskais forums.

14. Walsh, A. and Jorgenson, C. 2018. Criminology: The Essentials. $3^{\text {rd }}$ ed. Sage Publications, Inc.

15. Zadorozniy, V. I. 2005. Viktimologicheskaya profilaktika prestupleniy: organizaciono upravlecheskii i pravovie aspekti. Moskva (Задорожный, В. И. 2005. Виктимологчческая профилактика преступлений: организачионно-управленческий и правовой аспекты. Москва).

\section{Interneta resursi}

16. Anti-slavery. What is modern slavery? Iegūts no: https://www.antislavery.org/slavery-today/ modern-slavery/ [sk. 11.05.2019.].

17. ASV Vēstniecība Latvijā. 2018. ASV Valsts Departamenta ziṇojums "Par cilvēku tirdzniecības novēršanu". Iegūts no: https://lv.usembassy.gov/lv/our-relationship-lv/policy-history-lv/trafficking-in-persons-lv/ [sk. 07.08.2019.].

18. ASV Vēstniecība Latvijā. 2019. ASV Valsts Departamenta ziṇojums "Par cilvēku tirdzniecības novēršanu". Iegūts no: https://lv.usembassy.gov/lv/our-relationship-lv/policy-history-lv/trafficking-in-persons-lv/ [sk. 14.08.2019.].

19. Centrs Marta. 2018. Gada pārskats. Iegūts no: http://www.marta.lv/par-martu/gada-parskati [sk. 13.05.2019.].

20. Eiropas Parlaments. 13.06.2016. Ziṇojums par cilvēku tirdzniecības apkarošanu ES ārējās attiecībās (2015/2340(INI)). Iegūts no: www.europarl.europa.eu/doceo/document/A-8-2016-0205_ LV.html [sk. 07.08.2019.].

21. European Commission. Lancaster University. Data collection on trafficking in human beings in the EU. Final report - 2018. Iegūts no: https:/ec.europa.eu/home-affairs/sites/homeaffairs/ files/what-we-do/policies/european-agenda-security/20181204_data-collection-study.pdf [sk. 17.08.2019.].

22. Europol. 2016. Trafficking in Human Beings in the EU. Situation Report. Iegūts no: https://www. europol.europa.eu/publications-documents/trafficking-in-human-beings-in-eu [sk. 17.08.2019.].

23. Europol. 2017. European Union Serious and Organized Crime Threat Assessment. Iegūts no: https:/www.europol.europa.eu/activities-services/main-reports/european-union-serious-andorganised-crime-threat-assessment-2017 [sk. 17.08.2019.].

24. HM Government. 2014. Modern Slavery Strategy. Iegūts no: https://www.antislaverycommissioner.co.uk/media/1079/modern_slavery_strategy_final_dec2015.pdf [sk.12.05.2019.].

25. Iekšlietu ministrija. 2019a. Konference "Cilvēku tirdzniecība - noziegums ar pārāk maz notiesājošiem spriedumiem un pārāk daudz upuriem”. Iegūts no: http://www.cilvektirdznieciba.lv/lv/ cilveku-tirdznieciba---noziegums-ar-parak-maz-notiesajosiem-spriedumiem-un-parak-daudzupuriem/223 [sk. 12.05.2019.].

26. Iekšlietu ministrija. 2019b. Cilvēku tirdzniecības novēršanas un apkarošanas rezultāti 2018. gadā. Iegūts no: http://www.iem.gov.lv/lat/aktualitates/?doc=41476 [sk. 06.08.2019.]. 
27. Iekšlietu ministrijas Informācijas centrs. Kriminālā statistika. Iegūts no: http://www.ic.iem.gov. lv/node/109 [sk. 13.05.2019.].

28. International Labour Office. 2017. Global Estimates of Modern Slavery: Forced Labour and Forced Marriage. Iegūts no: http://www.ilo.org/wcmsp5/groups/public/--dgreports/---dcomm/ documents/publication/wcms_575479.pdf [sk. 13.05.2019.].

29. Latvijas Republikas Prokuratūra. Pārskats par prokuratūras 2018. gada darba rezultātiem. Iegūts no: http://www.prokuratura.gov.lv/lv/noderigi/gada-parskati [sk. 10.05.2019.].

30. Patvērums "Drošā māja". Speciālistu padomi. Iegūts no: http://www.patverums-dm.lv/lv/specialistu-padomi [sk. 11.05.2019.].

31. Starptautiskā migrācijas organizācija. 2006. Cilvēku tirdzniecība - izpratne, problēmas, risinājumi. Rokasgrāmata sociālajiem darbiniekiem. Iegūts no: http://cilvektirdznieciba.lv/data/Files/ macibspekiem/CT.pdf [sk. 07.08.2019.].

32. The Minderoo Foundation. We Can End Modern Slavery in our Generation. Iegūts no: https:// www.minderoo.com.au/walk-free/?utm_medium=301\&utm_source=www.walkfreefoundation. org [sk. 14.08.2019.].

33. The United Office on Drugs and Crime. Annual Report. Covering activities during 2018. Iegūts no: https://www.unodc.org/documents/AnnualReport/Annual-Report_2018.pdf [sk. 12.05.2019.].

34. UNICEF. Child marriage. Iegūts no: https://www.unicef.org/media/files/Child_Marriage_ Report_7_17_LR..pdf [sk. 12.05.2019.].

35. Victimology. Exploring the Experience of Victimization. Introduction to Criminology. Section III. Iegūts no: https://us.sagepub.com/sites/default/files/upm-binaries/90401_Section_Three_ Victimology_Exploring_the_Experience_of_Victimization.pdf [sk. 12.05.2019.]. 
https://doi.org/10.25143/socr.13.2019.1.063-075

\title{
Atbildība par nepatiesas informācijas sniegšanu apdrošinātājam apdrošināšanas līguma ietvaros
}

\author{
Jeḷena Alfejeva \\ Rìgas Stradiṇa universitāte, Juridiskā fakultāte, Latvija \\ alfejeva@inbox.lv
}

\section{Kopsavilkums}

Šajā rakstā aplūkots jautājums par atbildību Latvijas apdrošināšanas tiesībās gadījumos, kad apdrošināšanas līguma ietvaros apdrošinātājam tiek sniegta nepatiesa informācija. Tiek sniegts ieskats par apdrošināšanas līguma līdzēju mērḳiem un pienākumiem, raksturota apdrošināšanas līguma būtība tā, lai izprastu iemeslu, kādēḷ apdrošinātājam jāsaṇem informācija par apdrošināmo objektu un riskiem. Apskatīta arī uberrimae fidei principa nozīme apdrošināšanas attiecībās. Vēl šeit ir aplūkots jautājums par atbildības noteikšanu un nepatiesas informācijas sniegšanas sekām. Raksta nobeigumā ir îss kopsavilkums par risinājumiem apdrošināšanas attiecību regulēšanas uzlabošanai Latvijā saistībā ar aplūkotajām problēmām.

Raksta izstrādē galvenokārt tika izmantota analīzes un sintēzes metode, zinātniskās indukcijas un dedukcijas metode, salīdzinošā metode, kā arī novērošana.

Atslēgvārdi: apdrošināšanas līgums, uberrimae fidei, līgumiskā atbildība.

\section{levads}

Kaut arī apdrošināšanas līgums ir privāttiesisks darījums, Latvijas tiesību doktrīnā apdrošinātāja pienākums izmaksāt apdrošināšanas atlīdzỉbu ir izcelts kā publiski nozīmīgs un par to daudz tiek diskutēts tiesiskā regulējuma pilnveidošanas kontekstā $[25,107-117]$.

Savukārt jautājums par apdrošinātāju klientu informācijas izpaušanu pirms līguma noslēgšanas un līguma darbības laikā tiek apskatīts minimāli, galvenokārt uberrimae fidei principa kontekstā, turklāt uzsvaru liekot uz apdrošinātāja pienākumu rīkoties labticīgi. 
Praksē ir bijuši vairāki gadījumi, kuros apdrošinātāja pienākumu neizpilde raisa nopietnas bažas par labticību, tomēr pats uberrimae fidei princips, veidojot attiecīgu legālo doktrīnu, primāri bija domāts klientu informācijas atklāšanai apdrošinātājiem ar konkrētu mērḳi, kas iekḷauj klientu finansiālo interešu aizsardzību.

Apdrošinātājam nav informācijas par apdrošināmajiem riskiem un apdrošināšanas objektu, pirms klients to nav sniedzis, tādējādi darījuma pusēm, slēdzot un pildot apdrošināšanas līgumu, pieejamā informācija ir asimetriska [27].

Tādēl, paredzot iespējamās problēmas, apdrošināšanas līgumiem tiek piemērots informācijas pilnīgas izpaušanas jeb vispārākās labās ticības princips, ko sauc par uberrimae fidei principu.

Šai ziṇā svarīgi ir apzināties, ka apdrošināšanas komersantam (apdrošinātājam), ar līgumu (komercdarijumu) uzṇemoties klienta riska finansiālās sekas, jāsaṇem atbilstoša atlīdzība par sniedzamajiem pakalpojumiem - to apdrošināšanas tiesībās sauc par apdrošināšanas prēmiju. Apdrošināšanas prēmijai jābūt noteiktai tādā apmērā, lai nodrošinātu līgumsaistību izpildi un nosegtu visus iespējamos apdrošinātāja izdevumus. Tādējādi apdrošinātājam jāspēj atbilstīgi novērtēt gan riska iestāšanās varbūtību, gan tā iespējamās sekas, un tieši klienta informācija tam ir primārais avots. Turklāt pašiem klientiem nebūtu izdevīgi, ka apdrošinātājs veiktu pirmslīguma pārbaudes, lai pārliecinātos par klienta sniegtās informācijas patiesumu un pilnīgumu, jo šādu pārbaužu izdevumi būtu jāsedz klientam papildus tiem izdevumiem, kas tieši attiecināmi uz risku segumu kā apdrošināšanas atlīdzības avotu.

Raksta mērḳis ir iepazīstināt lasītāju ar apdrošinājuma ṇēmēja un apdrošinātā informācijas atklāšanas pienākuma analīzi, ar šā pienākuma neizpildes civiltiesiskajām sekām, kā arī ieskicēt Latvijā pastāvošās problēmas saistībā ar to.

Pētījuma teorētiskā bāze ir Latvijas un citu valstu zinātnieku atzinumi par apdrošināšanas tiesībām, normatīvā bāze ir tiesiskais regulējums mūsu valstī. Raksta izstrādē tika izmantota analīzes un sintēzes metode, zinātniskās indukcijas un dedukcijas metode, kā arī novērošana.

\section{Apdrošināšanas līguma pušu mērḳi un pienākumi}

Apdrošināšana balstās uz sarežgitām līgumiska rakstura attiecībām starp apdrošinātāju, apdrošinājuma n̦ēmēju, apdrošināto un citiem apdrošināšanas līguma dalībniekiem, un tās mērḳis ir mazināt iespējamo nākotnes notikumu negatīvās finansiālās sekas, kaut arī visas iespējamās sekas apdrošinātais nevar novirzìt uz apdrošinātāju.

Apdrošināšanas attiecības balstās uz līgumu, kurā līdzēji ir pretējās puses. Tātad vienam līdzējam ir tiesības, otram attiecīgi - pienākumi.

Kaut arī sākotnēji liekas, ka apdrošināšanas līgums ir pavisam ỉpašs un no tā izrietošās attiecības nevar tikt apskatītas līdzīgi kā tās, kuras izriet no komercdarījuma, tomēr jāṇem vērā, ka pats apdrošinātājs ir komersants, un apdrošināšanas līgums nav un nevar būt kas cits kā komercdarījums, proti, līgums par pakalpojumu sniegšanu par atlīdzību (apdrošināšanas prēmiju). 
Protams, apdrošināšanas pakalpojums ir īpatnējs, tādēḷ apdrošināšanas līgumam tiek izvirzìtas papildu prasības, kas noteiktas ar imperatīvajām tiesību normām, vienlaikus ievērojot vispārējo darījumu brīvības principu.

Attiecībā uz līdzēju savstarpēju informācijas atklāšanu apdrošināšanas līgumam tiek izvirzītas nopietnākas prasības nekā lielākajai daḷai citu līgumu. Apdrošināšanas līgums pusēm uzliek saistības, kuras balstās uz labticību augstākajā pakāpē (uberrimae fidei), tomēr nekādā ziṇā nav tā, ka jebkuras apdrošināšanas attiecības tiek uzskatìtas par pilnīgi uzticamām savstarpējām attiecībām. Uberrimae fides princips apdrošināšanas attiecībās nepārveido līdzēju antagonistisko attiecību būtību un nevar arī tikt izmantots, lai nonāktu līdz uzticamām savstarpējām attiecībām, tomēr šis princips palīdz risināt svarīgus līdzēju resursu optimizācijas uzdevumus.

\section{Uberrimae fidei principa nozīme apdrošināšanas attiecībās}

Citās civiltiesību nozarēs nav tik izteikta pienākuma izpaust informāciju, kas varētu ietekmēt otra darījuma dalībnieka lēmumu noslēgt līgumu, kā tas ir apdrošināšanas tiesībās. Apdrošināšanas tiesībās šāds princips pastāv, un juridiskajā doktrīnā to apzīmē ar terminu latinnu valodā uberrimae fidei jeb vispārākajā labticībā. Noslēdzot apdrošināšanas līgumu, apdrošinājuma n̦ēmējam (dažos gadījumos arī apdrošinātajam) ir pienākums sniegt apdrošinātājam visas viṇu rīcībā esošās ziṇas par apdrošināmo risku. Šis princips atspoguḷots arī Latvijas tiesību doktrīnā. Uberrimae fidei principa būtỉbas skaidrojumu var atrast gan Latvijas tiesu praksē [9; 11], gan Eiropas Savienības Tiesas praksē - generāladvokātes Eleanoras Šarpstonas (Eleanor Sharpston) secinājumu 64. punktā lietā C-51/13 (Nationale-Nederlanden Levensverzekering Mij NV pret Hubertus Wilhelmus van Leeuwen) ir norāde, ka uberrimae fidei ir dažās ES tiesību sistēmās pastāvošais princips - generālklauzula vai nerakstìta valsts tiesību norma, kuru piemēro apdrošināšanas līgumiem, - tomēr tā specifiskā darbība un katrai darījuma pusei noteikto pienākumu skaidrības, precizitātes un paredzamības līmenis ir atkarīgs no iesaistītās konkrētās tiesỉbu sistēmas [12].

Pirmsākumā uberrimae fidei princips tika definēts vispārējās tiesībās, to piemērojot klienta sniegtajai informācijai apdrošināšanas līgumos, bet vēlāk tas attīstijās kā vispārējs apdrošināšanas tiesību princips [19].

Uberrimae fides princips nozīmē, ka apdrošināšanas līguma līdzējiem jārīkojas labticīgi, atklājot informāciju par visiem būtiskajiem faktiem saistībā ar apdrošināšanas piedāvājumu. Šis ir pretstats caveat emptor (piesardzības) principam, saskaṇā ar kuru pircējs nevar atgūt zaudējumus no pārdevēja par pirkuma objekta trūkumiem, ja vien pārdevējs nav apzināti slēpis defektus vai citādi sniedzis būtiskus maldinošus apgalvojumus [22, 79-132]. 
Vēsturiski pirmais informācijas atklāšanas principu apdrošināšanas līgumā definēja Mensfīldas grāfs (Lord Mansfield) 1766. gadā tiesvedībā Kārters pret Bēmu (Carter v Boehm):

"Apdrošināšana ir pieṇēmuma līgums. İpašus faktus, pēc kuriem var izskaitḷot nejaušỉbas risku, parasti zina tikai apdrošinātais: apdrošinātājs uzticas viṇa sniegtajām ziṇām un pieṇem, ka apdrošinātais neslēpj kādus viṇam zināmus apstākḷus, lai maldinātu apdrošinātāju, liekot tam domāt, ka šādu apstākḷu nav. Labticīgi nodomi nepiel̦auj, ka tiktu slēpti apstākḷi, kuri ir zināmi, tā, lai otra puse par tiem neuzzinātu un lai saṇemtu labumu no tā, ka otra puse tic pretējam." [29]

Uberrimae fides doktrīna attīstījās vispārējās tiesībās, attiecinot līdzvērtīgu labticības prasību uz apdrošinātāju. Šobrīd šis ir Eiropas Savienības tiesībās skaidri formulēts princips par pirmslīguma informācijas atklāšanu no abām līgumslēdzējām pusēm. Tã ir apdrošinātāja vai apdrošināšanas starpnieka sniedzamā informācija par darījuma pusi, kā arī apdrošināšanas produkta informācija, kurai šobrīd unificēti paredzēts speciālais noformējums un saturs, - tas noteikts ar Eiropas Parlamenta un Padomes 2016. gada 20. janvāra Direktīvu (ES) 2016/97 par apdrošināšanas izplatīšanu (pārstrādāta redakcija), un dokuments attiecas uz EEZ [4], savukārt Latvijas tiesībās tas ir îstenots ar Apdrošināšanas un pārapdrošināšanas izplatīšanas likumu.

Informācijas atklāšanas pienākums apdrošināšanas attiecībās nozīmē, ka apdrošinātajam ir jāatklāj precīzs objekta stāvoklis un riski, ko viṇš nodod apdrošinātājam, vienlaikus apdrošinātājam ir jāpārliecinās, ka potenciālais līgums atbilst apdrošinātā prasībām un vajadzībām, kā arī tas ir saṇēmis visu nepieciešamo informāciju, lai pieṇemtu lēmumu par līguma noslēgšanu.

\section{Atbildība par nepatiesas informācijas sniegšanu apdrošinātājam Latvijas tiesībās}

Apdrošināšanas līguma noslēgšanai ir nepieciešams, lai apdrošinātājs no klienta saṇemtu informāciju apdrošināmā riska izvērtēšanai. Tāpat apdrošinātājam jāzina par izmaiṇām klienta sniegtajā pirmslīguma informācijā. Savukārt klients ir atbildīgs par to, ka šì informācija ir patiesa un pilnīga.

Apzīmējums "klients" turpmāk tiks izmantots gan attiecībā uz apdrošinājuma ñēmēju, gan apdrošināto, jo informācijas sniegšanas pienākums apdrošinātājam ir attiecināms uz abiem nosauktajiem apdrošināšanas līguma dalībniekiem vienādi (Apdrošināšanas līguma likuma 23. panta ceturtā daḷa).

Apdrošināšanas līguma likuma, kā arī likuma "Par apdrošināšanas līgumu" (bija spēkā līdz 2018. gada 31. maijam, pirms stājās spēkā Apdrošināšanas līguma likums) normās paredzētas īpašas sekas par klienta informācijas atklāšanas pienākuma neizpildi - noslēgtā apdrošināšanas līguma spēkā neesamība, kā arī atbrīvojums apdrošinātājam no pienākuma izmaksāt apdrošināšanas atlīdzību, iestājoties apdrošinātajam riskam $[2 ; 6]$. 
Jel̦ena Alfejeva. Atbildība par nepatiesas informācijas sniegšanu

apdrošinātājam apdrošināšanas līguma ietvaros

Iepriekš arī Latvijas Republikas Augstākā tiesa atzina:

“[..] nav šaubu, ka apdrošinātājam, lai izvērtētu attiecīgā riska iespējamības pakāpi, ir būtiski zināt visus ar iespējamo risku saistītos apstākḷus gan pirms līguma noslēgšanas, gan tā darbības laikā. Likumā "Par apdrošināšanas līgumu" informācijas sniegšana par apdrošināto risku ir detalizēti reglamentēta, turklāt nodalot līgumslēdzēju tiesības un pienākumus pirms līguma noslēgšanas, tā noslēgšanas un darbības laikā, kā arī paredzot atšḳirīgas tiesiskās sekas šī pienākuma neizpildes gadījumā”. [7]

Apdrošināšanas līguma likuma 7. panta pirmajā dal̦ā ir iekḷauta norma par apdrošinājuma n,ēmēja un apdrošinātā pienākumu apdrošināšanas līguma noslēgšanas gadỉjumā sniegt apdrošinātāja pieprasito informāciju par apdrošināšanas objekta stāvokli un apstākḷiem, kas apdrošinātājam nepieciešama apdrošinātā riska iestāšanās iespējamības un iespējamā zaudējuma apmēra novērtēšanai, kā arī sniegt informāciju, kas attiecas uz apdrošinātā veselības stāvokli personu apdrošināšanā un ir nepieciešama, lai noslēgtu apdrošināšanas līgumu (iepriekš līdzīga norma bija iekḷauta arī likumā "Par apdrošināšanas līgumu”).

Lai pareizi piemērotu šo normu, ir jānoskaidro, kas ir tā informācija, kuru klientam ir pienākums sniegt apdrošinātājam.

N̦emot vērā minētajā pantā paredzēto (otrajā teikumā), apdrošinātājs riska iestāšanās iespējamības un iespējamā zaudējuma apmēra novērtēšanai izmanto arī publiski pieejamo vai savā rīcībā esošo tiesiski iegūtu informāciju par apdrošināšanas objekta stāvokli un apstākḷiem. Tas nozīmē, ka publiski pieejama vai apdrošinātāja rīcībā jau esoša informācija nebūtu iekḷaujama tajā informācijas klāstā, kā sniegšana ir klienta pienākums, ja vien apdrošinātājs neuzdod skaidru jautājumu, uz kuru gaida konkrētu atbildi.

Grūti noteikt, vai klients ir pienācīgi izpildījis informācijas atklāšanas pienākumu, atbildot noraidoši uz apdrošināšanas pieteikumā uzdoto vispārīgo aicinājumu sniegt informāciju par apstākḷiem, kuri var ietekmēt apdrošinātā riska iestāšanās iespējamību un iespējamā zaudējuma apmēra novērtēšanu, bet realitātē šādi apstākḷi ir bijuši. Klients nav riska izvērtēšanas speciālists, un, ja šādi apstākḷi nav bijuši acīmredzami, no klienta nevar prasìt tādu kompetenci risku izvērtēšanā, kāda ir pašam apdrošinātājam.

Tomēr par svarīgiem apstākḷiem, kas acīmredzami ietekmē apdrošināmo risku iestāšanos vai iespējamo zaudējuma apmēru, klientam nebūtu pamata informāciju noklusēt.

Tādēḷ ir jājautā, vai tiešām apdrošinātājam nepieciešams uzdot skaidru un nepārprotamu jautājumu, uz kuru tas gaida konkrētu atbildi, un klientam nav pienākuma papildus atklāt ko tādu, par ko nepārprotami skaidrs, ka tas ietekmē risku izvērtēšanu, kura jāveic apdrošinātājam.

Piemēram, Eiropas Vērtētāju asociāciju grupas TEGoVA grāmatas "Eiropas vērtēšanas standarti” sadaḷā "Apdrošināmās vērtības un bojājumu novērtēšana" norādīts:

"Apdrošināšanas līgums ir visaugstākās labticības pakāpes (uberrimae fidei) līgums.

Ir jāizpauž jebkādi faktori, kas, iespējams, varētu ietekmēt risku/-us (neatkarīgi no tā, vai šāda informācija tiek pieprasīta). Informācijas, kas varētu ietekmēt apdrošinātāja lēmumu nodrošināt segumu, nesniegšana var ḷaut tam atteikties no līguma." [18] 
Arī daḷa zinātnieku uzsver, ka apdrošinātajam svarīgi ir atklāt visu nepieciešamo informāciju pirms līguma noslēgšanas $[15 ; 16 ; 17 ; 24 ; 26]$.

Ja klienta rīcībā ir informācija, kas nepārprotami ietekmē apdrošināmo risku iestāšanās varbūtîbu vai iespējamo zaudējumu summu, klientam ir pienākums to atklāt apdrošinātājam pat tad, ja apdrošinātājs neuzdod par to konkrētu jautājumu.

Vai klientam, atbildot uz apdrošinātāja jautājumu nepareizi, var rasties negatīvas sekas (atbildība), ja šĩ informācija nekā neietekmēja slēdzamā apdrošināšanas līguma noteikumus? Lai to konstatētu, būtu jāveic analīze par konkrētā apdrošinātāja praksi apdrošināšanas līgumu noslēgšanā, un tas var būt visai sarežgitits uzdevums. Savukārt klienta pirmslīguma informācijas vispārējie kritēriji Latvijas apdrošināšanas tiesībās nav precīzi definēti.

Tāpēc var secināt, ka klienta pirmslīguma nepatiesas informācijas sniegšana ir jāanalizē individuāli, vispirms vērtējot atbildes uz precīzi uzdotiem jautājumiem. Ja kaut viena atbilde ir bijusi nepatiesa, jāizskata jautājums par negatīvām sekām.

Tomēr šīs negatīvās sekas nevar iestāties gadījumos, ja:

- klients ir maldīijies un šĩ maldība ir attaisnojama - tas korelē ar Apdrošināšanas līguma likuma normu par vainas pakāpēm par maldinošas informācijas sniegšanu, ko gan bieži jauc ar vispārējo klienta noskan,ojumu krāpties;

- informācija, kas nav bijusi patiesa, nav būtiska vai arī var konstatēt, ka tā nekādā veidā nav ietekmējusi slēdzamā apdrošināšanas līguma noteikumus - šajā gadījumā apdrošinātājs nebūs labticīgs, ja mēgeinās izmantot šādas informācijas sniegšanu kā pamatojumu atteikumam izmaksāt apdrošināšanas atlīdzību.

Informācijas būtiskuma vērtēšanā var tikt n̦emts vērā un pienācīgi interpretēts Latvijas Apdrošināšanas līguma likuma 7. panta pirmajā dạ̦ā lietotais vārds "nepieciešama", ja analīzei ir pieejami kritēriji, pēc kuriem apdrošinātājs vadās, nosakot līguma noteikumus un apdrošināšanas prēmiju. Protams, šeit ir arī kritēriji, kuri skaidri izriet no prakses, tomēr jebkurā gadījumā no apdrošinātāja būtu sagaidāma norāde uz šo kritēriju izmantošanu.

Savukārt atbildes vērtēšanā uz atklātu jautājumu par riska apstākḷiem būtu jāṇem vērā:

- vai informācija bijusi publiski pieejama, vai nepārprotami izsecināma no citiem apdrošinātājam zināmiem faktiem;

- vai informācija ir bijusi būtiska, vai tā varēja ietekmēt slēdzamā apdrošināšanas līguma noteikumus;

- vai klients zināja šo informāciju un bija spējīgs izvērtēt tās ietekmi uz slēdzamā apdrošināšanas līguma noteikumiem.

Neliekot akcentu uz informācijas būtiskumu, Apdrošināšanas līguma likumā nepatiesas informācijas sniegšanas gadijumi tiek škikiroti atkarībā no klienta vainas pakāpes. Jāpiemin, ka vaina var tikt vērtēta saistībā ar labticīgu rīcību [14]. 
Jel̦ena Alfejeva. Atbildība par nepatiesas informācijas sniegšanu apdrošinātājam apdrošināšanas līguma ietvaros

Apdrošināšanas līguma likuma 14. un 15. pantā ir noteikts, kādas tiesiskas sekas iestājas gadījumā, ja klients ir maldinājis apdrošinātāju, sniedzot pirmslīguma informāciju. Šai ziṇā likumdevējs konsekventi ievēro nosacījumu, ka šìs sekas nav diferencētas atkarībā no informācijas būtiskuma, bet tiek šḳirotas pēc klienta vainas pakāpes (Civillikuma 1640. pants) [2;3].

Ja maldinošu informāciju klients sniedzis vieglas neuzmanības dēl (Civillikuma 1646. pants), apdrošināšanas līgums paliek spēkā un apdrošinātājs var izvairīties no saistībām izmaksāt apdrošināšanas atlīdzību, kad iestājas apdrošinātais risks, tikai gadījumā, ja pierāda, ka, zinot pareizu informāciju, nekad līgumu nebūtu noslēdzis, turpretim nepatiesas informācijas sniegšana l̦aunā nolūkā vai rupjas neuzmanības dēl (Civillikuma 1641., 1645. pants) iznīcina apdrošināšanas līguma spēku, turklāt paredzot apdrošinātājam tiesības paturēt saskaṇā ar šo līgumu samaksāto apdrošināšanas prēmiju. L̦auns nolūks, rupja un viegla neuzmanība ir Civillikumā paredzētās vainas pakāpes, un tās ir atbilstoši jāinterpretē. [3]

Latvijas civiltiesību doktrīnā tiek pausts, ka civiltiesībās vainas jēdziens un tās konstatēšana ir saistīta ar objektīviem apstākḷiem, tāpēc ir grūti nošḳirt vainu no cita objektīvi konstatējama priekšnoteikuma - prettiesiskas rīcības [23]. Tomēr jebkuras vainas formas konstatēšana, runājot par personas juridisko atbildību, jāveic, vērtējot objektīvos apstākḷus, jo nav cita mehānisma cilvēka patieso nodomu konstatēšanai.

Turpretī ir arī uzskats, ka zaudējumu atlīdzības prasījuma pamatā par saistību (līgumisko) pārkāpumu ir Civillikuma 1779. pants, kurā vaina nav paredzēta kā atbildības priekšnoteikums, tomēr Civillikuma 1774. pantā, kas jāpiemēro kopā ar 1779. pantu, kā izṇēmums paredzēti nejauši notikumi jeb apstākḷi, par kuriem parādnieku nevar vainot, un tad arī kreditoram parādnieka vaina nav jāpierāda un parādnieks var atsvabināties no atbildības, pierādot vainas neesamību jeb to, ka saistības pārkāpums ir nejauša notikuma rezultāts [28, 12-15].

Civillikuma normas un atziņas par vainas pakāpēm saistot ar klienta nepatiesas informācijas sniegšanu apdrošināšanas līgumā, var secināt, ka būtu jāuzskata, ka klients ir sniedzis apdrošinātājam nepatiesu informāciju l̦aunā nolūkā vai rupjas neuzmanības dēḷ, ja viņš zināja pareizu atbildi uz jautājumu vai varēja to noskaidrot, tomēr atbildēja nepareizi.

Turklāt klientam l̦aunā nolūkā vai rupjas neuzmanības dēḷ (kas atbilstoši Civillikuma 1645. panta otrajai dạ̦ai civiltiesisko seku ziņā pielīdzināta l̦aunam nolūkam) maldinot apdrošinātāju, sekas ir pamatoti noteiktas kā apdrošināšanas līguma spēkā neesamība un apdrošināšanas prēmijas neatmaksāšana, jo tā ir nelabticība un Civillikuma 1. panta pārkāpums, kas jebkurā gadījumā ar apzinātu klienta rīcību apgrūtina apdrošinātājam līguma slēgšanas procesu.

Jautājums gan ir par vieglas neuzmanības saturu, proti, vai viegla neuzmanība būtu jākonstatē gadījumā, ja klients ir maldījies un šì maldība ir attaisnojama? Šeit îpaši ir izcel̦ams informācijas būtiskums, kuru pierādìt par pienākumu jāuzliek apdrošinātājam. Pierādījumu vērtēšana par to gan radītu sarežǵỉjumus tiesai, tomēr ir skaidrs, ka negatīvas sekas klientam no tās nevar iestāties, ja vien apdrošinātāja lēmums par līguma noslēgšanu 
bijis pieṇemts maldības ietekmē, kas saskaṇā ar Civillikumu būtu atzīstama par tādu, kas iznīcina līguma spēku. Ja ši informācija ietekmētu tikai cenas (apdrošināšanas prēmijas) noteikšanu, tā nebūtu jāṇem vērā, jo ticami pierādīt noteiktās apdrošināšanas prēmijas lielumu nav iespējams (prēmijas noteikšana ir apdrošinātāja vienpusēja, ārējai kontrolei nepakḷauta rīcība).

Apdrošināšanas līguma likuma 15. panta sestajā daḷā paredzētā proporcija nebūtu jān,em vērā, jo, pirmkārt, apdrošināšanas atlīdzība netiek noteikta proporcionāli no apdrošināšanas prēmijas un apdrošinātājs, iekasējot lielāku apdrošināšanas prēmiju, atlīdzību izmaksātu pilnā apmērā; otrkārt, ticami noskaidrot, cik liela prēmija tiktu noteikta, nav iespējams. Ši norma bija iekḷauta arī likumā "Par apdrošināšanas līgumu", bet nav zināmi gadỉjumi, kad tā būtu piemērota praksē.

Līguma izpildes problēma rodas arī gadījumā, ja ārējo apstākḷu maiṇa sāk būtiski ietekmēt līgumattiecības, tās neparedzēti pārveidojot. Lai gan līguma izpilde nav kḷuvusi neiespējama, jo tad varētu atsaukties uz nepārvaramu varu, tomēr tā, iespējams, kḷuvusi grūtāka un sāk neatbilst sākotnējam nodomam. Tādēḷ pamats, uz kura sākotnēji tika balstīts nodoms, var zust. Apstākḷu maiṇas ietekme uz līgumu var tikt mazināta ar netiešu nosacījumu, ka līgumslēdzējam ir tiesības izstāties no šỉ līguma, ja viṇš nekad nebūtu slēdzis šo līgumu izmainījušos apstākḷu situācijā [21, 60]. Šì doktrīna jau sen kḷuvusi pazīstama kā clausula rebus sic stantibus [13]. Apstākḷu maiṇa dažās jurisdikcijās arī vispārēji tiek atzìta par pamatu atkāpties no līguma, tomēr Latvijas tiesībās tā nav skaidri paredzèta.

Ekstrapolējot šo doktrīnu uz situāciju, kurā apdrošinātājs nesaṇem nepieciešamo informāciju pirms līguma noslēgšanas vai arī apstākḷi būtiski mainās līguma darbības laikā, būtu pareizāk noteikt, ka apdrošinātājam jābūt tiesībām atkāpties no šāda līguma, ja faktiskie tam nezināmie apstākḷi ir tādi, ka pilnīgas informācijas apstākḷos apdrošinātājs nebūtu noslēdzis apdrošināšanas līgumu [20,5-9]. Turklāt nebūtu pamatoti vērtēt, vai klients ir piel̦āvis pat vieglu neuzmanību, kas ir visai sarežgîts uzdevums.

Apdrošināšanas līguma likuma nosacījumus, kuri ir iekḷauti 15. panta septītajā daḷā un 20.-22. pantā, var uzskatīt par šîs doktrīnas realizāciju Latvijas apdrošināšanas tiesībās. Tomēr jāatzīmē, ka praksē nav zināmi šajos pantos noteiktās proporcionalitātes piemērošanas gadījumi, nav arī pamatojuma apgalvojumam, ka apdrošināšanas prēmija ir proporcionāli atkarīga no riska iestāšanās varbūtības un citiem šajās normās minētajiem apstākḷiem. Savukārt, ja apdrošinātājs noteikti atteiktos no līguma noslēgšanas, ja zinātu faktiskos apstākḷus (neatkarīgi no tā, vai klients ir vai nav pieḷāvis vieglu neuzmanību), apdrošinātājam būtu jāpieškirir tiesības atkāpties no līguma.

Runājot par klienta informācijas sniegšanu apdrošināšanas līguma darbības laikā (Apdrošināšanas līguma likuma 20. pants), vērtēšana log̣iski var tikt reducēta līdz ziṇojumam par izmaiṇām informācijā, kas tika sniegta, slēdzot līgumu. 
Jautājums ir par tādiem jauniem apstākḷiem, kas pasliktina situāciju ar risku iestāšanās varbūtību un par kuriem netika uzdots jautājums, līgumu slēdzot. Šie jaunie apstākḷi būtiski pārveido pirmslīguma situāciju. Šajā gadījumā analīze būtu veicama, ṇemot vērā jau iepriekš norādītos pirmslīguma informācijas vērtēšanas kritērijus.

Judikatūrā ir atrodamas atziṇas, ka klienta informācijas atklāšanas pienākuma saturs būtu noskaidrojams, tulkojot apdrošināšanas līguma noteikumus līguma saistību neizpildes vērtēšanā. Kaut arī atsaucei uz Civillikuma 1508. pantu būtu vajadzīgs detalizētāks skaidrojums par tā piemērošanu un to, kas strīdus attiecībās būtu atzīstams par parādnieku, kopumā var teikt, ka Augstākā tiesa lietā SKC-243/2017 pamatoti izvirza tēzi par apdrošināšanas noteikumu iztulkojumu par sliktu apdrošinātājam, cenšoties ar to pēc būtības labot likumdevēja paviršỉbu, neiekḷaujot šo nosacījumu apdrošināšanas attiecību tiesiskajā reglamentācijā [8]. Tādēl apdrošināšanas līguma noteikumu iztulkošana par sliktu apdrošinātājam ir jāiekḷauj likumā.

Jāuzsver, ka līguma noteikumu iztulkošana pretēji to jēgai nevar tikt veikta un paša informācijas sniegšanas pienākuma izpildes vērtēšanā būtu jāvadās pēc iepriekš minētā likuma regulējuma un jāizmanto šajā rakstā norādìtie kritēriji.

Atsevišḳi jāvērtē klienta pienākums sniegt patiesu informāciju par pieteikto apdrošināšanas gadījumu saskaṇā ar Apdrošināšanas līguma likuma 27. un 29. pantu (iepriekš likuma "Par apdrošināšanas līgumu" 21. un 22. pants). Latvijas tiesu praksē jau tika risināti jautājumi par klienta pienākuma neizpildi. Kaut arī likumdevējs nepatiesas informācijas sniegšanas sekas ir saistījis ar klienta vainas pakāpi (launs nolūks, rupja neuzmanība vai viegla neuzmanība), vairākos gadījumos tiesa neatzina pārkāpumu, konstatējot, ka nepatiesa informācija tika sniegta par kādu nebūtisku apstākli un neietekmēja pieteiktā gadījuma apstākḷ noskaidrošanu, nemaz nevērtējot klienta vainas pakāpi informācijas sniegšanā vai norādot, ka tieši informācijas nebūtiskums liecina par to, ka l̦auns nolūks vai rupja neuzmanība nav konstatējami.

Citkārt tiesa ir atzinusi, ka klients sniedzis apdrošinātājam nepatiesu informāciju, un tas atklāts, veicot negadijuma apstākḷu pārbaudi, kas ir likuma "Par apdrošināšanas līgumu" 21. panta pirmās dạlas pārkāpums. Šo atziṇu ir akceptējusi arī Latvijas Republikas Augstākā tiesa, izskatot lietu kasācijas kārtībā [10].

Nav gadijumu, kuros tiesa piemērotu likuma "Par apdrošināšanas līgumu" 22. panta otro daḷu, nosakot vai atzīstot par pamatotu apdrošināšanas atlīdzības samazinājumu vieglas neuzmanības gadỉjumā, vai arī tādu, kuros par to būtu strīds. Tādējādi Apdrošināšanas līguma likuma 29. panta otrās daḷas regulējums nav aktuāls.

Ja klients apdrošinātājam sniedz nepatiesu informāciju, lai nepamatoti gūtu labumu no apdrošināšanas atlīdzības, par to paredzēta kriminālatbildība. Šādas klienta darbības ir noziedzịgs nodarījums saskaṇā ar Krimināllikuma 177. un 178. pantu. [5]

Interesanti, ka par nepatiesu ziṇu sniegšanu, noslēdzot apdrošināšanas līgumu, apdrošinājuma ņēmējam paredzēta administratīvā atbildība. Latvijas Administratīvo pārkāpumu kodeksa 166.8 pantā par fiktīvu ziṇu sniegšanu, veicot mantas obligāto 
apdrošināšanu, noteikts, ka izsaka brīdinājumu vai uzliek naudas sodu līdz septiṇdesmit eiro. Tomēr šis pants praksē nevar tikt piemērots, jo Latvijas tiesībās nav paredzēta obligātā apdrošināšana, kuras objekts būtu manta. [1]

Nepilnības krimināltiesiskajā un administratīvo pārkāpumu regulējumā šeit detalizētāk netiks apskatītas specifisko iezīmju un raksta apjoma ierobežojuma dēḷ.

Veiktās analīzes rezultātā var secināt, ka klienta informācijas izpaušanas princips apdrošināšanas attiecībās prasa pareizu interpretāciju saskaṇā ar mērḳiem, kā arī tiesiskajā regulējumā par to būtu jāveic korekcijas.

\section{Nobeigums}

Klienta informācijas izpaušanas pienākums apdrošināšanas līgumos atbilst apdrošināšanas līguma dabai un palīdz noslēgt apdrošināšanas līgumu, optimizējot līguma slēgšanas izdevumus par labu klientam. Arī šã pienākuma izpildes vērtēšana, ciktāl nav konstatējams l̦auns klienta nolūks vai rupja neuzmanība, jāveic atbilstoši apdrošinātāja iespējām izvērtēt riskus un noteikt apdrošināšanas līguma noteikumus.

Nosakot tiesiskās sekas, ja klients pārkāpj informācijas izpaušanas pienākumu vieglas neuzmanības dēl, būtu jāvērtē informācijas būtiskums, lai apdrošinātājs izlemtu jautājumu par līguma noslēgšanu.

Uberrimae fidei doktrīnas pamatojums izriet no fakta, ka apdrošināšanas līgums prasa no klienta zināmu labticību un godīgumu, lai apdrošinātājam būtu iespēja pilnībā izprast apdrošināšanas objektu, ar to saistitos riskus un noteikt par to atbilstošu samaksu.

Kaut arī Latvijas Apdrošināšanas līguma likumā ir paredzēts informācijas izpaušanas pienākums, tomēr nav atklāts tā mērḳis, tādēḷ tiesu praksē ir radušās grūtības veikt mērḳim atbilstošu klienta uzvedības vērtēšanu un tiesību normu attiecināšanu uz to. Tāpat nav skaidrs un bez piemērošanas praksē palicis regulējums par sekām klienta informācijas pienākuma pārkāpšanas gadījumā vieglas neuzmanības dēll.

Atbilstīgi secinātajam var piedāvāt tiesību normu grozỉjumu priekšlikumus.

1. Izteikt Apdrošināšanas līguma likuma 8. panta pirmo dạı šãdi: "(1) Apdrošināšanas līguma noteikumiem jābūt skaidriem un saprotamiem. Priekšroka dodama tādam apdrošināšanas līguma noteikumu iztulkojumam pret citiem, kurš visvairāk saista apdrošinātāju."

2. Mainīt Apdrošināšanas līguma likuma 15. panta nosaukumu uz "Apdrošināšanas līguma noslēgšana, apdrošinātājam nesaņemot tam nepieciešamo informāciju".

3. Svītrot Apdrošināšanas līguma likuma 15. panta sesto dalıu.

4. Izteikt Apdrošināšanas līguma likuma 22. panta septīto dal̦u šādi: "(7) Apdrošinātājs izmaksā apdrošināšanas līgumā paredzēto apdrošināšanas atlīdzību, ja apdrošināšanas gadījums iestājas pirms apdrošināšanas līguma noteikumu grozišanas vai pirms tā izbeigšanas un apdrošinājuma ṇēmējs vai apdrošinātais nav izpildījis šā likuma 20. pantā noteiktās prasības, izṇemot:

1) ja tas ir noticis ar apdrošinājuma ṇēmēja vai apdrošinātā l̦aunu nolūku vai rupjas neuzmanības dēḷ; 
2) ja apdrošinātājs pierāda, ka tas nekādā gadījumā nebūtu noslēdzis apdrošināšanas līgumu, ja būtu zinājis par apdrošinātā riska iestāšanās iespējamības un iespējamā zaudējumu apmēra novērtēšanas faktiskajiem apstākḷiem, kuri atklājušies, iestājoties apdrošināšanas gadījumam; šādā gadījumā apdrošināšanas atlīdzība nedrīkst pārsniegt iemaksāto apdrošināšanas prēmiju."

5. Izteikt Apdrošināšanas līguma likuma 29. panta otro dalı šādi: "(2) Ja apdrošinājuma ñēmējs, apdrošinātais vai labuma guvējs vieglas neuzmanības dēl nav izpildījis kādu no šā likuma 27. pantā noteiktajiem pienākumiem, apdrošinātājs ir tiesīgs atteikties izmaksāt apdrošināšanas atlīdzību tikai gadījumā, ja šā pienākuma neizpildes rezultātā kḷuva neiespējams ticami nodibināt, vai pieteiktais gadījums ir vai nav atzīstams par apdrošināšanas gadījumu."

\section{Responsibility for Providing False Information to Insurance Contract}

\section{Abstract}

This article discusses the responsibility for providing false information to insurer in insurance contract in Latvian insurance law. The author of the article first gives an overview of the objectives and obligations of the parties of the insurance contract, describing the nature of the insurance contract for understanding what the reason is why insurers should receive information about an insurable object and risks prior to the insurance case. The importance of uberrimae fidei principle in insurance relations is also discussed. The article further discusses issues of determining liability and consequences of false information. The article concludes with a brief summary of solutions for improving regulation of insurance relations in Latvia related to the problems discussed.

The study has been mainly based on the analysis and synthesis method, scientific induction and deduction methods, comparative method, and observation.

Keywords: insurance contract, uberrimae fidei, contract responsibility.

\section{Avotu un literatūras saraksts}

\section{Tiesību akti}

1. Administratīvo pārkāpumu kodekss: Latvijas Republikas likums: stājies spēkā 01.07.1985. Latvijas Padomju Sociālistiskās Republikas Augstākās Padomes un Valdības Ziñotājs. 51, 20.12.1984. Iegūts no: https://likumi.lv/doc.php?id=89648 [sk. 29.03.2019.].

2. Apdrošināšanas līguma likums: Latvijas Republikas likums: stājies spēkā 01.06.2018. Latvijas Vëstnesis. 97(6183), 15.05.2018. Iegüts no: https://likumi.lv/ta/id/299053-apdrosinasanas-ligumalikums [sk. 03.03.2019.]. 
Jel̦ena Alfejeva. Atbildība par nepatiesas informācijas sniegšanu

apdrošinātājam apdrošināšanas līguma ietvaros

3. Civillikums: Latvijas Republikas likums: stājies spēkā 01.09.1992. Valdības Vēstnesis, 41, 20.02.1937. Iegūts no: https://likumi.lv/doc.php?id=225418 [sk. 08.03.2019.].

4. Eiropas Parlamenta un Padomes 2016. gada 20. janvāra Direktīva (ES) 2016/97 par apdrošināšanas izplatīšanu (pārstrādāta redakcija): starptautisks dokuments. Eiropas Savienības Oficiālais Vèstnesis. L 26/19, 02.02.2016.

5. Krimināllikums: Latvijas Republikas likums: stājies spēkā 01.04.1999. Latvijas Vēstnesis. 199/200(1260/1261), 08.07.1998. Iegūts no: https://likumi.lv/doc.php?id=88966 [sk. 30.03.2019.].

6. Par apdrošināšanas līgumu: Latvijas Republikas likums: stājies spēkā 01.09.1998., zaudējis spēku 01.06.2018. Latvijas Vēstnesis. 188/189(1249/1250), 30.06.1998. Iegūts no: https://likumi.lv/doc. php?id=48896 [sk. 03.03.2019.].

\section{Tiesu prakse}

7. Augstākās tiesas Civillietu departamenta 2015. gada 24. septembra spriedums lietā Nr. C27190010, SKC-116/2015.

8. Augstākās tiesas Civillietu departamenta 2017. gada 4. jūlija spriedums lietā Nr. C30683713 SKC-243/2017.

9. Augstākās tiesas Civillietu departamenta 2017. gada 22. decembra spriedums lietā Nr. C30711611 SKC-278/2017.

10. Augstākās tiesas Civillietu departamenta 2018. gada 28. marta spriedums lietā Nr. C30419915 SKC-75/2018.

11. Augstākās tiesas Senāta Civillietu departamenta 2013. gada 12. jūnija spriedums lietā Nr. SKC-43/2013.

12. G̦enerāladvokātes Eleanoras Šarpstones (Eleanor Sharpsgton) secinājumi, sniegti 2014. gada 12. jūnijā lietā C-51/13 Nationale-Nederlanden Levensverzekering Mij NV pret Hubertus Wilhelmus van Leeuwen. Iegūts no: http://curia.europa.eu/juris/document/document_print.jsf; jsessionid=9ea7d2dc30d5b8a88f0af8724495958ac8a27ef5c6e1.e34KaxiLc3qMb40Rch0SaxyLa hf0?doclang=LV\&text=\&pageIndex=0\&docid=153606\&cid=166347 [sk. 30.03.2019.] .

\section{Literatūra}

13. Abas, P. 1989. Rebus sic stantibus. Deventer: Kluwer.

14. Beatson, J., Friedmann, D. 1995. Good faith and fault in contact law. Clarendon Press.

15. Burling, J., Lazarus, K. 2012. Research Handbook on International Insurance Law and Regulation. Edward Elgar Publishing. Iegūts no: https://EconPapers.repec.org/RePEc:elg:eebook:14215 [sk. 22.01.2019.].

16. Dixit, A. 2000. Adverse Selection and Insurance with Uberrima Fides, in Incentives, Organization, and Public Economics: Essays in Honor of Sir James Mirrlees. Eds. Peter J. Hammond and Gareth D. Myles. Oxford: Oxford University Press.

17. Dixit, A., Picard, P. 2003. On the Role of Good Faith in Insurance Contracting. In: Economics for an imperfect world: Essays in honor of Joseph E. Stiglitz. Cambridge and London: MIT Press.

18. Eiropas vērtēšanas standarti: astotā redakcija. Eiropas Vērtētāju asociāciju grupa TEGoVA. 2016. Iegūts no: https://www.vertetaji.lv/upload/rev/evs_2016_lv_darba.doc [sk. 01.04.2019.].

19. Heiss, H., Lakhan, M. 2011. Principles of European Insurance Contract Law: A Model Optional Instrument With a Postscript in Honour of Fritz Reichert-Facilides. Project Group Restatement of European Insurance Contract Law Extent. Universität Insbruck. Iegūts no: www.restatement. info [sk.12.01.2019.]. 
Jeḷena Alfejeva. Atbildỉba par nepatiesas informācijas sniegšanu apdrošinātājam apdrošināšanas līguma ietvaros

20. Hondius, E., Grigoleit, C. 2011. Unexpected Circumstances in European Contract Law. The Common Core of European Private Law. Cambridge University Press.

21. Hutchison, A. 2009. Change of Circumstance in Contract Law: The Clausula Rebus sic Stantibus. Journal of Contemporary Roman Dutch Law. 72, 60-73.

22. Johnson, A. M. 2008. An economic analysis of the duty to disclose information: Lessons learned from the caveat emptor doctrine. San Diego Law Review. 45, 79-132.

23. Kārkliṇš, J. 2006. Latvijas līgumtiesību modernizācijas galvenie virzieni. Promocijas darba kopsavilkums juridisko zinātṇu doktora zinātniskā grāda iegūšanai. Rīga: Latvijas Universitāte. Iegūts no: https://dspace.lu.lv/dspace/bitstream/handle/7/290/Karklins_J_Latvijas_ligumtiesibu_modernizacijas_2006_Kopsav_LV.pdf?sequence=2 [sk. 22.01.2019.].

24. Lowry, J., Rawlings, P., Merkin, R. 2011. Insurance Law: Doctrines and Principles. 3rd ed. Hart Publishing.

25. Mantrovs, V. 2018. Apdrošināšanas atlīdzības izmaksas atteikuma regulējums Latvijā. Latvijas Universitātes 76. starptautiskās zinātniskās konferences rakstu krājums. Latvijas Universitāte. Iegūts no: https://www.lu.lv/fileadmin/user_upload/lu_portal/apgads/izdevumi/2018/Book_76_ juristu_konference_2018_-gala.pdf [sk. 22.01.2019.].

26. Rothschild, M., Stiglitz, J. 1976. Equilibrium in Competitive Insurance Markets: An Essay on the Economics of Imperfect Information. Quarterly Journal of Economics. 90, 629-649.

27. Strauss, J. D. 2008. Uberrimae Fidei and Adverse Selection: the Equitable Legal Judgment of Insurance Contracts. MPRA. Iegūts no: http://mpra.ub.uni-muenchen.de/10874/1/_Strauss_ Utmost_Good_Faith_and_Adverse_Selection_Equitable_Legal_Judgment_of_Insurance_ Contracts.pdf [sk. 29.01.2019.].

28. Strazdiṇš, G̦. 2018. Vispārējais zaudējumu atlīdzības prasījuma pamats delikta un saistības pārkāpuma gadījumā. Jurista Vārds. 06.02.2018., 6(1012), 12.-15.

29. Watterson, S. 2008. Carter v Boehm (1766). In: Landmark cases in the law of contract. Mitchell Charles and Mitchell Paul eds. Hart Publishing. 
https://doi.org/10.25143/socr.13.2019.1.076-095

\title{
Prasijuma tiesību noilgums zemes likumiskajā (piespiedu) nomā
}

\author{
Arta Snipe \\ Latvijas Universitāte, Juridiskā fakultāte, \\ Doktora studiju programma \\ arta@snipe.lv
}

\section{Kopsavilkums}

Pēc Latvijas valsts neatkarības atjaunošanas uzsāktajā zemes reformā, atjaunojot bijušajiem īpašniekiem vai vinu mantiniekiem ipašuma tiesības uz zemi, uz kuras padomju varas gados bija uzceltas daudzdzīvokḷu dzīvojamās ēkas, likumdevējs radīja pamatu tā saukto dalïto īpašumu pastāvēšanai, pieņemot lēmumu zemes un ēkas īpašnieku starpā esošās attiecības regulēt atbilstoši nomas līguma noteikumiem. Šo tiesisko attiecību nodibināšanas pamats ir likums - normas, kas iekḷautas likumā "Par zemes reformu Latvijas Republikas pilsētās" un likumā "Par valsts un pašvaldību dzīvojamo māju privatizāciju".

Šā pētijjuma mērḳis ir izvērtēt dažādo tiesu praksi un dažādos juridiskajā periodikā paustos viedokḷus, interpretējot spēkā esošās tiesību normas un judikatūras atziṇas, lai identificētu prasījuma tiesību rašanās brīdi, kas ir prasījuma tiesību noilguma tecējuma sākuma brīža noteikšanas priekšnoteikums.

Pētījumā ir secināts, ka jānoškir prasījuma tiesības par zemes nomas tiesisko attiecību konstatāciju vai līguma noslēgšanu un prasijuma tiesības par nomas līguma izpildi nomas maksas samaksu. Pēdējās rodas vien pēc līguma noslēgšanas vai tiesas sprieduma spēkā stāšanās. Šajā brīdī arī sāk tecēt noilgums prasījuma tiesībām, kas izriet no noslēgtā nomas līguma. Tiesību normu interpretācijas un tiesību doktrīnas un judikatūras analīzes rezultātā pētỉjumā secināts, ka prasījuma tiesības par zemes nomas tiesisko attiecību konstatāciju vai nomas līguma noslēgšanu pret personu, kas veic daudzdzīvokḷu ēkas pārvaldīšanu un apsaimniekošanu, zemes īpašniekam rodas no brī̌̌a, kad apsaimniekotājs ir pārṇēmis konkrētās ēkas pārvaldīšanu, vai no zemes īpašuma tiesību iegūšanas brīža atkarībā no tā, kas iestājies pēdējais, savukārt prasỉjuma tiesības par zemes nomas tiesisko attiecību konstatāciju un nomas maksas piedziṇu pret atsevišķiem dzìvokḷu īpašniekiem zemes īpašniekam ir radušās vien pēc 2015. gada 1. oktobra, kopš likums piel̦auj tiešo maksājumu pieprasišanu par ēkas uzturēšanai nepieciešamajiem pakalpojumiem. 
Atslēgvārdi: zemes piespiedu noma, tiesisks darïjums, komercdarïjums, prasïjuma tiesības, noilgums, komerctiesiskais noilgums.

\section{levads}

Pēc Latvijas valsts neatkarības atjaunošanas uzsāktajā zemes reformā [8] bijušajiem īpašniekiem vai viṇu mantiniekiem tika atjaunotas īpašuma tiesỉbas uz zemes ỉpašumiem, kas no 1940. līdz 1980. gadam bija atṇemti, zemi kā nekustamo īpašumu izṇemot no civiltiesiskās aprites. Vienlaikus tika saglabātas vai piešḳirtas īpašuma tiesības uz virszemes nekustamo īpašumu - ēkām un būvēm, kas likumīgi bija uzbūvētas līdz Latvijas okupācijai vai padomju gados, - šo būvju ĩpašniekiem vai tiesiskajiem valdītājiem. Tā zemes īpašnieku un būvju īpašnieku starpā izveidojās piespiedu tiesiskās attiecības, ko likumdevējs izvēelējās regulēt atbilstoši nomas līgumu regulējošajām tiesību normām [10]. Šādas attiecības tiek dēvētas par zemes likumisko vai piespiedu nomu [49].

Tiesību zinātnē un judikatūrā ir nostiprinājusies atziṇa, ka šìs nomas attiecības pastāv neatkarīgi no pušu gribas, tām ir piespiedu raksturs [39], šìm attiecībām ir tikai nosacīta līdzỉba ar līgumiskām attiecībām [22; 64, 347], jo būtībā šìs attiecības ir likumiskas [20; 37]. Par līgumu dēvētais fakts īstenībā nav līgums [65, 109], savukārt atlīdzība nomas maksas veidā pēc juridiskās dabas pielīdzināma maksājumam par zemes īpašuma tiesību aprobežojumu [20]. Pastāvot piespiedu nomas tiesiskajām attiecībām, nav pamata runāt par lietas nodošanu lietošanā un tās pieņemšanu no otras puses, kas saskaņā ar Civillikuma vispārējās daḷas normām nodibina nomas līgumu.

Lìdz pat 2016. gadam tiesību zinātnē un tiesu praksē maz tika pētìts saistìbas un prasijuma tiesību, kas radušās uz zemes piespiedu nomas pamata, rašanās pamats un nodibināšanas brīdis, kā arī tas, vai zemes nomas maksas prasījumi ir pakḷauti vispārējam civiltiesiskajam noilgumam vai speciālajam (saīsinātajam) komerctiesiskajam noilgumam. 2017. gada sākumā, kad plašsaziṇas līdzekḷos tika aktualizēts jautājums par 10 gadu vecu zemes nomas maksas parādu piedziṇu [66; 67], savus skaidrojumus tiesību normu piemērošanā sniedza Patērētāju tiesību aizsardzības centrs [68] un Tieslietu ministrija [71]. Uz šīm publikācijām konkrētos strīdos sāka atsaukties tiesas [47; 53], kā arī atsevišḳi raksti tika publicēti juridiskajā periodikā un krājumos [57; 61].

Šã pētỉjuma pirmajā dal̦ā secināts, ka zemes piespiedu noma nav atzīstama par tiesisku darījumu Civillikuma izpratnē, un tātad tā nav atzīstama par komercdarījumu Komerclikuma izpratnē, savukārt pētījuma nākamās daḷas mērḳis ir identificēt un atrisināt prasījuma tiesību, kas saistītas ar zemes piespiedu nomu, noilguma jautājumus, šim nolūkam identificējot prasījuma tiesības, kuras ir piespiedu nomas tiesisko attiecību dalībniekiem, šo prasījuma tiesību rašanās brīdi, katra prasījuma noilguma tecējuma sākuma brīdi un noilguma pārtraukšanas iespējas. Rakstā ietverta padziḷināta tiesību normu, judikatūras, tiesu prakses un tiesību periodikā izteikto viedokḷu analīze, vērtējot pušu argumentu pamatotību, lai, pirmkārt, identificētu prasījuma tiesību pamatu, otrkārt, 
prasījuma tiesību rašanās brīdi un noilguma tecējuma sākuma brīdi, un, treškārt, secinātu, vai zemes ỉpašnieka prasījuma tiesībām, kas izriet no piespiedu nomas tiesiskajām attiecībām, ir pamats piemērot saīsinātā (komerctiesiskā) noilguma termiṇu.

\section{Prasijjuma tiesību rašanās brīdis piespiedu nomā}

Tiesību normās ir ierakstīts un Satversmes tiesas spriedumos nostiprināts, ka piespiedu noma ir atzīstama par nomas līgumu, proti, institūtu, kura vispārējais regulējums meklējams Civillikuma Saistību tiesību dạ̦ā. Pirms izvērtēt noilguma jautājumus prasījumiem, kas izriet no zemes piespiedu nomas tiesiskajām attiecībām, jāidentificē prasījuma tiesību rašanās brīdis. Lai konstatētu prasījuma tiesību rašanās brīdi, jāidentificē un jānošḳir prasijjuma tiesības, kuru rašanās pamats ir īpašuma tiesības, no prasījuma tiesībām, kas izriet no saistību tiesībām, kuru rašanās pamats ir darījums vai kuras izriet no saistības, kas radusies pēc likuma.

Civillikuma 1402. pantā [1] paredzēti vairāki saistības rašanās pamati, un piespiedu nomas tiesiskajās attiecībās saistības var pastāvēt gan uz likuma pamata, gan arī uz pušu starpā rakstveidā noslēgta nomas līguma pamata. Ja puses ir noslēgušas rakstveida nomas līgumu, tās var vienoties par līguma noteikumiem: papildu platības nomu, nomas maksas apmēru un tās samaksas termiṇiem. Ja līgums nav noslēgts, prasījuma tiesību un atbilstošo pienākumu saturs ir tāds, kāds noteikts likumā. Tāpēc katrā konkrētā situācijā būtiski ir noskaidrot faktiskos apstākḷus. Vai nomas attiecības un no tām izrietošais prasījums izriet no tiesiska darījuma (komercdarījuma, ja kāda no darījuma pusēm ir komersants) vai arī prasījums izriet no likuma? Tāpat atšḳirīgs ir prasījuma tiesību saturs un rašanās brīdis pret dažādiem subjektiem: daudzdzīvokḷu dzīvojamās ēkas gadījumā tas var būt gan pārvaldnieks vai cita pilnvarota persona, gan arī pats dzīvokḷa īpašnieks.

\section{Nomas līgums ir noslēgts rakstveidā}

Ja puses ir noslēgušas rakstveida līgumu (cita līguma forma kop̌̌ 2009. gada 1. novembra netiek piel̦auta attiecībā uz nomas maksas apmēru privatizējamās vai privatizētās un kooperatīvajās mājās saskaṇā ar likuma "Par zemes reformu Latvijas Republikas pilsētās" [10] 12. panta otro prim dạı un likuma "Par valsts un pašvaldību dzīvojamo māju privatizāciju" [9] 54. panta otro daḷu), prezumējams, ka tās tostarp ir vienojušās ne vien par nomas maksas apmēru, bet arī par tās samaksas terminiem. Prasījuma tiesības par darījuma izpildi un pielīgtās nomas maksas samaksu radīsies brīdì, kad debitors līgumu neizpildīs tajā noteiktajos termiṇos.

Zemes īpašnieks prasījuma tiesības var realizēt vien iestājoties pielīgtajam nomas maksas samaksas termiņam - pirms tam prasījums ir atzīstams par priekšlaicīgu [12; 13; 22; 31]. Prasības celšana iespējama vienīgi tad, kad notikusi indivīda tiesību 
pārkāpšana [12]. Pirms tam arī neiesākas prasījuma tiesību par līguma izpildi noilguma tecējums [1, 1896. pants]. Gadījumos, ja kāda no darījuma pusēm (ne tikai kreditors) ir komersants un rakstveidā noslēgtais darījums ir atzīstams par komercdarījumu (tas atbilst komercdarïjuma pazīmēm), prasỉjumiem, kas izriet no rakstveidā noslēgtā zemes nomas līguma, ir pamats piemērot Komerclikuma normas, kurās noteikti terminini un nosacījumi, kuros ir îstenojamas no komercdarījuma izrietošās prasījuma tiesības [61].

\section{Rakstveida nomas līgums nav noslēgts}

Ja pušu starpā rakstveida līgums nav noslēgts, tiesiskās attiecības, kā arī zemes ipašnieka prasijuma tiesības izriet no likuma: "Par zemes reformu Latvijas Republikas pilsētās" 12. panta, "Par valsts un pašvaldību dzīvojamo māju privatizāciju" 54. panta, kā arī 50. panta pirmās dal̦as un Dzìvojamo māju pārvaldīšanas likuma [2] 6. panta otrās daḷas 4. punkta un 17. ${ }^{7}$ panta. Būtiski ir nošḳirt zemes īpašnieka prasījuma tiesības par zemes nomas tiesisko attiecību konstatāciju vai nomas līguma noslēgšanu [18] no prasījuma tiesību, kas izriet no jau tiesas ceḷā vai privātautonomijas izpausmes veidā noslēgta nomas līguma, izpildes.

Likuma "Par zemes reformu Latvijas Republikas pilsētās" 12. panta trešajā daḷā, kas piemērojama pušu tiesiskajām attiecībām līdz daudzdzīvokḷu dzīvojamās ēkas nodošanai privatizācijai, noteikts, ka zemes īpašniekam ir tiesības saṇemt nomas maksu no ēku un būvju īpašnieka. Panta otrajā prim dal̦ā tiek regulēts nomas maksas apmērs. Tiesību normā nav ietverta norāde par nomas priekšmetu - tas ir jākonstatē tiesai, ja nav nodibināts ar likumu atbilstoši likuma 13. panta trešajā daḷā noteiktajam. Pusēm uz likuma pamata pastāvošajās piespiedu nomas attiecībās ir savstarpējas prasījuma tiesības uz nomas līguma noslēgšanu. Šo prasījumu mērḳis zemes ỉpašniekam, no vienas puses, ir aizsargāt viṇa likumā garantētās tiesības saṇemt no ēkas īpašnieka samaksu par zemes lietošanu, bet, no otras puses, ēkas īpašniekam - nodrošināt viṇa tiesības netraucēti valdìt un lietot viṇam piederošo ēku [21].

Likuma "Par zemes reformu Latvijas Republikas pilsētās" 12. pants ir tulkojams kā "zemes un ēkas ìpašniekam dots uzdevums savstarpēji saistīties, noslēdzot lïgumu atbilstoši brīvprātības principam, savukārt, ja vienošanās par līguma noteikumiem nenotiek - strīda gadījumā, nomas tiesisko attiecību konstatāciju (atzī̌̌anu) veic tiesa, nodibinot ar tiesas spriedumu nomas līguma būtiskās sastāvdaḷas," [28] kā tas paredzēts Civillikuma 2124. pantā. Lai gan zemes ippašniekam ir tiesības saṇemt zemes nomas maksu, tomēr šā prasījuma priekšnoteikums ir nomas tiesisko attiecību konstatācija (nodibināšana). Tikai pēc sprieduma spēkā stāšanās darījums ir atzīstams par noslēgtu, jo tikai tad ir nodibinātas darījuma būtiskās sastāvdaḷas (Civillikuma 1533. pants) [24], tiesas spriedumam aizstājot cita akta taisǐšanu [17; 28; 37]. Secīgi par darïjuma noslēgšanas brīdi atzīstams tiesas sprieduma spēkā stāšanās brīdis. Lìdzīgu skaidrojumu saistībā ar Pievienotās vērtības nodokḷa likuma 127. panta pirmās daḷas un 131. panta pirmās daḷas piemērošanu ir sniedzis Valsts ien̦ēmumu dienests, norādot, ka par zemes nomas 
pakalpojuma sniegšanas brīdi strīdus gadījumā uzskata brīdi, kad stājies spēkā spriedums par zemes nomas tiesisko attiecību konstatāciju un parāda piedziṇu, no šīs dienas skaitot piecpadsmit dienu termiṇu nodokḷa rēḳina izrakstišanai [70].

\section{Prasījuma tiesības pret ēkas pārvaldnieku}

Procesuālās ekonomijas nodrošināšanai speciālajās tiesību normās paredzētas zemes īpašnieka prasījuma tiesības pret daudzdzīvokḷu èkas pārvaldnieku prasījumā par zemes nomas līguma noslēgšanu. Tomēr šīs prasījuma tiesības ierobežo pārvaldnieka pilnvarojuma apjoms - tikai likumā noteiktā kārtībā pilnvarots pārvaldnieks var būt atbildētājs prasībā par zemes nomas līguma noslēgšanu un tā izpildi.

Ar daudzdzīvokḷu dzīvojamās ēkas privatizācijas uzsākšanu tiesiskās attiecības ēkas un zemes īpašnieku starpā sāk regulēt likuma "Par valsts un pašvaldỉbu dzīvojamo māju privatizāciju" 54. pants, kā arī 50. panta pirmās daḷas 3. punkts [62]. Šā likuma normas reglamentē dzīvokḷu īpašnieku, pārvaldnieka un zemes īpašnieka savstarpējās attiecības līdz brīdim, kad dzīvojamās mājas īpašnieki pārṇem dzīvojamās mājas pārvaldīšanas tiesības no publiskās personas, kura ēku ir privatizējusi [29].

Likuma "Par valsts un pašvaldību dzīvojamo māju privatizāciju" 54. pantā, kā arī 50. panta pirmās dal̦as 3. punktā noteikts privatizētā objekta īpašnieka "pienākums slēgt zemes nomas līgumu" vai pilnvarot dzìvojamās mājas pārvaldìtāju slēgt zemes nomas līgumu ar tā zemesgabala īpašnieku, uz kura atrodas privatizētais objekts. No otras puses, zemes ìpašnieka pienākums noslēgt nomas līgumu ar privatizētā objekta ìpašnieku noteikts likuma 54. panta pirmajā daḷā. Zemes īpašnieka prasijuma tiesības nostiprinātas likuma 54. panta ceturtajā daḷā, kurā precizēts - ja atbilstoši šã likuma 50. panta pirmās daḷas 3. punkta prasībām zemes nomas līgumi ar zemesgabala ỉpašnieku nav noslēgti, zemesgabala īpašniekam ir tiesības prasību tiesā par zemes nomas līguma noslēgšanu vērst pret personu, kurai nodotas attiecīgās dzīvojamās mājas pārvaldīšanas un apsaimniekošanas tiesības.

Šì norma expressis verbis neparedz pret pārvaldnieku vērst prasījumu par zemes nomas maksas samaksu. Tomēr "Civilprocesa likums neparedz personai iespēju tiesas ceḷā prasīt konstatēt zināmas tiesiskās attiecības esamību vai neesamību, prasībai jābūt vērstai uz konkrēta tiesību aizskāruma novēršanu" [12; 13; 23; 29; 31], bet prasījums, kas neietver mantisku prasījumu - konkrēta tiesību aizskāruma novēršanu - ir atzīstams par bezpriekšmetisku. No minētā var secināt, ka zemes īpašnieks nevar celt prasību, lai konstatētu tiesiskās attiecības esamību, neiekḷaujot mantisku prasijjumu par nomas maksas piedzinu, viņš nevar arī celt prasību par nomas tiesisko attiecību nodibināšanu nākotnē [44]. Prasījums par nomas tiesisko attiecību konstatēšanu, kas var būt vērsts tikai uz pagātni, tiek atzīts par pakārtotu prasījumu, kas nepieciešams nomas parāda noteikšanai [43]. Tiesa nomas tiesiskās attiecības var konstatēt, nosakot to būtiskās sastāvdaḷas, vien pagātnē un nosacītā tagadnē - līdz brīdim, kad tiek pabeigta lietas izskatīšana pēc būtïbas. Prasība par piespiedu nomas tiesisko attiecibu nodibināšanu uz termiṇu, kurš vēl 
nav iestājies, nav iespējama, jo šāds prasījums ietvertu tikai hipotētiskus apgalvojumus, kas nav pierādāmi, piemēram, nākotnes atbildētājs, prasījuma priekšmets (funkcionāli nepieciešamais zemesgabals var tikt grozìts administratīvajā procesā noteiktajā kārtībā), nomas maksas apmērs (nomas maksas apmērs nosakāms atbilstoši normatīvajam regulējamam, kas spēkā attiecīgajā laika periodā).

Ja zemes ipašnieks labprātīgi vai tiesas ceḷā ir vienojies ar atbilstoši pilnvarotu dzīvojamās mājas pārvaldnieku vai dzīvokḷu īpašnieku pilnvarnieku par nomas līguma būtiskajām sastāvdaḷām, tiesības un pienākumi, kas izriet no šì līguma, vienlīdz attiecas un ir saistoši dzīvojamās mājas dzīvokḷu īpašniekiem, jo tieši viṇi ir zemes nomas tiesisko attiecību subjekti $[19 ; 69]$.

Likuma "Par valsts un pašvaldību dzīvojamo māju privatizāciju" 54. panta ceturtajā daḷā paredzētas prasītāja tiesības ēkas privatizācijas procesa gaitā celt vienu prasību pret ēkas pārvaldnieku, kuram attiecīgi ir regresa prasības tiesības pret ēkas dzivoklı ìpašniekiem [16]. Pret èkas pārvaldnieku zemes īpašniekam ir prasijuma tiesības par zemes nomas tiesisko attiecību konstatāciju un nomas līguma izteikšanu akta formā - būtisko sastāvdal̦u nostiprināšanu spriedumā (kā tas expressis verbis redzams no likuma 54. panta ceturtās daḷas), šo prasījumu saistot ar mantisko (parāda piedziṇas) prasījumu no brīža, kad pārvaldnieks ir pārnẹemis konkrētās ēkas pārvaldī̌anu un apsaimniekošanu, vai no zemes īpašuma tiesību iegūšanas brīža, atkarībā no tā, kas iestājies pēdējais [29]. Valsts vai pašvaldības nozīmētais un pilnvarotais pārvaldnieks ir atbildīgs par zemes nomas līguma noslēgšanu ēkās, kuras nav pārṇēmuši dzīvokḷu ỉpašnieki [26], un šis saistības, ja tās nav izpildìtas, mainoties ēkas pārvaldniekiem, kḷust saistošas nākamajam pārvaldniekam [34]. Pārvaldnieka atbildība nav aprobežota ar saistībām, ko dzīvokḷu īpašnieku kopība (kopsapulce) ir uzṇēmusies pēc jaunā pārvaldnieka izvēles. Mainoties ēkas pārvaldniekam, jaunajam pārvaldniekam ir pienākums iestāties lietā kā iepriekšejā pārvaldnieka tiesību un saistību pārṇēmējam. Par mājas apsaimniekošanu un zemes nomas līguma noslēgšanu, tostarp arī parādu nomaksu, kas izriet no mājas apsaimniekošanas vajadzībām noslēgtajiem līgumiem, atbildīgs ir dzīvojamās ēkas ikreizējais pārvaldnieks, kuram ir prasības tiesības pret dzīvokḷu ìpašniekiem [25].

Ēkā, kurā privatizācija pabeigta, ja pārvaldnieks ir noslēdzis pilnvarojuma līgumu, uzṇemoties veikt obligātās pārvaldīšanas darbības, tam ir pienākums paredzēt arī izdevumus par dzīvojamai mājai piesaistītā zemesgabala nomu, un tas nozīmē gan pienākumu informēt dzīvokḷu īpašnieku kopību, gan veikt nepieciešamo līdzekḷu iekasēšanu no mājas īpašnieka [27]. Dzīvojamo māju pārvaldīšanas likuma $17{ }^{2}$ pantā noteiktajā kārtībā noslēgta pilnvarojuma līguma esamības gadījumā zemes īpašniekam ir prasījuma tiesības pret ēkas pārvaldnieku. Šādās prasībās atbildētājs (pārvaldnieks) it kā darbojas kā ēkas dzīvokḷu īpašnieku pārstāvis, lai gan ir patstāvīgs lietas dalībnieks. Šĩ juridiskā konstrukcija nav bieži sastopama, bet tās mērḳis ir procesuālā ekonomija: ja vienā strīdus pusē ir liels daudzums iespējamo prāvnieku, tiek noteiktas šādas pārstāvības tiesības, piemēram, tās ir arī kolektīvā pārvaldījuma organizācijai Autortiesību likumā. 
Dzīvojamo māju pārvaldīšanas likuma normās, to skaitā likuma 6. panta otrās daļas 4. punktā, noteikts, ka zemes nomas līguma slēgšana ir obligāta pārvaldīšanas darbība. Judikatūrā šì norma tulkota tā, ka bez nomas līguma noslēgšanas ēkas pārvaldīšana nav iespējama $[16 ; 33]$, un tas nozīmē, ka "dzīvojamās mājas apsaimniekošanas un pārvaldīšanas līguma esamība izslēdz vajadzību pēc kāda speciāla pilnvarojuma no dzīvokḷu īpašnieku puses par zemes nomas līguma slēgšanu”. Dzìvokḷ i ipašnieku vienpusējs paziņojums par pilnvarojuma neesamību pārvaldniekam nomas līguma slēgšanai nevar ierobežot likumā noteikto pārvaldnieka pilnvaru apjomu, tostarp būt par atbildētāju prasībā $[18 ; 32 ; 35 ; 36]$. Šis princips - liegums sašaurināt likumā noteikto pilnvarojuma apjomu - nostiprināts, piemēram, attiecībā uz prokūru Komerclikuma [6] 36. panta pirmajā daḷā.

Tomēr būtiski ir nošķirt, ka pret pārvaldnieku prasība nav vēršama gadỉjumā, ja tas pārvaldīšanas tiesības nodevis un konkrēto dzīvojamo ēku vairs neapsaimnieko. Izbeidzoties pārvaldīšanas tiesībām, tikai mājas (dzīvokḷu) īpašnieki vai nākamais pārvaldnieks, ja to paredz pārvaldīšanas līgums, var risināt jautājumus, kas saistīti ar piespiedu nomas tiesiskajām attiecībām [41, 7.2. punkts].

\section{Prasijuma tiesības pret atsevišḳiem dzivokḷu îpašniekiem}

Jānošḳir ir brīdis, kad zemes īpašniekam rodas prasījuma tiesības pret ēkas pārvaldnieku, un brīdis, kad rodas prasījuma tiesības pret atsevišķu dzīvokḷu ìpašniekiem.

Vēsturiski ir nodalāmi trīs posmi ar dažādu tiesisko regulējumu:

- lïdz 2014. gada 1. oktobrim, kad Civillikuma 1068. pants liedza îstenot prasijuma tiesības pret atsevišķu dzīvokḷu īpašniekiem (ēkas kopīpašniekiem);

- no 2014. gada 1. oktobra lïdz 2015. gada 1. oktobrim, kad saistibas saturs bija noteikts ar likumu, bet tiesību normas neparedzēja atsevišķu prasījumu vēršanu pret dzīvokḷa īpašniekiem;

- no 2015. gada 1. oktobra, kad likums sāka regulēt tiešos norēḳinus pakalpojuma sniedzēja un dzīvokḷa ìpašnieka starpā.

2014. gada 1. oktobrī spēkā stājās grozìjumi likuma "Par valsts un pašvaldību dzīvojamo māju privatizāciju" 54. panta pirmajā daḷā, kas kopsakarā ar Satversmes tiesas spriedumā lietā Nr. 2011-01-01 [52] lemto radijja juridisku pamatu prasību celšanai pret atsevišḳiem dzīvokḷu ipašniekiem par zemes nomas maksas piedzinnu. Lìdz 2014. gada 1. oktobrim - atbilstoši Satversmes tiesas lemtajam un judikatūrai - prasijums par zemes nomas līguma noslēgšanu bija jāizvirza visiem zemes kopipašniekiem, ja tie ir, pret visiem dzīvokḷu īpašniekiem kā ēkas kopīpašniekiem, jo atbilstoši Civillikuma 1068. pantam tiesai nebija tiesību noteikt nomājamo platību zemes îpašnieka individuālā strīdā ar vienu dzīvokḷu īpašnieku. Tiesas pieturējās pie ieskata, ka domājamā daḷa ir bezḳermeniska lieta, ko nevar iznomāt [59; 64], to tulkojot tādējādi, ka Civillikuma 1068. pantā liegts celt prasību par zemes nomas līguma noslēgšanu kopipašniekam vai pret kopīpašnieku [38]. 
Ar pieminētajiem grozījumiem [5] likumdevējs expressis verbis likumā noteica abas nomas līguma būtiskās sastāvdaḷas: ja cena likumā bija noteikta jau kopš 2009. gada 1. novembra, tad ar 2014. gada 1. oktobri likumā imperatīvi tika noteikta arī nomājamā platība. Formāli, sākot ar 2014. gada 1. oktobri, zemes īpašniekam vairs nebija nepieciešama zemes nomas tiesisko attiecību konstatācijas prasība - līguma būtiskās sastāvdaḷas attiecībā uz privatizācijai nodotām dzīvojamām ēkām bija noteiktas likumā [54].

Vienlaikus, lai arī likumā bija nostiprinātas darījuma būtiskās sastāvdaļas, Dzīvojamo māju pārvaldǐšanas likumā līdz pat 2015. gada 30. septembrim nebija paredzēts, ka dzīvokḷu ìpašnieki varētu slēgt līgumus vai norēḳināties ar zemes īpašnieku patstāvīgi. Tikai 2014. gada 15. janvārī spēkā stājās grozījumi [4], kas Dzīvojamo māju pārvaldīšanas likumā ieviesa tā sauktos "tiešos norēḳinus" - dzīvokḷu ỉpašnieku tiesības izvēlēties, vai maksājumus par saṇemtajiem pakalpojumiem, to skaitā zemes nomu, veikt ar pārvaldnieka starpniecību vai kā tiešos maksājumus. Likuma pārejas noteikumos (15.-22. punktā) bija noteikts, ka tiešie maksājumi par pakalpojumiem uzsākami ne agrāk kā 2015. gada 30. septembrī. Lìdz šim datumam zemes īpašniekam, kā jebkuram pakalpojumu sniedzējam, likums nedeva tiesības izrakstìt rēkinus tieši dzīvokḷu īpašniekiem un formāli pat ne tiesības noskaidrot dzīvokḷu īpašnieku personas datus, lai informētu vinuus par nesamaksāto zemes nomas maksu. No likuma pārejas noteikumu 23. punkta izriet, ka līdz šim datumam zemes ìpašniekam nebija prasījuma tiesību pret katru atsevišķu dzīvokḷa īpašnieku, jo likumdevējs bija paredzējis zemes nomas - tāpat kā citu ar ēkas uzturēšanu saistīto pakalpojumu - līgumu slēgšanu nodrošināt ar mājas pārvaldnieka starpniecību, un zemes ìpašniekam līdz minētajam datumam prasījuma tiesības bija vien pret ēkas pārvaldnieku. Dzīvojamo māju pārvaldīšanas likuma pārejas noteikumu 23. punkts kopsakarā ar Civillikuma 1071. pantā nostiprināto kopīpašnieku pienākumu segt uz kopējo lietu gulošās nastas, apgrūtinājumus un lietas uzturēšanai vajadzīgos izdevumus samērīgi ar viṇu dạ̦ām un Dzīvokḷa īpašuma likuma [3] 13. panta pirmajā daḷā nostiprinātais dzīvokḷa īpašnieka pienākums segt izdevumus obligāti veicamo dzīvojamās mājas pārvaldīšanas darbību veikšanai, pie kurām pieskaitāma arī ēkas uzturēšanai nepieciešamā zemesgabala noma, - tas viss ir radījis tiesisku pamatu zemes ipašnieka prasījuma tiesību nodibināšanai pret atsevišḳiem èku dzīvokḷu īpašniekiem prasībā par zemes nomas tiesisko attiecību konstatāciju un nomas maksas piedziṇu vai prasījuma tiesības pret zemes nomas maksas piedziņu.

Attiecībā uz prasījumiem pret atsevišķu dzìvokḷ ìpašniekiem, kas radušies pēc 2015. gada 1. oktobra, var pastāvēt atšḳirīgi viedokḷi par piespiedu nomas kā darījuma noslēgšanas brīdi - darījuma būtiskās sastāvdal̦as ir noteiktas likumā, tādēl darījumu varētu atzìt par noslēgtu ar pašu zemesgabala lietošanas faktu. Tomēr šāda pieeja ir iespējama, pirmkārt, vien attiecībā uz ēkām, kurām uzsākta un nav pabeigta privatizācija, un par laikposmu, par kuru likumā nomas maksa ir viennozīmīgi noteikta, t. i., ka nevienošanās gadījumā tie ir $6 \%$ no zemesgabala kadastrālās vērtības gadā. Tomēr arī attiecībā uz šiem objektiem nevar izslēgt strīda esamību par funkcionāli nepieciešamā zemesgabala platîbu (piemēram, vai tā pareizi aprēķināta; īpaši, ja ēka atrodas uz 
vairākiem zemesgabaliem; vai pareizi aprēḳināta kadastrālā vērtība par zemes vienību, ja tā ir reǵistrēta) vai, kopš 2019. gada 1. maija, - par nomas maksas apmēru. Arī Augstākās tiesas Civillietu departaments ir apstiprinājis judikatūras tēzi, ka piespiedu nomas strīdos tiesai jāizškirir strīds par līguma būtiskām sastāvdaḷām (Civillikuma 1533. pants), nevis par nomas tiesisko attiecību atzīšanu. Ja puses nevar panākt vienošanos par blakus noteikumiem, kas nav atzīstami par būtiskām darījuma sastāvdaḷām, tad bez vienošanās par blakus noteikumiem līgums nav atzīstams par noslēgtu, kā tas noteikts Civillikuma 1534. pantā [36]. No minētā izriet, ka atbilstoši Civillikuma 1533. pantam par galīgi nodibinātu nomas līguma saturu un būtiskās sastāvdaḷas, tai skaitā parāda, apmēru un samaksas termiṇu var runāt vien pēc sprieduma spēkā stāšanās [61].

\section{Prasijuma tiesību noilgums}

Kā analizējot saistības izcelšanās pamatu un prasījuma tiesību rašanās brīdi, tāpat arī analizējot prasījuma tiesību noilguma jautājumus, ir jānošḳir prasījumi par nomas attiecību konstatēšanu un nomas līguma noslēgšanu no prasījumiem par nomas maksas samaksu. Prasījuma tiesību noilguma termiņš sāk tecēt tikai tad, kad prasījums ir nodibināts, proti, prasījuma tiesības ir radušās. Prasījuma tiesību noilguma termiṇa tecējumu pārtrauc atgādinājums gan dzīvokḷa īpašniekam, gan pilnvarotajam ēkas pārvaldniekam.

Vispārējais saistību tiesības un prasības tiesības noilguma regulējums ir ietverts Civillikumā. Saskaṇā ar Civillikuma 1893. pantu saistību tiesības izbeidzas, ja tiesīgā persona tās pienācīgi neizlieto likumā noteiktajā noilguma termiṇā. Vispārējais noilguma termin,š ir noteikts Civillikuma 1895. pantā, un paredzēts, ka visas saistību tiesības, kuras nav noteikti izn,emtas no noilguma ietekmes un kuru izlietošanai nav likumā noteikti īsāki termiṇi, izbeidzas, ja tiesīgā persona tās neizlieto desmit gadu laikā. İsāki noilguma termini ir noteikti attiecībā uz komersantu veiktajiem komercdarijumiem. Komerclikuma 406. pantā [6] paredzēts triju gadu noilgums prasijumiem, kas izriet no komercdarïjuma tiesības prasit līguma izpildi.

Civillikuma 1910. pantā noteikts, ka ar noilguma termiṇa notecējumu izbeidzas ne vien prasības tiesība, bet arī pati saistību tiesība, secīgi likumdevējs šìs abas tiesības ir nodalïjis un pakārtojis vienu otrai. Par to liecina arī Civillikuma 1896. panta formulējums: "Noilgums sāk tecēt ar to dienu, kurā prasījums ir tā nodibināts, ka pret parādnieku, kas nav izpildījis savu pienākumu, nekavējoties var celt prasību, kaut arī tomēr vēl nebūtu ne parādnieks liedzies izpildīt, ne arī kreditors viṇam to atgādinājis."

Civillikuma 1402. pantā noteikts, ka saistību tiesības rodas no tiesiska darījuma vai no neatḷautas darbỉbas, vai pēc likuma. Civillikuma 1895. pantā paredzētais 10 gadu noilguma termiņš attiecas uz ikvienu prasījumu neatkarīgi no tā rašanās pamata. Savukārt Komerclikuma D dạ̦ā, tajā skaitā Komerclikuma 406. pantā, ietvertais regulējums par prasības noilgumu attiecas tikai uz saistībām, kas izriet no tiesiska darījuma (komercdarījuma). 
Piespiedu zemes nomas tiesiskās attiecības tiek nodibinātas bez pušu gribas - saistîbu tiesība zemes un ēkas īpašnieka starpā ir nodibinājusies ar brīdi, kad abas puses ir ieguvušas īpašuma tiesības uz attiecīgi zemes un ēkas īpašumu, šajā brīdī rodoties zemes īpašnieka tiesībām celt prasību par nomas līguma noslēgšanu, nomas maksas noteikšanu, kā arī par nomas maksas piedziṇu.

Nomas tiesiskās attiecības var nodibināt arī noslēdzot rakstveida līgumu un vienojoties par nomas būtiskajām sastāvdaḷām (Civillikuma 2124. pants), kā arī nomas maksas samaksas termiṇiem. Šajā gadỉjumā prasījuma tiesības par līguma izpildi un maksājumu piedziṇu zemes īpašniekam rodas brīdī, kad nomnieks kavē pielīgtos samaksas terminusus, un šajā brīdī sāk tecēt arī noilgums šim prasījumam. Nepastāvot rakstveida līgumam, lìdz 2009. gada 1. novembrim nebija pamata runāt par nodibinātu, no nomas līguma izrietošu prasījumu par naudas samaksu, jo tiesību normās nebija noteikts precīzs zemes nomas maksas apmērs. Tāpēc atbilstoši Civillikuma 1533., 2124. un 2125. pantam nebija pamata konstatēt, ka pušu starpā būtu panākta kāda vienošanās par darỉjuma būtisku sastāvdaḷu, proti, nomas maksu. Savukārt attiecībā uz otru līguma būtisko sastāvdaḷu (nomas priekšmetu) likumā "Par valsts un pašvaldību dzīvojamo māju privatizāciju" tā imperatīvi tika noteikta tikai ar grozījumiem, kas stājās spēkā 2014. gada 1. oktobrī. Šì skaidrojošā norma attiecināma arī uz Dzīvojamo māju pārvaldīšanas likumā minēto "piesaistāmo zemesgabalu", tādējādi par nodibinātām zemes piespiedu nomas līguma būtiskajām sastāvdaḷām var runāt vien ar 2014. gada 1. oktobri [54].

Ja pušu starpā nepastāv vienošanās par nomas līguma būtiskajām sastāvdaḷām, tas vien, ka no absolūto (īpašuma) tiesību nostiprināšanas un piespiedu nomas attiecību rašanās brīža ir pagājuši vairāk nekā 10 gadi, neizbeidz piespiedu nomas tiesiskās attiecības pušu starpā vai no tām izrietošās tiesības un pienākumus. Zemes īpašniekam gan nav vairs prasijuma tiesību par zemes nomas maksas noteikšanu un nomas maksas piedziṇu par laiku, kas pārsniedz noilguma terminu - šobrīd Civillikumā norādìtos 10 gadus. Tomēr tas vien, ka zemes īpašnieks nav vērsies tiesā vai pie ēkas īpašnieka ar prasību par nomas attiecību konstatāciju vai līguma noslēgšanu, neliedz viņam to prasīt tagad un par iepriekšējiem 10 gadiem. Savukārt, ja pušu starpā ir noslēgts komercdarījums (piemēram, nomas līgums) un kreditors nav izmantojis savas no komercdarïjuma izrietošãs prasības tiesības par līguma izpildī̌nanu vairāk nekā trīs gadus, saistība, kas nodibināta ar komercdarījumu (nomas līgumu), šajā brīdī nav noilgusi, bet ir noilgusi tikai daḷa no prasījumiem, kas izriet no šĩs ar darījumu nodibinātās saistības.

Arī pēc 2014. gada 1. oktobra rakstveida nomas līguma neesamības gadījumā tiesību normas nesniedz viennozīmīgu atbildi uz būtisku jautājumu: no kura brīža skaitāms noilguma tecējuma sākums, proti, kad ir radusies zemes îpašnieka prasījuma tiesība par zemes nomas maksas samaksu (ir iestājies nodibināta prasijuma samaksas termiņ̧̌). Lai gan no 2014. gada 1. oktobra līdz 2018. gada 1. janvārim tiesību normās viennozīmīgi bija noteiktas abas zemes piespiedu nomas tiesisko attiecību būtiskās sastāvdaḷas, joprojām diskutabls ir jautājums, kad iestājas parāda samaksas termin̦š, ja puses par to nav vienojušās. Pēc Valsts ieñēmumu dienesta paustā, tas iestājas ar sprieduma spēkā stāšanās 
brīdi, jo tiesas spriedums aizstāj aktu, kas nodibina maksāšanas pienākumu [70]. Pastāvot strīdam, piemēram, par nomas maksas aprēḳinu vai nomas maksai papildu maksājamo pievienotās vērtības nodokli, darījumu nevar atzìt par galīgi noslēgtu ar īpašuma tiesību iegūšanas faktu vien, lai gan saistība (par tās būtiskajām sastāvdal̦ām pušu starpā vēl ir strīds, un prasījuma tiesība nav atzīstama par nodibinātu) jau pastāv [36].

\section{Komerctiesiskā noilguma piemērošana piespiedu nomā}

Prasījuma tiesības piespiedu nomā var rasties uz likuma pamata: tās ir tiesības prasìt nomas attiecību konstatāciju vai nomas līguma noslēgšanu. Laikā starp 2014. gada 1. oktobri un 2017. gada 31. decembri ar likumu tika nodibinātas arī tiesības prasīt nomas maksas samaksu bez prasījuma konstatēt nomas attiecību vai līguma esamību. Saistības, pastāvot piespiedu nomas attiecībām, var rasties arī uz darījuma pamata, ja pušu starpā pastāv rakstveida nomas līgums. Pastāvot rakstveida līgumam, strīdu par prasijuma tiesību nodibināšanos un noilgumu ir mazāk - ja kāda no pusēm ir komersants, ir pamats piemērot noilgumu, kas noteikts prasijumiem, kas izriet no komercdarïjuma. Ja prasījuma tiesības ir radušās uz likuma pamata, katrā gadījumā jāvērtēe, kā tās radušās un kāds ir to saturs.

Tiesu praksē ir nostiprinājies viedoklis, ka prasījumiem, kas izriet no zemes nomas tiesiskajām attiecībām, ja zemes īpašnieks (prasītājs) ir komersants, vienmēr ir piemērojams saīsinātais komerctiesiskais noilgums [40]. Komercdarïjumu regulējums tiek piemērots arī tad, ja vienošanās par nomas attiecību būtiskajām sastāvdaḷām zemes īpašnieka un èkas dzīvokḷu īpašnieku starpā nav panākta, proti, nav konstatējama darījuma noslēgšana. Tomēr kritiski ir vērtējama hipotēze, ka visās saistībtiesiskās attiecībās, kas ir komerctiesiska rakstura, jāpiemēro Komerclikuma 406. pants un nav nozìmes prasijuma rašanās pamatam [14; 57]. İpaši kritiski jāvērtē šì apgalvojuma attiecināšana uz prasījumiem, kas izriet no piespiedu nomas tiesiskajām attiecībām, kad "uz likuma un tiesas sprieduma pamata pusēm izveidojas līgumam līdzīgas attiecības, bet ne līgums" [20, 12.2. punkts].

Komerclikuma 406. pants ietverts Komerclikuma D dạ̦ā "Komercdarījumi", tātad, sistēmiski tulkojot, tas attiecināms uz komercdarījumiem. Lai piemērotu šo prasījuma tiesību noilguma terminu, vispirms nepieciešams konstatēt, ka starp pusēm ir noslēgts komercdarījums. Termina "komercdarījums" legāldefinīcija sniegta Komerclikuma 388. pantā, pietiekami skaidri norādot, ka "komercdarījumi" ir komersanta "tiesiskie darījumi", kas saistīti ar komercdarbību. Lai gan Komerclikumā nav sniegts jēdziena "tiesiskie darījumi" skaidrojums, no Komerclikuma 3. panta pirmās un otrās daḷas izriet, ka šā jēdziena skaidrojums meklējams Civillikumā, kura normas piemērojamas komercattiecībās, ja Komerclikums vai cits komercdarbību regulējošais likums attiecīgo jautājumu neregulē [30].

Prasījuma tiesības var rasties gan uz likuma, gan tiesiska darïjuma pamata. Par komercdarījumu var atzìt tikai tiesisku darījumu. Arī komersantam gan prasījuma tiesỉbas, gan samaksas pienākums var rasties gan uz likuma, gan neatḷautas darbỉbas, gan 
darïjuma pamata. Apgalvojums, ka Komerclikuma 406. panta tvērums attiecas uz ikvienu komersanta prasījumu, ir pārāk plašs. Judikatūrā norādīts, ka ir komersantu prasījumi, uz kuriem komerctiesiskais noilgums nav attiecināms, jo tie nav komercdarïjumi. Tādi, piemēram, ir prasījumi, kas izriet no pilnvarojuma līguma [13; 45]. Arī attiecībā uz ìpašuma prasībām nebūtu pamata piemērot komerctiesisko noilgumu. Šie ir prasījumi, kas radušies uz likuma pamata, līdzīgi kā prasījums par zemes nomas tiesisko attiecību konstatāciju un no tā izrietošais parāda piedziṇas prasījums. Tādējādi nav pamata pieṇēmumam, ka komerctiesiskais noilgums būtu piemērojams arī attiecỉbā uz prasỉjumiem, kas izriet no saistībām, kas nodibinātas uz likuma pamata. Arī gadījumos, ja kāda no nomas attiecību pusēm ir komersants (ēkas vai zemes īpašnieks vai viens no kopīpašniekiem ir komersants), ja šo nomas tiesisko attiecību un no tām izrietošo prasijumu pamats ir tikai likums, proti, darījums pušu starpā nav noslēgts, šìs zemes piespiedu nomas attiecības nevar uzskatìt par komercdarïjumu Komerclikuma 388. panta izpratnē [46].

Noilgums prasijuma tiesībām, kas izriet no saistības, kas radusies uz likuma pamata, nav atkarīgs no saistības subjekta (kreditora vai parādnieka) ierakstīšanas komercreǵistrā, bet ir atkarīgs no prasijuma tiesību rašanās pamata. Zemes īpašnieka motīviem, iegūstot īpašumā zemes gabalu, nav tiesiskas nozīmes, ja prasijuma tiesības neizriet no komercdarījuma [7]. Tāpat tiesiskas nozìmes attiecỉbā uz piespiedu nomas attiecībām nav arī dzīvokḷa īpašnieka motīviem, iegādājoties dzìvokḷa īpašumu. No Civillikuma 1449. panta izriet, ka darījuma iemesli darījuma spēku neietekmē. Darỉjuma motīvi ir attiecināmi uz sākotnējo, jau izpildīto darījumu vai administratīvo aktu, kura izpildes rezultātā ir zemesgrāmatā nostiprinātas zemes îpašnieka īpašuma tiesības [11].

Dzīvokḷa îpašnieks (privatizētājs vai tā ieguvējs) - neatkarīgi, vai tā ir juridiska vai fiziska persona - nav atzīstams par mazāk aizsargātu tiesiskās attiecības dalībnieku, kā tas būtu raksturīgi patērētāja un pakalpojumu sniedzēja attiecībās. Kā vienam, tā otram iespēja pārtraukt savstarpējās nomas tiesiskās attiecības ir, vienīgi atsavinot savu īpašumu. Abu pušu īpašuma tiesỉbas ir ierobežotas, un, iespējams, zemes īpašnieka īpašuma tiesību aprobežojums ir pat būtiskāks, jo viṇam faktiski nav iespējas lietot savu īpašumu un īpašuma tiesības reāli nav izlietojamas [60, 5]. Abu pušu griba ir ierobežota, kas nav raksturīgs komerctiesiskai attiecībai. Ja puses nav brīvprātīgi noslēgušas nomas līgumu, piespiedu noma pēc izcelsmes veida un pazīmēm nav atzīstama par darïjumu, vēl mazāk - par komercdarījumu [48].

Nevar atzit par juridiski korektu apgalvojumu, ka komersantam piespiedu nomas tiesiskās attiecības nav gluži uz likuma pamata radìtas saistību tiesības, bet vairāk ar līgumisku raksturu. Gluži pretēji, arī judikatūrā ir atzìts, ka "piespiedu nomas attiecības nav risināmas tipisku saistību tiesību ietvarā", jo īpašuma reformas rezultātā izveidojies zemes lietojums pastāv kā ar likumu noteiktas zemes īpašnieka tiesības saṇemt nomas maksu un èku ìpašnieka tiesības lietot zemi un pienākums veikt samaksu par lietoto nomas priekšmetu [18]. Jauktu saistības nodibināšanās pamatu Civillikuma 1402. pants neparedz. Likumdevējs ir izvēlējies ēkas un zemes īpašnieka tiesiskās attiecības regulēt atbilstoši nomas līguma noteikumiem, tāpēc šajās attiecībās ir līgumiskais elements, 
piemēram, jautājumā par būtiskajām nomas attiecību sastāvdaļām. Tomēr šis līgumiskais elements pats par sevi tiesiskās attiecības nepārvērš par darījumu.

\begin{abstract}
“Saskaṇā ar objektīvo sistēmu tiesiskais darījums ir atzīstams par komercdarījumu, ja tam piemīt pazīmes, kādas objektīvi raksturīgas komerctiesiskajā apgrozībā noslēgtam darījumam. [..] Komercdarījumā, tāpat kā jebkurā citā tiesiskā darījumā, saskaṇā ar Civillikuma 1427. pantu ir nepieciešams personas gribas izteikums. Ja noslēdzamais komercdarījums ir daudzpusējs tiesiskais darījums, piemēram, līgums, tā noslēgšanai ir nepieciešami saskanīgi visu dalïbnieku gribas izteikumi." [55]

“Zemes īpašnieka un daudzdzīvokḷu dzīvojamās mājas īpašnieku savstarpējās attiecības ir dalītā [..] rezultāts [..]. Šādos gadījumos ēkas īpašnieka un zemes īpašnieka savstarpējās tiesiskās attiecības par zemes lietošanu nodibina likums. Konkrētajā gadījumā komersants neizsaka savu gribu ne par zemes gabala platību, ne par maksājamo apmēru, to nosaka likums." [42]
\end{abstract}

Nav tiesiska pamata likuma normas, kas regulē tiesiskus darījumus un gribas izteikumus, pēc analog̣ijas piemērot arī uz likuma pamata nodibinātām civiltiesiskām attiecībām. Lai izmantotu analog̣iju, ir jāvērtē normas jēga un mērḳis, kā arī jākonstatē atklāts likuma robs - likuma plānam pretēja nepilnība [56, 129, 133].

Komerclikuma 406. panta tvēruma paplašināšana pēc analogijas un tā piemērošana arī "darījumiem līdzīgām attiecībām", kurās nav viennozīmīgi konstatējami darījuma elementi, to skaitā nedz darījuma noslēgšanas brīdis vai prasijjumu par maksājumu veikšanu rašanās brīdis, nonāk pretrunā Satversmes 105. pantam. Satversmes 105. pants ietver tiesības gūt no lietas visus iespējamos labumus, tostarp ienākumus un augḷus, un liedz ipašuma tiesības ierobežot uz analoǵijas pamata [50, 10. punkts; 51, 12. punkts]. Saīsināta noilguma termiṇa piemērošana prasījuma tiesībām ir atzīstama par īpašuma tiesību aprobežošanu. Nav piel̦aujams izmantot indukciju (argumentu no mazākā uz lielāko, no konkrētā uz vispārējo), paplašinot analogijas tvērumu, nepamatojot šo nepieciešamību.

No otras puses, Augstākā tiesa vairākās lietās ir atzinusi, ka tikai ar sprieduma spēkā stāšanās brīdi ir konstatējamas visas darījuma būtiskās sastāvdaḷas, un, ja vispār var runāt par darījuma noslēgšanu piespiedu nomas gadījumā, tas uzskatāms par noslēgtu, tikai stājoties spēkā šim spriedumam [17; 18]. Judikatūrā ir vienprātīgi atzīts, ka piespiedu nomas tiesisko attiecību pastāvēšanas gadījumā, kamēr pastāv strīds par maksājamo nomas maksu un parāda summas apmēru, nevar pat runāt par nomas maksas samaksas kavējumu [15]. Ja nav samaksas kavējuma, prasījums nevar noilgt. Tādējādi laikā, kamēr nav nodibināta parāda summa, zemes īpašniekam ir prasības tiesības par zemes nomas līguma būtisko sastāvdaḷu konstatāciju, un šis prasījums, kā vairums saistībtiesisko prasỉjumu, noilgst desmit gadu laikā.

Domājams, nemaz netiktu uzsākta diskusija par to, vai prasijumiem, kas izriet no piespiedu nomas tiesiskajām attiecībām, būtu jāpiemēro Komerclikuma normas, ja Civillikuma vispārējais noilgumu regulējums paredzētu īsākus prasības noilguma termiṇus. Lielā dal̦ā Eiropas valstu ir veikta civiltiesisko attiecību regulējošo tiesību normu 
modernizācija, tostarp saīsinot prasības noilguma terminuus [63, 14]. 10 gadu noilguma termin,š bija saprātīgs pirms 150 vai 100 gadiem, tomēr mūsdienu tiesiskās apgrozības ātrums liek padomāt, vai arī Latvijas likumdevējam nebūtu jāveic šo normu grozỉjumi, lìdz pieciem vai pat trim gadiem saīsinot termiṇu, kurā var realizēt arī uz likuma pamata radušās prasījuma tiesības.

No minētā izriet, ka nav pareizs secinājums, ka piespiedu nomas tiesiskajās attiecībās, ja vismaz viens no attiecību dalïbniekiem ir komersants, ir piemērojams Komerclikuma 406. pants, un nav nozìmes prasijuma rašanās pamatam. Prasījuma pamatam ir tiesiska nozìme, vērtējot prasījuma tiesību noilgumu. Vienlaikus, lai nodrošinātu regulējuma atbilstību mūsdienu civiltiesiskās apgrozības àtrumam, Civillikuma 1895. pants būtu jāgroza, nosakot, ka prasījuma tiesības noilgst, ja tās nav izlietotas triju gadu laikā.

\section{Noilguma tecējuma pārtraukums}

Atbilstoši Civillikuma 1905. pantam noilgumu pārtrauc atgādinājums parādniekam. Tāpat noilgumu pārtrauc arī prasības celšana tiesā, ja tiesā lieta tiek ierosināta [58]. Praksē strīdus rada jautājums, vai par atgādinājumu dzīvokḷa īpašniekam var uzskatīt èkas pārvaldniekam (dzīvokḷa īpašnieka pilnvarniekam) nosūtītu atgādinājumu. Par labu šim argumentam runā Augstākās tiesas atziñas lietā Nr. SKC-250/2017 [26], kā arī likuma "Par valsts un pašvaldību dzīvojamo māju privatizāciju" 54. panta ceturtās daḷas un Dzīvojamo māju pārvaldǐšanas likuma 6 . panta otrās daḷas 4 . punkta, $17 .^{2}$ panta otrās daḷas, 17. ${ }^{7}$ panta un pārejas noteikumu 17.-19. punkta sistēmiska interpretācija.

Attiecībā uz ēkām, kuras apsaimnieko vēl pašvaldības izraudzīts pārvaldnieks, Augstākā tiesa ir norādījusi, ka pašvaldības pilnvarojums atbilstoši likuma "Par valsts un pašvaldību dzīvojamo māju privatizāciju" normām nozīmē arī uzdevumu un pilnvarojumu slēgt zemesgabala nomas līgumus ar zemesgabala îpašniekiem [26]. Tā likuma 50. panta pirmās daḷas 3. punktā noteikts, ka dzīvokḷa ìpašnieka pienākums ir slēgt zemes nomas līgumu vai pilnvarot dzīvojamās mājas pārvaldītāju un apsaimniekotāju slēgt zemes nomas līgumu ar tā zemesgabala ỉpašnieku (fizisko vai juridisko personu), uz kura atrodas privatizētais objekts. Šā panta septītajā dal̦ā noteikts, ka valsts dzīvojamās mājas valdītāja vai pašvaldības pienākums ir pārvaldìt dzīvojamo māju līdz tās pārvaldīšanas tiesību nodošanai dzīvokḷu īpašnieku sabiedrībai vai ar dzīvokḷu īpašnieku savstarpēju līgumu pilnvarotai personai. Ja dzīvokḷu īpašnieki dzīvojamo māju savā pārvaldīšanā nav pārn̦ēmuši, tad pašvaldība, t. i., tās pilnvarotā persona, turpina pārvaldìt dzīvojamo māju dzīvokḷu īpašnieku vārdā, tostarp pildīt pienākumu slēgt nomas līgumu ar zemes īpašnieku. Pašvaldība, vai precīzāk - tās vietnieks (piemēram, pašvaldības kapitālsabiedrības, kas izveidotas privatizēto ēku pārvaldīšanai) ir atzīstams par dzīvokḷu īpašnieku pilnvarnieku. Vēršanās ar atgādinājumu vai tiesā pret ēkas pārvaldnieku atbilstoši likuma "Par valsts un pašvaldību dzìvojamo māju privatizāciju" 54. panta ceturtās daḷas prasībām pārtrauc jebkādu noilgumu - gan saistību, gan prasības noilgumu. 
Šis princips attiecināms arī uz ēkas dzīvokḷu īpašnieku pilnvaroto personu, ja ēkas īpašnieki ir pārṇēmuši ēkas apsaimniekošanu. Dzīvojamo māju pārvaldīšanas likuma 6. panta otrās dal̦as 4. punktā noteikts, ka zemes nomas līguma slēgšana ir obligātā pārvaldīšanas darbība, savukārt 17. ${ }^{7}$ pantā dotas vispārējas norādes, ka zemes nomas līgums jāslēdz, ievērojot Civillikuma, citu likumu, kā arī šā likuma $17 .^{2}$ panta, izṇemot tā ceturto daḷu, noteikumus. Likuma $17{ }^{2}$ panta otrajā dạ̦ā paredzēts, ka dzīvokḷu ỉpašnieki pilnvaro vienu personu, kas var būt arī pārvaldnieks, pakalpojuma līguma noslēgšanai. Pilnvarotā persona slēdz pakalpojuma līgumu visu dzīvojamās mājas ỉpašnieku vārdā. Tā kā likuma pārejas noteikumu 17.-19. punktā noteikts, ka dzīvokḷu īpašniekiem vai pārvaldniekam ir jāinformē pakalpojumu sniedzējs (tātad arī zemes īpašnieks), izdarot izvēli par labu tiešajiem maksājumiem, zemes ìpašnieks atbilstoši minētajām tiesību normām var prezumēt, ka līdz šāda paziṇojuma saṇemšanai ēku pārvaldniekam ir tiesības slēgt zemes nomas līgumu ēkas ìpašnieku vārdā, secīgi pārvaldnieks ir atzīstams par pilnvarnieku (Dzīvojamo māju pārvaldīšanas likuma 11. panta pirmā daḷa, kurā noteikts, ka pārvaldī̌sanas tiesiskajās attiecībās, ciktāl tās neregulē šis likums, piemērojami Civillikuma noteikumi par pilnvarojuma līgumu, Civillikuma 2289. un 2306. pants) vai lietvedi (Civillikuma 2342. pants, kurā noteikts, ka pārstāvamā attiecības pret trešām personām, ar kurām lietvedim bijusi darǐšana, nosaka vispārējie noteikumi par vietniekiem), un atgādinājums pilnvarniekam vai lietvedim ir atzīstams par atgādinājumu pašam parādniekam.

Vēršanās ar pretenziju vai vēršanās tiesā pret ēkas pārvaldnieku pārtrauc jebkādu noilgumu - gan saistību, gan prasības noilgumu, ja vien dzīvokḷu îpašnieki nav paziņojuši zemes īpašniekam par izvēli veikt tiešos norēḳinus. Atbilstoši Civillikuma 1902. pantam saistības un prasības noilgumu pārtrauc tiesības izlietošana, ceḷot prasību tiesā, savukārt saistības noilgumu pārtrauc jebkurš atgādinājums parādniekam (Civillikuma 1905. pants) vai tā pārstāvim (Civillikuma 2298. pants, Dzīvojamo māju pārvaldīšanas likuma 11. pants, likuma "Par valsts un pašvaldību dzīvojamo māju privatizāciju" 50. panta pirmās daḷas 3. punkts un 54. panta ceturtā daḷa).

\section{Secinājumi}

1. Zemes īpašnieka prasījuma tiesības par zemes nomas tiesisko attiecību konstatāciju rodas no īpašuma tiesību nostiprināšanas zemesgrāmatā brīža par laikposmu no valdījuma iegūšanas brīža.

2. Prasijuma tiesības, kas izriet no jau noslēgta nomas līguma izpildes, rodas brīdī, kad prasījums ir tā nodibināts, lai varētu prasìt tā izpildi, t. i., nepastāvot pušu brīvprātīgam līgumam - no sprieduma, ar kuru nodibinātas nomas tiesisko attiecību būtiskās sastāvdal̦as, spēkā stāšanās brīža. Ar sprieduma spēkā stāšanās brīdi ir konstatējamas visas tiesiska darỉjuma būtiskās sastāvdal̦as un darījums uzskatāms par galīgi noslēgtu, un zemes īpašniekam ir radušās prasījuma tiesības par šì darïjuma izpildi - tiesības prasīt zemes nomas maksas samaksu. 
3. Prasījuma tiesības par zemes nomas tiesisko attiecību konstatāciju pret personu, kas veic daudzdzīvokḷu ēkas pārvaldīšanu un apsaimniekošanu, zemes īpašniekam rodas no brī̌za, kad pārvaldnieks ir pārṇēmis konkrētās ēkas pārvaldī̌̌anu un apsaimniekošanu, vai no zemes īpašuma tiesỉbu iegūšanas brǐža, atkarībā no tā, kas iestājies pēdējais. Tādas pašas prasījuma tiesības ir pārvaldniekam pret zemes īpašnieku, ja tas ir publiskas personas iecelts vai atbilstoši pilnvarots no dzīvokḷu ìpašnieku puses.

4. Prasījuma tiesības par zemes nomas tiesisko attiecỉbu konstatāciju pret atseviškiem dzīvokḷu īpašniekiem zemes īpašniekam ir radušās tikai kopš 2015. gada 1. oktobra, kad likums piel̦auj pakalpojumu sniedzējiem pieprasìt tiešos maksājumus no dzīvokḷ îpašniekiem par ēkas uzturēšanai nepieciešamajiem pakalpojumiem.

5. Nav tiesiskas nozīmes tam, uz kāda pamata zemes īpašnieks ir ieguvis īpašuma tiesības uz zemesgabalu, jo šis darïjums vai administratīvais akts ir izpildîts ar brīdi, kad ieguvēja īpašuma tiesības tika nostiprinātas zemesgrāmatā. Zemes īpašnieka tiesības prasìt nomas maksu izriet no lietu tiesības - ipašuma tiesībām uz zemesgabalu.

6. Prasījuma tiesību par zemes nomas maksas samaksu noilgumu pārtrauc gan atgādinājums vai vēršanās tiesā pret atsevišḳu dzīvokḷa īpašnieku, gan arī atgādinājums vai vēršanās tiesā pret ēkas pārvaldnieku, jo pēdējais, ja vien dzīvokḷu īpašnieki nav paziņojuši zemes ìpašniekam par izvēli veikt tiešos norēḳinus, ir uzskatāms par dzīvokḷu īpašnieku pilnvarnieku vai lietvedi.

\section{Limitation Period for Claims Arising from Compulsory Land Lease}

\section{Abstract}

After the restoration of the independence of the Republic of Latvia, within the framework of the initiated land reform, the legislature restored property rights of former owners or their heirs to the land which apartment houses were built on during the Soviet times, thus creating the basis for the so-called divided ownership. Legislator made a decision to regulate relationships between landowners and building owners as lease agreement. Although the legal relationship of compulsory land lease is established by law - the norms included in the law "On Land Reform in the Cities of the Republic of Latvia" and the law "On Privatisation of State and Local Government Residential Houses", there are different opinions as to whether legal relations between the parties could be classified as a legal transaction, or furthermore - as a commercial transaction, and, consequently, whether claims arising from compulsory land lease relations arise from the law or from a transaction. 
The aim of the research is to identify the moment when the right to claim has been established, which is a prerequisite for establishing the moment when the limitation period of the claim begins. It has been concluded in the research that it is necessary to distinguish between two claims a landowner can have: a claim to establish a legal relationship of land lease (conclude an agreement) and the claim in respect to execution of a concluded lease agreement - payment of the lease fee. The latter arises only after the conclusion of the agreement - either voluntarily or through the court; the limitation period for the claim arising from the concluded lease agreement begins at that moment.

The interpretation of legal norms and analysis of legal doctrine and judicature in the research resulted in the conclusion that the claim to bring an action to conclude a land lease contract against the manager of the apartment house rises for the landowner at the moment the manager has taken over the management of the respective house, or at the moment the land property rights were acquired, whichever comes last, while the claim to conclude a land lease contract against individual apartment owners for the landowner arose only after October 1, 2015, when the law allowed to request direct payments from apartment owners for the services required for maintenance of the building.

Keywords: compulsory land lease, transaction, commercial transaction, right to claim, claim, limitation period, commercial limitation period.

\section{Avoti un literatūra}

\section{Tiesību akti}

1. Civillikums. Ceturtā daḷa. Saistību tiesības: Latvijas Republikas likums: pieṇemts 28.01.1937. un spēkā no 01.03.1993. Valdības Vēstnesis. 46, 26.02.1937.

2. Dzīvojamo māju pārvaldīšanas likums: Latvijas Republikas likums: pieṇemts 04.06.2009. un spēkā no 01.01.2010. Latvijas Vēstnesis. 96(4082), 19.06.2009.

3. Dzīvokḷa ìpašuma likums: Latvijas Republikas likums: pieṇemts 28.10.2010. un spēkā no 01.01.2011. Latvijas Vēstnesis. 183(4375), 17.11.2010.

4. Grozījumi Dzīvojamo māju pārvaldīšanas likumā: Latvijas Republikas likums: pieṇemts 19.12.2013. un spēkā no 15.01.2014. Latvijas Vēstnesis. 6(5065). 09.01.2014.

5. Grozījumi likumā "Par valsts un pašvaldību dzīvojamo māju privatizāciju": Latvijas Republikas likums: pieṇemts 19.06.2014. un spēkā no 01.10.2014. Latvijas Vēstnesis. 131(5191), 08.07.2014.

6. Komerclikums: Latvijas Republikas likums: pieṇemts 13.04.2000. un spēkā no 01.01.2002. Latvijas Vēstnesis. 158/160(2069/2071), 04.05.2000.

7. Par iedzīvotāju ienākuma nodokli: Latvijas Republikas likums: pieṇemts 11.05.1993. un spēkā no 01.01.1994. Latvijas Vēstnesis. 32, 01.06.1993.

8. Par valsts īpašumu un tā konversijas pamatprincipiem: Latvijas Republikas Augstākās Padomes lēmums: pieṇemts 20.03.1991. un spēkā no 20.03.1991. Ziṇotājs. 19/20, 23.05.1991.

9. Par valsts un pašvaldību dzìvojamo māju privatizāciju: Latvijas Republikas likums: pieṇemts 21.06.1995. un spēkā no 25.07.1995. Ziņotājs. 16, 24.08.1995.

10. Par zemes reformu Latvijas Republikas pilsētās: Latvijas Republikas likums: pieṇemts 20.11.1991. un spēkā no 20.11.1991. Ziṇotājs. 49/50,19.12.1991.

11. Zemesgrāmatu likums: Latvijas Republikas likums: pieṇemts 22.12.1937. un spēkā no 05.04.1993. Ziṇotājs. 16, 29.04.1993. 


\section{Tiesu prakse}

12. Augstākās tiesas Civillietu departamenta 2014. gada 19. decembra lēmums lietā Nr. SKC3112/2014 (materiāli Nr. 3-10/0028).

13. Augstākās tiesas Civillietu departamenta 2015. gada 29. maija lēmums lietā Nr. SKC-2288/2015 (materiāli Nr. 3-10/0169/14).

14. Augstākās tiesas Civillietu departamenta 2015. gada 9. novembra spriedums lietā SKC-160/2015 (C27127610).

15. Augstākās tiesas Civillietu departamenta 2016. gada 4. marta spriedums lietā Nr. SKC-40/2016 (C27197411).

16. Augstākās tiesas Civillietu departamenta 2016. gada 20. aprīḷa spriedums lietā Nr. SKC-5/2016 (C29859011).

17. Augstākās tiesas Civillietu departamenta 2016. gada 26. oktobra spriedums lietā Nr. SKC336/2016 (C39057712).

18. Augstākās tiesas Civillietu departamenta 2016. gada 3. novembra spriedums lietā Nr. SKC255/2016 (C17116307).

19. Augstākās tiesas Civillietu departamenta 2016. gada 22. novembra spriedums lietā Nr. SKC226/2016 (C30458513).

20. Augstākās tiesas Civillietu departamenta 2016. gada 20. decembra spriedums lietā Nr. SKC349/2016 (C15248612).

21. Augstākās tiesas Civillietu departamenta 2016. gada 30. decembra spriedums lietā Nr. SKC343/2016 (C30208807).

22. Augstākās tiesas Civillietu departamenta 2017. gada 31. janvāra spriedums lietā Nr. SKC-11/2017 (C37068613).

23. Augstākās tiesas Civillietu departamenta 2017. gada 31. janvāra spriedums lietā Nr. SKC-69/2017 (C30171108).

24. Augstākās tiesas Civillietu departamenta 2017. gada 30. jūnija spriedums lietā Nr. SKC-244/2017 (C27128613).

25. Augstākās tiesas Civillietu departamenta 2017. gada 27. septembra spriedums lietā Nr. SKC180/2017 (C39069012). ECLI:LV:AT:2017:0927.C39069012.1.S.

26. Augstākās tiesas Civillietu departamenta 2017. gada 5. oktobra spriedums lietā Nr. SKC-250/2017 (C24186312), ECLI:LV:AT:2017:1005.C24186312.1.S.

27. Augstākās tiesas Civillietu departamenta 2017. gada 18. oktobra spriedums lietā Nr. SKC234/2017 (C39069114). ECLI:LV:AT:2017:1018.C39069114.1.S.

28. Augstākās tiesas Civillietu departamenta 2017. gada 6. novembra spriedums lietā Nr. SKC338/2017 (C30578513), ECLI:LV:AT:2017:1106.C30578513.1.S.

29. Augstākās tiesas Civillietu departamenta 2017. gada 8. decembra spriedums lietā Nr. SKC305/2017 (C39094314), ECLI:LV:AT:2017:1208.C39094314.1.S.

30. Augstākās tiesas Civillietu departamenta 2017. gada 19. decembra spriedums lietā Nr. SKC344/2017 (C33269614). ECLI:LV:AT:2017:1219.C33269614.1.S.

31. Augstākās tiesas Civillietu departamenta 2017. gada 20. decembra spriedums lietā Nr. SKC268/2017 (C30738312). ECLI:LV:AT:2017:1220.C30738312.1.S.

32. Augstākās tiesas Civillietu departamenta 2018. gada 15. marta lēmums lietā SKC-415/2018 (C32116205), ECLI:LV:AT:2018:0315.C32116205.2.L.

33. Augstākās tiesas Civillietu departamenta 2018. gada 27. jūnija spriedums lietā Nr. SKC-5/2018 (C39102313), ECLI:LV:AT:2018:0627.C39102313.1.S. 
34. Augstākās tiesas Rīcības sēdes 2015. gada 23. jūlija lēmums lietā SKC-1062/2015 (C39057712). 35. Augstākās tiesas Senāta Civillietu departamenta 2007. gada 29. augusta spriedums lietā Nr. SKC-535/2007.

36. Augstākās tiesas Senāta Civillietu departamenta 2007. gada 7. novembra spriedums lietā Nr. SKC-712/2007.

37. Augstākās tiesas Senāta Civillietu departamenta 2009. gada 25. februāra spriedums lietā Nr. SKC$71 / 2009$ (C33186205).

38. Augstākās tiesas Senāta Civillietu departamenta 2010. gada 15. septembra spriedums lietā Nr. SKC-174/2010 (C04355106).

39. Augstākās tiesas Senāta Civillietu departamenta 2011. gada 13. aprīḷa spriedums lietā Nr. SKC-43/2011.

40. Augstākās tiesas Senāta 2019. gada 30. maija spriedums lietā Nr. SKC-104/2019. ECLI:LV:AT:2019:0530.C30524615.3.S.

41. Augstākās tiesas Senāta 2019. gada 28. jūnija spriedums lietā Nr. SKC-3/2019 (C39101313). ECLI:LV:AT:2019:0628.C39101313.1.S.

42. Dobeles rajona tiesas 2017. gada 17. oktobra spriedums lietā Nr. C30452117.

43. Kurzemes apgabaltiesas Civillietu tiesu kolēgijas 2017. gada 19. decembra spriedums lietā Nr. C30471317, ECLI:LV:KUAT:2017:1219.C30471317.6.S.

44. Rīgas apgabaltiesas Civillietu tiesu kolēǵijas 2014. gada 24. februāra spriedums lietā Nr. C24114213.

45. Rìgas apgabaltiesas Civillietu tiesu kolēgijas 2017. gada 13. februāra spriedums lietā Nr. C30673715.

46. Rìgas apgabaltiesas Civillietu tiesas kolēgijas 2018. gada 26. oktobra spriedums lietā Nr. C31235916,

47. Rīgas pilsētas Vidzemes priekšpilsētas tiesas 2018. gada 3. maija spriedums lietā Nr. C32195817, ECLI:LV:RVPT:2018:0503.C32195817.3.S.

48. Rīgas rajona tiesas 2018. gada 16. marta spriedums lietā Nr. C33448217.

49. Satversmes tiesas 2009. gada 13. februāra spriedums lietā Nr. 2008-34-01. Latvijas Vēstnesis. 27(4013), 18.02.2009.

50. Satversmes tiesas 2009. gada 15. aprīla spriedums lietā Nr. 2008-36-01. Latvijas Vēstnesis. 60(4046), 21.04.2009.

51. Satversmes tiesas 2011. gada 27. janvāra spriedums lietā Nr. 2010-22-01. Latvijas Vēstnesis. 17(4415), 01.02.2011.

52. Satversmes tiesas 2011. gada 25. oktobra spriedums lietā Nr. 2011-01-01. Latvijas Vēstnesis. 171(4569), 28.10.2011.

53. Vidzemes rajona tiesas 2018. gada 23. aprīḷa spriedums lietā Nr. C33461617, ECLI:LV:VRT:2018:0423.C33461617.4.S.

54. Zemgales apgabaltiesas 2016. gada 21. aprīḷa lēmums, lietas arhīva Nr. CA-0235-16/13.

\section{Literatūra}

55. Balodis, K. 2009. Jaunais komercdarījumu regulējums un tā piemērošana. Jurista Vārds. 21(564).

56. Kalniņš, E. 2003. Tiesību tālākveidošana. No: Juridiskās metodes pamati. 11 soḷi tiesību normu piemērošanā: Rakstu krājums. Zin. red. E. Mel̦kisis. Rīga: Latvijas Universitāte.

57. Kārkliṇš, J. 2018. Noilgums piespiedu nomas attiecībās komerctiesībās. Jurista Vārds. 9(1015), 14.-19. lpp. 
58. Odiṇš, R. 2018. Par Civillikuma 1903. panta saturu. Latvijas Republikas Augstākās Tiesas Biletens. 16, 112.-114. lpp.

59. Rozenfelds, J. 2000. Lietu tiesības. Rīga: Zvaigzne ABC.

60. Rozenfelds, J. 2008. Pētījums par Civillikuma Lietu tiesību daḷas (ceturtās, piektās, sestās un septītās nodaḷas) modernizācijas nepieciešamību. Iegūts no: http://www.tm.gov.lv/files/archieve/ lv_documents_petijumi_cl_ceturta_piekta_sesta_un_septita_nodala.doc [sk. 30.09.2013.].

61. Snipe, A. 2018. Par saistības un prasības noilgumu saistībai, kas radusies uz likuma pamata. Jurista Vārds. 40(994), 23.-25. lpp.

62. Snipe, A. 2018. Satversmes tiesas konsekventā cinna ar Saeimas populismu. Jurista Vārds. 23(1029), 22.-29. lpp.

63. Swiss Insititute of Comparative Law. 2011. Gutachten zum Recht der Verjährung Deutschland, Frankreich, England und Dänemark. Avis 10-225, Lausanne. Iegūts no: https://www.bj.admin.ch/ $\mathrm{dam} / \mathrm{data} / \mathrm{bj} /$ wirtschaft/gesetzgebung/verjaehrungsfristen/gutachten-sir-d.pdf [sk. 26.06.2019.].

64. Torgāns, K. 2014. Saistību tiesības. Rīga: Tiesu namu aǵentūra.

65. Vīnzarājs, N. 2000. Civiltiesību problēmas. Raksti (1932.-1939.). Rīga: E. Kalniṇa un V. Tihonova izdevums.

\section{Interneta resursi}

66. Bērtule, A. 21.07.2017. Ieilgušas tiesvedības dēḷ no 700 dzīvokḷu īpašniekiem grib piedzìt parādu par zemes nomu. LSM.LV Iegūts no: https://www.lsm.lv/raksts/zinas/latvija/ieilgusastiesvedibas-del-no-700-dzivoklu-ipasniekiem-grib-piedzit-paradu-par-zemes-nomu.a220157/ [sk. 13.06.2018.].

67. Daudzdzīvokḷ namu īpašniekiem prasa samaksāt 10 gadus vecu nomas maksas parādu par zemi. LETA. TVNET.LV 27.02.2017. Iegūts no: https://www.tvnet.lv/4586821/daudzdzivoklu-namuipasniekiem-prasa-samaksat-10-gadus-vecu-nomas-maksas-paradu-par-zemi [sk. 13.06.2018.].

68. Informācija patērētājiem par SIA "Vienotais norēḳinu centrs" un AS "Pilsētas zemes dienests" darbību, pieprasot zemes nomas parādus. Patērētāju tiesību aizsardzības centra informācija patērētājiem. Patērētāju tiesību aizsardzības centrs. 2017. Iegūts no: http://ptac.gov.lv/lv/news/ informacija-pateretajiem-par-sia-vienotais-norekinu-centrs-un-pilsetas-zemes-dienests-darbibu [sk. 13.06.2018.].

69. Par atzinumu pārbaudes lietā Nr. 6-6/236. Latvijas Republikas Tiesībsargs. 26.08.2010. Iegūts no: https://ej.uz/CPL77 [sk. 13.06.2018.].

70. Par uzziṇas sniegšanu Nr. 8.11-20/63149. VID uzziṇas, vēstules. Valsts ieṇēmumu dienests. 01.08.2014. Iegūts no: https://www.vid.gov.lv/lv/vid-uzzinas-vestules [sk. 13.06.2018.].

71. Piespiedu nomas tiesisko attiecību aktuālie jautājumi. LR Tieslietu ministrijas informācija presei. Latvijas Republikas Tieslietu ministrija. 21.03.2017. Iegūts no: https://www.tm.gov.lv/ lv/aktualitates/tm-informacija-presei/piespiedu-nomas-tiesisko-attiecibu-aktualie-jautajumi-2 [sk. 15.05.2018.]. 
https://doi.org/10.25143/socr.13.2019.1.096-103

\title{
leskats delikta tiesībās
}

\author{
Dana Segale \\ Rïgas Stradiña universitāte, Latvija \\ danasegale@inbox.lv
}

\section{Kopsavilkums}

Rakstā tiek aplūkotas delikta tiesības, parādot paša jēdziena vēsturisko un mūsdienu piepildījumu, kā arī dodot plašāku ieskatu šajā jautājumā, proti, analizējot problēmas, kas saistītas ar aizsardzību pret nepamatotu personas tiesību aizskārumu, un sniedzot to risinājumus.

Pētījumā ir analizēts tiesību aizskāruma un atlīdzinājuma vērtējums, stingri ievērojot šādu aspektu: atlīdzinājums pēc savas būtības nevar tikt uzskatīts par iespēju piepelnīties, un to nedrīkst noteikt, vērtēšanā izmantojot kādu matemātisku formulu. Šeit arī apskatīta mūsdienās pastāvošā problēma (vai drīzāk vēlēšanās, kura ir pāraugusi problēmā) visu noteikt naudas izteiksmē.

Atslēgvārdi: delikta tiesības, apmierinājums, tiesību aizskārums.

\section{levads}

Jebkādu zinātnisko izpēti sākot, pamatoti ir jāpiekrīt Reimonda Hartmana (Raymond Hartman) atziṇai, ka zinātne nav kas vairāk kā formālas atskaites sistēmas piemērošana fenomena haosam. Veicot fenomena, šajā gadijjumā delikta tiesību, izpēti ir jāpatur prātā, ka fakti un skaidrojumi, kuri atklāj izzināmā fenomena saturu, ir tikai šì brīža aktuālās atskaites sistēmas apskats, kurš pakḷauts nemitīgai attīstībai un pārmaiṇām.

Šã pētījuma mērḳis ir aplūkot delikta tiesības, parādot paša jēdziena vēsturisko un mūsdienu piepildījumu, kā arī dodot plašāku ieskatu šajā jautājumā, proti, pievēršoties problēmām, kas saistìtas ar aizsardzību pret nepamatotu personas tiesību aizskārumu, un to risinājumiem.

Šā pētỉjuma gaitā tika izmantota teorētiskā pamatojuma metode, ar kuras palīdzību analizēta tiesību doktrīna, kā arī analītiskā metode. Tika salīdzinātas tiesību normas un dažādu autoru atziņas, kā arī salīdzināts tiesiskais regulējums normatīvo aktu un juridiskās literatūras aspektā, veikta analīze un apkopošana, lietojot aprakstošo metodi. 


\section{Jēdziena "delikts" vēsturiskais aspekts}

Pētot delikta tiesību izveidošanos, vispirms jāpievēršas romiešu tiesību analīzei delikta tiesību aspektā, jo tieši romiešu tiesībās tika ieviests šã fenomena skaidrojums un dots tam nosaukums, kas saglabājies līdz mūsdienām.

Romieši lietoja divus tiesību pārkāpumu apzīmējumus - crimen jeb noziegums un delietum jeb neatḷauta darbība. XII tabulu likumos ir paredzēti vairāki delikti. Visnopietnākais no tiem - iniuria jeb personas apdraudējums. Ja par šādu nodarījumu starp cietušo un uzbrucēju netika panākts izlīgums, tad rīkojās pēc taliona principa, t. i., "zobs pret zobu, acs pret aci”. Turpretī gadījumā, ja cietušajam bija lauzti kauli, pārsista galva vai ievainots vēders, XII tabulu likumi aizliedza rīkoties pēc taliona principa. Vainīgajam vajadzēja samaksāt cietušajam 300 asu; bet, ja cietušais bija vergs, tad par šādu pašu nodarījumu sods bija 150 asu (naudu san̦ēma verga īpašnieks). Par piekaušanu cietušajam pienācās 25 asis. [8]

Vēlākos laikos mainījās izpratne par neatḷautās darbības smaguma pakāpi, un atsevišḳi tika izdalītas neaț̣autās darbības ar smagām sekām. Tās uzskatỉja par noziegumiem, jo mainījās uzskats par dzīvības un veselības vērtību.

XII tabulu likumos bija paredzēti vēl citi delikti, mazāk nozīmīgi. Klasiskajā laikmetā romiešu tiesībās no noziedzīga nodarỉjuma zādzības (latīṇu valodā furtum) atsevišḳi tika nošķirta laupī̌sana (rapina). Delikti jeb tiesību pārkāpumi kā saistību izcelšanās pamats saglabājās arī Romas impērijas pēdējos gadsimtos. Tiesību pārkāpumiem, kurus joprojām sauca par iniuria, prētoriskajās tiesībās (ius praetorium) tika sašaurināts to saturs, atsakoties no taliona principa piemērošanas personas aizskāruma gadījumos. Prētoriskajās tiesībās bija paredzēts, ka par personas aizskārumu vajadzēja atlīdzināt ar likumā noteiktu naudas summu. [8]

Šis ieskats romiešu tiesībās l̦auj skaidri secināt, ka delikta regulējumā tika ietvertas konkrētas naudas summas par konkrētiem tiesību pārkāpumiem, un tas ir pretēji mūsdienu tiesu praksei un normatīvajam regulējumam. Mūsdienu izpratne par šo jautājumu labi ir redzama Augstākās tiesas apkopojumā sniegtajos skaidrojumos, proti, ka atlīdzības apmērs, piemēram, par morālo kaitējumu nosakāms katrā konkrētā gadījumā pēc tiesas ieskata, vadoties pēc taisnības apzinnas un vispārīgiem tiesību principiem. Jānem vērā, ka nepastāv vienota likme, lai noteiktu atlīdzības apmēru par morālo kaitējumu. To nosaka, n̦emot vērā morālā kaitējuma smagumu, raksturu, tā nodarīšanas apstākḷus un sekas, kā arī citus būtiskus apstākḷus. Piespriežamai summai jeb atlīdzinājumam jāpilda taisnīguma, prevencijas un samierināšanas funkcija. Atlīdzinājumam ne tikai jāsniedz mierinājums personai, kuras tiesības tikušas aizskartas, bet arī jāattur vainojamā persona no līdzīgu aizskārumu izdarīšanas nākotnē. Tādējādi atlīdzinājumam jābūt samērīgam. [11] 


\section{Atlīdzības apmēra noteikšanas izpratne}

Jautājums par atlīdzības apmēru vienmēr ir bijis aktuāls, un, izpētot judikatūru, nav pat manāma kāda konsekvence vai vienotas vadlīnijas apmierinājuma noteikšanā, vērtēšanā vai lielumā.

Tomēr, vērtējot jēdziena "delikts" mūsdienu izpratni, var atrast dažādus skaidrojumus, piemēram, tā ir neatbilstīga darbība vai bezdarbỉba, par kuru cietusī persona civilā procesā var prasìt zaudējumu piedziṇu, ja vien šĩ neatbilstīgā darbība nav tikai līguma pārkāpums. Civiltiesību pārkāpumu tiesības galvenokārt attiecas uz kompensāciju piešḳiršanu par personisku kaitējumu vai zaudējumiem, kas radušies nolaidības dēḷ. Taču tās aizsargā arī citas tiesības, piemēram, reputāciju, personisko brīvību, īpašumtiesības, īpašuma esību un komercintereses. Galvenais tiesiskās aizsardzības līdzeklis, kas tiek lietots šajos gadijjumos, ir zaudējumu piedziņa, taču dažkārt tiek sūtīti izpildraksti, lai novērstu kaitējumu atkārtošanos. [13]

Delikts ir jāsaprot arī kā civiltiesiska saistība, kura ir izveidojusies saskaṇā ar likumu, no personas subjektīvo tiesību aizskāruma ārpus līgumiskām attiecībām.

Civilprocesa likuma 1. panta pirmajā dạ̦ā noteikts, ka katrai fiziskai un juridiskai personai ir tiesības uz savu aizskarto vai apstrīdēto civilo tiesību vai ar likumu aizsargāto interešu aizsardzību tiesā [2].

Taču Civillikumā ietverts arī jēdziens "neatḷauta darbība". Tādējādi ir secināms, ka neatḷauta ir katra darbība, kura rada tiesību aizskārumu, kā arī tad, ja to rada bezdarbība, savukārt neatḷautā darbība un bezdarbība tiek iedalīta:

- līguma saistību nepildīšana jeb līgumattiecību pārkāpums, piemēram, nokavējums;

- delikts jeb ārpuslīgumisks pārkāpums, kas var izpausties personiskos veselības, dzīvības, goda, cieñas, brīvības vai mantiskos aizskārumos.

Neatḷautas darbības pretstats ir atḷauta (tiesiska) darbība, kas, pirmām kārtām, ir katram subjektam piederošo tiesību izlietošana. Par neațlautu darbību vai bezdarbību ir paredzēta civiltiesiskā atbildība, kura izpaužas aizskārēja personas, kas izdarījusi neatl̦autu darbību vai piẹ̦āvusi neatḷautu bezdarbību, pienākumā atlīdzināt cietušajam ar to radušos zaudējumus. [9]

Savukārt runājot par zaudējumiem, jāatzīmē, ka to atlīdzināšana ir galvenais aizskāruma apmierinājuma līdzeklis, kura mērḳis ir novērst sekas un atjaunot iepriekšējo stāvokli, kāds bijis pirms tiesību pārkāpuma. Pēc sava rakstura zaudējumi ir mantas samazinājums vai bojājums, kā arī peḷnas samazinājums un papildu izdevumi.

Civiltiesiskajai atbildībai un tai sekojošai zaudējumu atlīdzināšanai ir četri priekšnoteikumi:

- kādas personas prettiesiska rīcība (darbība vai bezdarbība);

- šìs personas vaina;

- zaudējumu esamība un to konkrēts apmērs;

- cēloniskais sakars starp prettiesisko rīcību un zaudējumiem. [9] 
Pastāvot šeit uzskaitītajiem priekšnoteikumiem, ir pamats runāt par zaudējumu atlīdzināšanu civiltiesiskā kārtībā. Lai izprastu delikta mūsdienīgo aspektu, kurš tiek atspoguḷots normatīvajā regulējumā, jāizvērtē, ar ko delikts atškiriras un kuras tā pazīmes ir tādas pašas kā normatīvajā regulējumā esošiem citiem jēdzieniem.

Delikta un saistības pārkāpuma gadījumā zaudējumu atlīdzības priekšnoteikumi atšķiras. Tāpēc (ar retiem izṇēmumiem) katram gadỉjumam ir savs prasījuma pamats un sava tiesību norma. Latvijā zaudējumu atlīdzības prasījuma pamats delikta gadījumā ir Civillikuma 1635. pants, bet saistības pārkāpuma gadījumā - Civillikuma 1779. pants. [14] Tādējādi ir pamats padziḷināti izpētīt Civillikuma 1635. pantu, kurā ir noteikts, ka katrs tiesību aizskārums, tas ir, katra pati par sevi neaț̣auta darbība, kuras rezultātā nodarīts kaitējums (arī morālais kaitējums), dod tiesību cietušajam prasìt apmierinājumu no aizskārēja, ciktāl viṇu par šo darbību var vainot. [1] Šã panta struktūra ir kā saistītu jēdzienu virtene, kā no viena apstākḷa vai fakta izrietošu seku rezultāts, kurš savukārt veido shēmu, proti, - ar neațautu darbïbu tiek nodarīts kaitējums, kas cietušajam dod tiesības prasīt apmierinājumu, tas savukārt ir ierobežots, ciktāl aizskārēju par šo darbību var vainot. Šì shēma ir kā virtene, kuras katra elementa esamība ir neizbēgama. Var arī secināt, ka Civillikuma 1635. pantā ietverti stingri priekšnoteikumi, proti, kaitējuma esamība, kura viennozīmīgi ir cēloniskā sakarā ar neatḷauto darbību vai bezdarbību, un, protams, priekšnoteikums ir arī pati neaț̣autā darbība vai bezdarbība. Tādējādi ir nodalāmi trīs priekšnoteikumi, kuri veido panta skeletu.

Izpētot šā panta jēgu un piepildījumu, ir vērts pievērsties Civillikuma komentāros dotajam skaidrojumam, ka tiesību aizskāruma gadījumā ir tiesības prasìt apmierinājumu, ka aizskārējam ir jādod apmierinājums. Civiltiesību galvenais uzdevums ir nodrošināt mantisko attiecību ekvivalenci. Taču civiltiesỉbas aizsargā arī personiskos labumus, ko nevar aizstāt ar naudu, tāpēc ne vienmēr ir pareizi runāt par zaudējumu atlīdzību. Šā iemesla dēl vispārināti tiek lietots plašākais apzīmējums "dot apmierinājumu". Termins "apmierinājums" ir jālieto arī tajos gadījumos, kuros strīds radies par mantas atdošanu, piemēram, patapinājumā, vai tajos gadījumos, kad kreditors vēlas, lai parādnieks izpilda noteiktu darbību vai atturas no darbības. [12]

Runājot par vainu un tās noteikšanu, jāuzsver, ka Civillikumā ietvertas daudzas vainas formas, piemēram, neuzmanība, kura savukārt var būt gan rupja, gan viegla, kā arī l̦auns nolūks, kurš savukārt ir katrs tǐšs kaitējums. Tomēr vainas noskaidrošanai ir nepieciešams arī cēloniskais sakars, kura konstatēšana un pakāpe ir svarīga vainas smaguma noteikšanā. Situācijas mēdz būt dažādas, un cēloṇsakarības pakāpes noteikšana ir allaž aktuāla. Piemēram var aplūkot šādu situāciju: divu uzṇēmumu sadarbība notiek saskañā ar noslēgtiem līgumiem, taču viena puse "SIA A" nepilda savas saistības, bet otra puse "SIA B" vēršas tiesā ar prasību, taču procesa laikā "SIA B" kḷūst maksātnespējīga, jo parādās vēl arī citi saistību nepildītāji. Te rodas jautājums, cik lielā mērā "SIA A" ir vainojama pie tā, ka "SIA B" iestājas maksātnespēja, vai tā iestātos arī gadījumā, ja saistības tiktu pildītas? Visdrīzāk, ka jā, taču daḷejja vaina vai cēloniskais sakars starp saistību nepildī̌̌anu un maksātnespējas iestāšanos nav noliedzams. 
Salīdzinājumam var minēt arī Eiropas deliktu tiesību principus, kuros tiek skaidrots, vai un kādā pakāpē kaitējumu var attiecināt uz aizskārēju, proti, ka tas ir atkarīgs no vairākiem faktoriem, to skaitā no kaitējuma paredzamības, personas saprātīguma, darbības laika, jo īpaši n,emot vērā laika vai telpas tuvumu starp kaitīgo darbību un tās sekām vai kaitējuma apmēru attiecībā pret normālu šādas darbības rezultātu. [10]

Arī Civillikuma komentāros sniegts skaidrojums par vainu apskatāmā jautājuma aspektā, proti, lai prasītu apmierinājumu, ir jānoskaidro, vai un ciktāl aizskārēju var vainot par viña darbību vai bezdarbību. Tomēr tiek stingri norādīts, ka civiltiesībās vainas definīcija nevar būt tāda, kā to atzīst krimināltiesībās. Vaina ir saistīta ar personas psihisko attieksmi, bet tā nav pati psihiskā attieksme vai tikai psihiskā attieksme. Civiltiesisko attiecību subjekti, kā zināms, ir arī juridiskas personas. Runāt par šo personu psihisko attieksmi vispār nav logiiski, jo psihe var piemist tikai fiziskām personām. Turklāt l̦auna nolūka traktējums stipri atškiras no neuzmanības traktējuma, kas savukārt apgrūtina vienotas vainas definīcijas izstrādāšanu. [12]

No minētā var secināt, ka tieši nolūks un neuzmanība var veidot vainu, taču nedrīkst aizmirst, ka paša jēdziena "vaina" izpratne administratīvajās tiesībās, krimināltiesībās un civiltiesībās krasi atšḳiras.

Lai gūtu plašāku un dzị̣āku apskatāmā jautājuma izpratni, ir jāanalizē arī judikatūrā pastāvošie viedokḷi un nostājas. Latvija Republikas Augstākās tiesas tiesu prakses apkopojumā norādīts, ka morālais kaitējums ir personas ciešanas, sāpes un pārdzīvojumi, ko nav iespējams tieši novērtēt. Pārciestā sekas nav iespējams aizstāt ar naudu, taču, sniedzot cietušajai personai atbilstīgu atlīdzinājumu naudas izteiksmē, ir iespējams sniegt viṇai zināmu gandarījumu un tādējādi mazināt ciešanas un sāpes. Tā kā morālais kaitējums ir aizskāruma negatĩvās sekas, tiesai pēc prettiesiskas rīcības fakta visupirms ir jākonstatē morālā kaitējuma esamība un tikai pēc tam jāvērtē atlīdzības apmērs. [11]

Jāṇem vērā, ka pēc būtības zaudējumu atlīdzība Latvijas tiesībās primāri tiek regulēta ar Latvijas Republikas Satversmes 92. panta trešo teikumu, proti, nepamatota tiesību aizskāruma gadījumā ikvienam ir tiesības uz atbilstīgu atlīdzinājumu [3]. Taču nedrīkst aizmirst, ka ir jānošḳir atlīdzības prasības pret privātpersonām civilprocesa un kriminālprocesa ietvaros un atlīdzības prasības pret valsti, kuras savukārt tiek regulētas administratīvā procesa ietvaros. Nav iespējams nošḳirt pašu tiesību aizskārumu un atlīdzinājumu, jo nav noteikti atlīdzības standarti, un rodas jautājums par atlīdzības atbilstību. Jāatzīst, ka atbilstīga atlīdzinājuma problemātika bieži tiek analizēta judikatūrā, un daḷeji jāpiekrīt Latvijas Republikas Augstākās tiesas nostājai, ka ir noškirama virkne principu, kas ir jāievēro atlīdzinājuma noteikšanā. Lai atlīdzinājums būtu atbilstīgs Latvijas Republikas Satversmes 92. panta izpratnē, tam ir jābūt efektīvam tiesiskās aizsardzības līdzeklim [5]. Jēdziens "atbilstīgs atlīdzinājums" nozìmē, ka atlīdzinājumam ir jābūt taisnīgam. Atlīdzinājumam ir jāsniedz gandarījums personai, kuras tiesības ir tikušas aizskartas [7]. Tādējādi atlīdzinājums demokrātiskā un tiesiskā valstī nedrīkst būt nesamērīgi mazs [6]. Tomēr apskatot "atbilstīga atlīdzinājuma" jēdzienu un Latvijas Republikas Satversmes 92. panta trešo teikumu, var secināt, ka atbilstīga atlīdzinājuma izpratne parasti tiek 
skatīta finansiālā aspektā, t. i., cik liela naudas summa ir atzīstama par pietiekošu apmierinājumu. Ir vērts pievērst uzmanību tam, ka jēdzienam "atbilstīgs atlīdzinājums" nedrīkst pieškirt tikai mantisku raksturu, jo sasniegt taisnīgumu un sniegt gandarijumu jeb apmierinājumu personai, kuras tiesības ir aizskartas, var arī nemateriālā veidā, piemēram, publiska atvainošanās var sniegt apmierinājumu.

Tiesību aizskārums un atlīdzinājums nevar tikt uzskatīts par iespēju piepelnīties, un to nedrīkst noteikt, vērtēšanā izmantojot kādu matemātisku formulu. Ja romiešu tiesībās bija pien,emts konkrēts mantisks atlīdzinājums par konkrētu tiesību pārkāpumu un šāda pieeja neradīja mulsumu, tad mūsdienās tiesību normas nevar tikt matemātiski pamatotas. Līdzịga nostāja ir pausta vairākos Eiropas Cilvēktiesību tiesas nolēmumos, kuros tiek minēts, ka taisnīga atlīdzinājuma noteikšanā tiesa ir nošḳīrusi tos gadījumus, kuros iesniedzējs guvis fizisku vai psiholoǵisku traumu, mokas, nemieru, neapmierinātību, piedzīvojis sāpes un ciešanas, netaisnības vai pazemojuma sajūtu, ilgstošu neskaidrību, dzīves izpostî̌̌anu vai arī patiesu iespēju zudumu, no gadījumiem, kuros iesniedzējam nodarīts kaitējums mazākā mērogā, un tādēḷ publisks atzinums dalībvalstij saistošā spriedumā pats par sevi tiek uzskatìts par spēcīgu kompensācijas veidu [4]. Proti, jau pati par sevi apstākḷa, ar kuru tikušas aizskartas tiesības, atzīšana par tiesību normām neatbilstošu vai spēkā neesošu sniedz pietiekošu apmierinājumu, dodot pamatu arī citiem sabiedrības locekḷiem justies pasargātākiem no tiesību pārkāpumiem, nekā bija iepriekš. Taču gadījumos, kuros tiesību pārkāpuma apmierinājums tiek sniegts naudas izteiksmē, netiek skatìta situācija plašāk, vērtējot tiesību aizskarošo procesu atbilstību un iespēju tos labot, un nepiel̦aut turpmāk. Rodas situācija, ka nolēmums l̦auj skaidri redzēt robežu, kas vēlmi gūt kādu materiālu labumu un gūt apmierinājumu par tiesību pārkāpumu noškịir no vēlmes saņemt atziņu par notikušo un apliecinājumu, ka tiesības tikušas aizskartas. Materiālā apmierinājuma guvums nevar būt vienīgā sabiedrības vērtību skala.

“Tiesiskās aizsardzības efektivitāte" un "atbilstīgs atlīdzinājums", kā arī daudzi citi jēdzieni, kuri pēc būtības tiek haotiski minēti, piemēram, judikatūrā, bieži vien nav jēdzieni, kuri pārklājās. Tiesības var būt efektīvi aizsargātas, bet rodas jautājums, vai to aizsardzība ir taisnīga, samērīga un visbeidzot - atbilstīga? Atbildot uz šiem jautājumiem, parādās viens no sarežgî̀tākajiem apskatāmā temata aspektiem, proti, kā pierādīt tiesību aizskāruma apmēru un noteikt ekvivalentu atlīdzinājumu, kā izvēlēties atlīdzinājuma līdzekli un veidu, kurš sniegs paredzamo apmierinājumu? Šie jautājumi judikatūrā bieži vien tiek atstāti bez atbildes. Kaut arī juridiskajā literatūrā ir minēts, ka izšḳirošs ir tieši atlīdzinājuma līdzeklis, kurš nodrošina efektīvu tiesisko aizsardzỉbu konkrētajam tiesību aizskārumam, tomēr atlīdzinājums biežāk tiek saprasts kā novērtējums naudas izteiksmē. Taču neapšaubāmi atšķirīga un pat nesalīdzināma ir katras personas izpratne par naudas apmēru, kurš rada apmierinājumu, jo tas ir samērīgs ar katras personas dzīves līmeni, prasībām un izpratni. Šie aspekti ir paḳ̣auti arī vecumam un izglìīibas līmenim - jauns cilvēks savas karjeras sākumā ir mazāk prasīgs, persona brieduma gados ar labiem ienākumiem citādāk vērtē savu tiesību ierobežojumu un visbeidzot personai cienījamā vecumā ir sava, ḷoti atšḳirīga kritēriju skala un prasības. 


\section{Secinājumi}

Izpratne par atbilstīgu atlīdzinājumu kā tikai finansiāli piepildītu jēdzienu ir pārāk šaura un liek domāt par analogiju ar prētoriskām tiesībām, kurās par konkrētu aizskārumu tika paredzēts atlīdzinājums ar likumā noteiktu naudas summu.

Atš̌kirīibā no Senās Romas mūsdienu sabiedrībā nav iespējama doma, ka katra aizskāruma scenārijs ir iepriekš aprēḳināts naudas izteiksmē. Lai arī cik produktīvi būtu šāda veida strīdu risināšanas modelii, tomēr tie izslēgtu iespēju individuāli vērtēt katru gadïjumu. Taču nevar arī neminēt to, ka katra gadỉjuma atšķirīga vērtēšana atstāj vietu nevienlīdzībai. Proti, ja persona zināšanu trūkuma dēl nav informēta par iespējām, tā nevar tās izmantot pilnā apmērā vai pat daḷejii, savukārt cita persona spēj gan finansiāli, gan arī zināšanu līmenī izkonkurēt citus, tādējādi gūstot lielākus panākumus savu tiesību aizsardzībā.

\section{Insight into Tort Law}

\section{Abstract}

The aim of the article is to provide an insight into the Tort Law, which will reveal historical and contemporary fulfillment of the notion itself, as well as to present an insight into a broader issue of the problem of protection of unjustified infringement of the rights of a person and their solutions.

Keywords: Tort Law, satisfaction, infringement of law.

\section{Avoti un literatūra}

\section{Tiesību akti}

1. Civillikums: Latvijas Republikas likums: pieṇemts 28.01.1937. un stājās spēkā 01.09.1992. Valdỉbas Vēstnesis. 41, 20.02.1937. Iegūts no: https://likumi.lv/doc.php?id=225418 [sk. 01.07.2019.].

2. Civilprocesa likums: Latvijas Republikas likums: pieṇemts 14.10.1998. un stājās spēkā 01.03.1999. Latvijas Vēstnesis. 326/330(1387/1391), 03.11.1998. Iegūts no: https://likumi.lv/doc.php?id=50500 [sk. 01.07.2019.].

3. Latvijas Republikas Satversme: Latvijas valsts likums: pieṇemta 15.02.1922. un stājās spēkā 07.11.1922. Latvijas Vēstnesis. 43, 01.07.1993. Iegūts no: https://likumi.lv/doc.php?id=57980 [sk. 01.07.2019.].

\section{Tiesu prakse}

4. European Court of Human Rights Case of Varnava and Others v. Turkey. 18 September 2009. Strasbourg (Applications nos. 16064/90, 16065/90, 16066/90, 16068/90, 16069/90, 16070/90, 16071/90, 16072/90 and 16073/90). Iegūts no: https://hudoc.echr.coe.int/eng\# ‘"appno":["16064. /90"],"itemid":[“001-94162"]\} [sk.01.07.2019.]. 
5. Latvijas Republikas Augstākās tiesas Senāta Administratīvo lietu departamenta 2007. gada 1. marta spriedums lietā Nr. SKA-54/2007, 8. punkts.

6. Latvijas Republikas Augstākās tiesas Senāta Administratīvo lietu departamenta 2010. gada 16. februāra spriedums lietā Nr. SKA-104/2010, 18. punkts.

7. Latvijas Republikas Augstākās tiesas Senāta Administratīvo lietu departamenta 2011. gada 18. februāra spriedums lietā Nr. SKA-161/2011, 16. punkts.

\section{Literatūra}

8. Birziṇa, L. 2006. Romiešu tiesības. 2. izd. Rìga.

9. Džugleja, T. 2011.Tiesību pamati: Mācību lìdzeklis. Rīga: Rīgas Tirdzniecības tehnikums.

10. European Group on Tort Law: Principles of European Tort Law. Universitat de Girona. 2005. Iegūts no: http://civil.udg.edu/php/biblioteca/items/283/PETL.pdf [sk.01.07.2019.].

11. Latvijas Republikas Augstākā tiesa: Morālā kaitējuma atlīdzināšana civillietās: Tiesu prakses apkopojums. Rīga, 2014.

12. Latvijas Republikas Civillikuma komentāri: 4. d.: Saistību tiesības (1401.-2400. p.). Zin. red. K. Torgāns. Rīga: Mans īpašums, 1998.

13. Oxford Dictionary of Law. Oxford Reference. 2009. Iegūts no: doi:

14. 10.1093/acref/9780199551248.001.0001 [sk.01.07.2019.].

15. Strazdiṇš, G̣. Vispārējais zaudējumu atlīdzības prasījuma pamats delikta un saistības pārkāpuma gadijjumā. Jurista Vārds. 6(1012), 06.02.2018. 
https://doi.org/10.25143/socr.13.2019.1.104-109

\title{
Personas datu aizsardzības mērḳis un tiesiskā regulējuma vēsturiskā attīstība
}

\author{
Mg. iur. Agnese Reine-Vïtina \\ Rìgas Stradiṇa universitāte, Juridiskā fakultāte, Latvija \\ agnese.reine-vitina@rsu.lv
}

\section{Kopsavilkums}

Mūsdienās tiesības uz privāto dzīvi nepieciešamas ikvienā demokrātiskā sabiedrībā, un šo tiesību iekḷaušana konstitūcijā juridiski garantē fiziskas personas rīcības brīvību un vienlaikus arī citu - valsts pamatlikumā noteikto - cilvēka tiesību īstenošanu [5]. Personas datu aizsardzības institūts tika izveidots, izpratnes par tiesību uz personas privātās dzīves neaizskaramību saturu paplašinot 20. gadsimta 70. gados, kad vairāku Eiropas valstu valdības uzsāka informācijas apstrādes projektus, piemēram, tautas skaitīšanu u. c.

Informācijas tehnologiju attīstība ḷāva arvien vairāk informācijas par personām glabāt un apstrādāt elektroniski. Viena no tiesību problēmām bija informācijas vākšana par fizisku personu un tiesību uz privātās dzīves neaizskaramību ievērošana. Lai nodrošinātu privātās dzīves aizsardzību, atsevišḳas Eiropas valstis pēc savas iniciatīvas pieñēma likumus par datu aizsardzību. Pirmie likumi par personas datu aizsardzību Eiropā tika pieñemti Vācijas Federatīvajā Republikā, tad Zviedrijā (1973), Norvēǵijā (1978) un citur $[8,10]$. Ne visas valstis pieṇēma likumus par datu aizsardzību vienlaikus, tāpēc Eiropas Padome nolēma izstrādāt konvenciju, lai unificētu datu aizsardzības noteikumus un principus.

Atslēgvārdi: dati, fiziska persona, datu aizsardzība, cilvēktiesības, vēsturiskā attīstība.

\section{levads}

Mūsdienu tehnologiju attīstība un globalizācija ir mainījusi personas datu aizsardzības aktualitāti, izvirzot to par prioritāti. Lìdz ar Vispārīgās datu aizsardzības regulas stāšanos spēkā tika radīts jauns, vienots tiesiskais regulējums visā Eiropas Savienībā.

Raksta mērķis ir analizēt personas datu apstrādes tiesiskā regulējuma vēsturisko attīstību, lai varētu izprast personas datu apstrādes mērḳus un tiesiskā regulējuma 
piemērošanas īpatnības. Lai sasniegtu izvirzīto mērḳi, izmantotas tiesību normu interpretācijas metodes - vēsturiskā, gramatiskā, sistēmiskā un teleologiskā, kā arī vispārzinātniskās pētniecības metodes - analītiskā, aprakstošā un vēsturiskā metode.

\section{Personas datu tiesiskā regulējuma vēstures galvenie pieturpunkti}

Eiropas Padomes ieguldījums privātās dzīves aizsardzības tiesību nostiprināšanā ir īpaša Eiropas Padomes 1981. gada 28. janvāra Konvencija Nr. 108 par personu aizsardzību attiecībā uz personas datu automātisko apstrādi (turpmāk tekstā - Konvencija). Konvencijas preambulā ir noteikts, ka vēlams paplašināt katras personas tiesību un pamatbrīīibu aizsardzību, it īpaši tiesību uz privātās dzīves neaizskaramību, ņemot vērā automātiski apstrādātu personas datu arvien pieaugošo plūsmu pāri robežām, un Konvencijas dalïbvalstīm tika izvirzìtas konkrētas prasības attiecībā uz personas datu tiesisko aizsardzību [8, 11]. Konvencijas tvērums attiecas uz Eiropas Padomes dalībvalstīm, kuras parakstijjušas un ratificējušas šo Konvenciju, kā arī uz četrām valstīm, kuras nav Eiropas Padomes dalībvalstis, taču, pamatojoties uz uzaicinājumu, parakstijja un ratificēja Konvenciju (Maurīcija, Senegāla, Tunisija un Urugvaja) [9].

Vēl pagājušā gadsimta 90. gados visās Eiropas Savienības (turpmāk tekstā - ES) dalībvalstīs nebija speciālu likumu par datu aizsardzību, bet esošie likumi paredzēja diezgan atšķirīgus noteikumus. Viena no lielākajām problēmām bija tā, ka ES dalībvalstu likumos par datu aizsardzibu tika noteikts aizliegums nodot personas datus uz citu valsti, ja tajā nav atbilstošas aizsardzības $[8,11]$.

Māstrihtas līguma F 2. pantā tika noteikts, ka ES respektēs pamattiesības, kas garantētas Cilvēktiesību konvencijā, dalībvalstu konstitucionālajās tradīcijās un Savienības vispārīgajos principos. Pamatojoties uz to, kā arī nolūkā ievērot vienotā tirgus principu 1995. gada 24. oktobrī ES tika pienemta Eiropas Parlamenta un Eiropas Padomes Direktīva 95/46/EK "Par personas aizsardzību attiecībā uz personas datu apstrādi un to brīvu apriti” [2]. Šajā Direktīvā paredzēts, ka ES dalībvalstīm līdz 1998. gada 24. oktobrim jāpiennem atbilstoši normatīvie akti, ar kuriem tiek reglamentēta personas datu apstrādes kārtỉba $[8,11]$.

Eiropas Savienība 2000. gada 7. decembrī pieṇēma Eiropas Savienības Pamattiesību hartu. Hartas 8. pantā paredzēts, ka ìpaši tiek izdalītas personas tiesības uz datu aizsardzību. Citos starptautiskajos dokumentos un Satversmē tās ietvertas privātās dzīves jēdzienā un tādēl netiek atsevišḳi izdalìtas:

- ikvienai personai ir tiesības uz savu personas datu aizsardzỉbu;

- personas dati jāapstrādā godprātīgi, noteiktiem mērḳiem un ar attiecīgās personas piekrišanu vai ar citu likumigu pamatojumu, kas paredzēts tiesību aktos;

- ikvienam ir pieejas tiesības datiem, kas par viṇu savākti, un tiesības ieviest labojumus šajos datos;

- atbilstību šiem noteikumiem kontrolē neatkarīga iestāde. [4] 
Tāpat kā Satversmes 96. pantā, arī Cilvēka tiesību un pamatbrīiību aizsardzības konvencijas 8. pantā [1] ir noteiktas personas tiesības uz privātās dzīves neaizskaramību. Ar privātās dzīves neaizskaramību tiek saprastas arī personas tiesības uz datu aizsardzību [5].

Tehnologiju straujā attīstība un pieaugošā tiesu prakse, skaidri norādỉja uz nepieciešamību pieñemt jaunu starptautisku tiesisko regulējumu attiecībā uz personas datu apstrādi. Iepriekšējais regulējums bija Eiropas Parlamenta un Padomes Direktīva 95/46/EK (1995. gada 24. oktobris) par personas aizsardzību attiecībā uz personas datu apstrādi un šādu datu brīvu apriti (turpmāk tekstā - Direktīva). Nemot vērā, ka Direktīva tika pieñemta 1995. gadā, skaidri saprotams, ka tās tvērums neatbilst mūsdienu datu apstrādes procesiem un nenodrošina personas datu nepieciešamo aizsardzību.

2012. gada 25. janvārī Eiropas Komisija ierosināja visaptverošu 1995. gada ES datu aizsardzības reformu, lai nostiprinātu tiesības uz privātumu tiešsaistē un stimulētu Eiropas digitālo ekonomiku. Jauna ES datu aizsardzības regulējuma ieviešanas mērkis bija panākt vienveidīgu datu aizsardzības normatīvā regulējuma attīstību gan ES, gan nacionālajā līmenī.

Jaunais regulējums, tehnologiskais progress un globalizācija ir dziḷi mainījuši veidu, kā tiek vākti personas dati, kā notiek piekḷuve tiem un kā dati tiek izmantoti, turklāt 27 ES dalībvalstis 1995. gada noteikumus ir îstenojušas atšḳirīgi, tāpēc arī to izpilde ir notikusi dažādi. Vienotam tiesību aktam vajadzēja novērst pastāvošo sadrumstalotību. "Pirms 17 gadiem mazāk nekā $1 \%$ eiropiešu lietoja internetu. Mūsdienās ik sekundi notiek milzīga personas datu apjoma nosūtišana un apmaiṇa starp kontinentiem un visā pasaulē," sacīja Viviāna Redinga, ES tieslietu komisāre un Komisijas priekšsēdētāja vietniece [10].

2012. gada 7. martā Eiropas datu aizsardzības uzraudzītājs (turpmāk tekstā - EDAU) sniedza atzinumu par datu aizsardzības reformas paketi, kurā ietverti detalizēti komentāri par priekšlikumiem. EDAU atzinumā pauda šādu viedokli: "EDAU atzinīgi vērtē ierosināto regulu, jo tā ir liels solis uz priekšu Eiropas datu aizsardzības jomā. Ar ierosinātajiem noteikumiem tiks nostiprinātas fizisku personu tiesības un paredzēta lielāka pārziṇu atbildība par veidu, kādā tie rīkojas ar personas datiem. Turklāt ierosinātajā regulā faktiski tiek paplašinātas valstu uzraudzības iestāžu (atseviški un kopā) pilnvaras un uzdevumi. EDAU pauž īpašu gandarījumu par to, ka ierosinātais vispārīgu datu aizsardzības noteikumu piemērošanas instruments ir regula. Ierosinātā regula būtu tieši piemērojama dalībvalstīs un novērstu daudzus sarežǵìjumus un neatbilstības, ko izraisītu dažādie îstenošanas tiesību akti, kas patlaban ir spēkā dalībvalstīs. EDAU uzsver, ka, lai gan tiesībaizsardzības jomā ir vajadzīgi īpaši noteikumi, ikviena atkāpe no vispārējiem datu aizsardzības noteikumiem ir pietiekami jāpamato, nodrošinot pienācīgu līdzsvaru starp sabiedriskajām interesēm tiesībaizsardzības jomā un pilsoṇu pamattiesībām.” [11]

Straujā tehnologiju attīstība un globalizācija ir radījusi jaunas problēmas personas datu aizsardzībā. Personas datu vākšanas un apmaiṇas apjoms ir būtiski pieaudzis. Tehnologiijas lauj gan privātām uzṇēmējsabiedrībām, gan publiskām iestādēm vēl nepieredzētā apjomā savas darbības mērḳiem izmantot personas datus. Fiziskas personas 
aizvien biežāk piel̦auj personiska rakstura informācijas publisku un globālu pieejamību. Tehnologiijas ir pārveidojušas gan ekonomiku, gan sociālo dzīvi, un tām arī turpmāk būtu jāuzlabo personas datu brīva aprite Eiropas Savienībā un nosūtišana uz trešajām valstīm un starptautiskām organizācijām, vienlaikus nodrošinot personas datu augsta līmeņa aizsardzību [3]. Nekontrolētas datu apstrādes sekas var būt datu subjektu tiesību uz privāto dzìvi aizskārums, kas savukārt var novest pie liela prasību skaita pieauguma tiesās attiecībā uz personas datu aizsardzības pārkāpumiem.

Tehnologiskā attīstība un cilvēku paradumu maiṇa skaidri norādỉja uz jauna regulējuma aktualitāti un nepieciešamību. Tā tvērumam vajadzēja atbilst datu apstrādes mūsdienu principiem, paradumiem un sistēmām, kā arī nodrošināt apstrādājamo / uzglabājamo datu drošỉbu.

Direktīvas mērki un principi joprojām ir spēkā, taču tā nespēja novērst datu aizsardzības isstenošanas sadrumstalotỉbu ES, juridisko nenoteiktîbu un sabiedrībā plaši izplatîtu uzskatu, ka pastāv ievērojams fizisku personu datu aizsardzības risks, jo īpaši tiešsaistes aktivitātēs [3, preambulas 9. punkts]. Direktīva pilnībā nesasniedza mērḳi tieši juridiskās formas dēḷ. Direktīvā tika norādīti tikai ES dalībvalstu kopīgie mērḳi, katrai dalībvalstij nacionālā līmenī sniedzot iespēju mērḳus iestrādāt, tos korigêejot un pielāgojot atbilstoši dalībvalsts vajadzībām. Šāda plaša un brīva Direktīvas interpretācijas iespēja veicināja to, ka ES dalïbvalstīs neradās vienots datu aizsardzības regulējums.

2016. gada 27. aprīli tika pien,emta Eiropas Parlamenta un Padomes Regula (ES) 2016/679 par fizisko personu aizsardzību attiecībā uz personas datu apstrādi un šādu datu brīvu apriti un ar ko atcel Direktīvu 95/46/EK (Vispārīgā datu aizsardzības regula), turpmāk tekstā - Datu aizsardzības regula. Pieṇemot jauno tiesisko regulējumu tieši regulas formā, tika nodrošināta vienota izpratne un vienots tiesiskais regulējums visās ES dalībvalstīs. Pretstatā Direktīvai Datu aizsardzības regula ir juridiski saistoša un tieši piemērojama visās ES dalībvalstīs, un tas nozīmē, ka Datu aizsardzības regulas nosacījumi nav interpretējami un iestrādājami dalībvalstu nacionālajos tiesību aktos, veicot savas korekcijas. Dalībvalstis drīkst iestrādāt Datu aizsardzības regulas prasības arī nacionālajos tiesību aktos, tikai tiešā veidā pārnesot regulas prasības vai tās precizējot attiecībā uz nacionālo piemērošanu.

Datu aizsardzības regulas preambulas 4. punktā ir teikts, ka personas datu apstrāde būtu jāveido tā, lai tā kalpotu cilvēkam. Tiesības uz personas datu aizsardzību nav absolūta prerogatīva, tās ir jānnem vērā saistībā ar to funkciju sabiedrībā un jālīdzsvaro ar citām pamattiesībām saskaṇā ar proporcionalitātes principu. Šajā regulā ir ievērotas visas pamattiesības, brīvības un principi, kas atzīti hartā un ietverti līgumos, jo īpaši privātās un gimenes dzìves, mājokḷa un sazinnas neaizskaramība, personas datu aizsardzỉba, domu, pārliecības un ticības brīvība, vārda un informācijas brīvība, darījumdarbības brīvība, tiesības uz efektīvu tiesību aizsardzību un taisnīgu tiesu un kultūru, kā arī reliǵiju un valodu daudzveidíba [3].

Datu aizsardzỉbas regulas pieņemšanai ir liela nozīme, un tā iesāk būtisku attīstības posmu personas datu aizsardzības tiesiskajā regulējumā. Līdz ar tās ieviešanu, personas 
datu aizsardzība ir kḷuvusi par vienu no prioritātēm visiem personas datu apstrādātājiem un uzglabātājiem.

\section{Secinājumi}

Personas datu aizsardzība un tās tiesiskais regulējums ir attīstījies kopš 20. gadsimta 70. gadiem, kad aizvien biežāk informācija tika glabāta elektroniskā veidā. Personas datu aizsardzības tiesiskais regulējums Eiropā tika ieviests pakāpeniski, tādējādi nebija vienotas izpratnes gan par šāda regulējuma nepieciešamību, gan par datu apstrādes principiem. Vēsturiskās attīstības gaitā vairākkārt tika izstrādāti starptautiski tiesību akti, lai nodrošinātu vienotu regulējumu personas datu aizsardzībai, taču šie regulējumi nesasniedza mērḳi un nespēja novērst sadrumstalotību attiecībā uz datu apstrādes principiem. Analizējot datu apstrādes tiesiskā regulējuma attīstības gaitu, secināms, ka ieviestā Datu aizsardzības regula pēc savas juridiskās formas un izstrādātajiem noteikumiem nodrošina vienotu pieeju personas datu apstrādes principiem un to nodrošināšanai.

\section{Objective of Protection of Personal Data and Historical Development of Legal Framework}

\section{Abstract}

Nowadays, the right to privacy is indispensable in every democratic society and inclusion of such rights in the constitution, guarantees legally freedom of action of a natural person and, simultaneously, implementation of other human rights established in the fundamental law of the state. The institute of personal data protection was established by expanding the understanding of the content of the right to privacy in the 70's of the $19^{\text {th }}$ century, when the government of several European countries initiated information processing projects, such as population census etc. For the development of information technology, more and more information on persons was kept and processed in electronic form. One of the legal problems was gathering of information on natural persons and the right to privacy. In order to ensure the protection of privacy, separate European countries, on their own initiative, established a law on data protection. The first laws on the protection of personal data in Europe were established in the Federal Republic of Germany, then in Sweden (1973), Norway (1978) and elsewhere. Not all countries adopted laws on data protection at the same time, so the Council of Europe decided to elaborate a convention to unify data protection rules and principles.

Keywords: data, natural person, data protection, human rights, historical development. 
Agnese Reine-Vìtina. Personas datu aizsardzības mērḳis un tiesiskā regulējuma vēsturiskā attīstība

\section{Avoti un literatūra}

\section{Tiesību akti}

1. Cilvēka tiesību un pamatbrīvību aizsardzības konvencija: starptautisks dokuments: pieṇemta 04.11.1950. un stājās spēkā 27.06.1997. Latvijas Vēstnesis. 143/144(858/859), 13.06.1997.

2. Eiropas Padomes 24.10.1995. Direktīva 95/46/EK par personas aizsardzību attiecībā uz personas datu apstrādi un to brīvu apriti. Eiropas Savienības Oficiālais Vēstnesis. L281/31, 23.11.1995.

3. Eiropas Parlamenta un Padomes Regula (ES) Nr. 2016/679 (27.04.2016.) par fizisko personu aizsardzību attiecībā uz personas datu apstrādi un šādu datu brīvu apriti un ar ko atcel Direktīvu 95/46/EK (Vispārīgā datu aizsardzības regula): starptautisks dokuments. Eiropas Savienības Oficiālais Vēstnesis. L 119/1, 04.05.2016.

4. Eiropas Savienības Pamattiesību harta 2012/C 326/02: starptautisks dokuments. Eiropas Savienības Oficiālais Vēstnesis. C326/391, 26.10.2012.

5. Latvijas Republikas Satversme: Latvijas valsts likums: pieṇemta 05.02.1922. un stājās spēkā 07.11.1922. Latvijas Vēstnesis. 43, 01.07.1993.

\section{Tiesu prakse}

6. Satversmes tiesas 12.05.2016. spriedums lietā Nr. 2015-14-0103 "Par DNS nacionālās datubāzes izveidošanas un izmantošanas likuma 1. panta 2. un 6. punkta, 4. panta, 10. panta, 18. panta pirmās daḷas, kā arī Ministru kabineta 2005. gada 23. augusta noteikumu Nr. 620 “DNS nacionālajā datubāzē iekḷaujamo ziṇu sniegšanas, kā arī biologiskā materiāla un biolog̣iskās izcelsmes pēdu izṇemšanas kārtība" 2. un 13. punkta tiktāl, ciktāl tie attiecas uz aizdomās turētajām personām, atbilstību Latvijas Republikas Satversmes 96. pantam”. Latvijas Vèstnesis. 92(5664), 13.05.2016.

\section{Literatūra}

7. Morgan, R., Boardman, R. 2012. Data protection strategy. Implementing data protection compliance. London: Sweet\&Maxwell Limited.

8. Ruksers, M. 2008. Fizisko personu datu aizsardzības likuma komentāri. Rīga: SIA "E-sabiedrības risinājumi”.

\section{Interneta resursi}

9. Chart of signatures and ratifications of Treaty 108. Council of Europe. Iegūts no: https://www. coe.int/en/web/conventions/full-list/-/conventions/treaty/108/signatures?p_auth=nQZzeuBp [sk. 01.05.2019.].

10. Eiropas Komisijas paziņojums presei. Komisija ierosina visaptverošu datu aizsardzības noteikumu reformu, lai palielinātu lietotāju iespējas kontrolēt savus datus un samazinātu izmaksas uzṇēmumiem. European Commission. Iegūts no: https:/europa.eu/rapid/press-release_IP-12-46_ lv.htm [sk. 03.08.2019.].

11. Opinion of the European Data Protection Supervisor on the data protection reform package. European Data Protection Supervisor. Iegūts no: https:/edps.europa.eu/sites/edp/files/publication/12-03-07_edps_reform_package_en.pdf [sk. 22.07.2019.]. 


\title{
Autoru alfabētiskais rādītājs / Alphabetic List of Authors
}

\author{
Alfejeva, Jeḷena 7, 9, 63 \\ Bērziṇa-Ruḳere, Ilze 7, 9, 22 \\ Jilkine, Vladimir 7, 9, 42 \\ Kipāne, Aldona 7, 9, 50 \\ Matvejevs, Aleksandrs 7, 9, 11 \\ Reine-Vītina, Agnese 8, 10, 104 \\ Segale, Dana 8, 10, 96 \\ Snipe, Arta 8, 10, 76 \\ Trẹ̦s, Ëriks 7, 9, 30 \\ Vilks, Andrejs 7, 9, 50
}


Pielikums

\section{RSU Juridiskās fakultātes akadēmiskā personāla sagatavotās un izdotās monogrāfijas (2009-2019)}

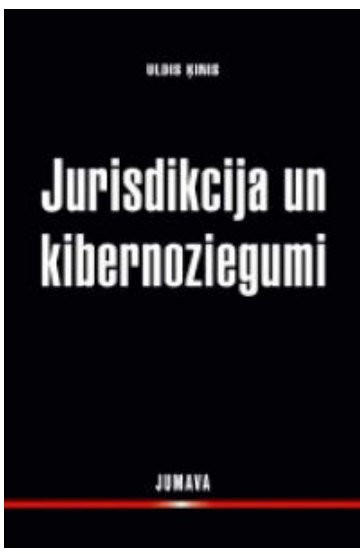

Kinis, U. (2013). Jurisdikcija un kibernoziegumi.

Jumava. 375 lpp.

RSU asociētais profesors Uldis Ķinis, būdams Eiropas Padomes Kibernoziegumu ekspertu komitejas eksperts, pievērš juristu un informācijas tehnologiju speciālistu uzmanību kibertelpai un kibernoziegumam, kas ir 21. gadsimtā radīts informācijas tehnologiju fenomens. Tam raksturīga noziedzīgu nodarījumu veikšana no jebkuras zemeslodes vietas, kur iespējams piekḷūt globālajam tīmeklim. Būtiski, ka, izmantojot kibertelpu, kaitīgo seku iestāšanās vieta bieži vien nesakrīt ar vainojamās personas domicilu. Šis apstāklis rada kolīziju starp tradicionālo teritoriālo jurisdikciju, kuras pamats ir teritorija un valsts piederīgo lojalitāte valsts likumiem, un kibertelpas globālo raksturu. Saistībā ar kibernoziegumiem grāmatā analizētas modernās krimināljurisdikcijas teorijas, juridisko konfliktu cēloṇi un to risināšanas mehānismi ne tikai Latvijā, bet arī globālajā vidē.

Profesors kopš 2000. gada piedalās Latvijas normatīvo aktu un tiesībpolitikas dokumentu izstrādāšanā, kas saistīti ar kibernoziegumu novēršanu, informācijas sistēmu drošību, bērnu tiesību aizsardzību internetā u. c. ar šo vidi saistītiem jautājumiem.

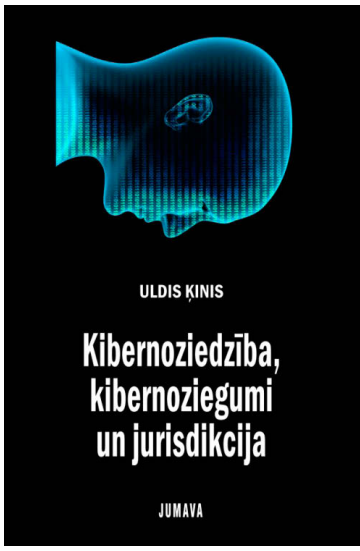

Kinis, U. (2015). Kibernoziedzība, kibernoziegumi un jurisdikcija. Jumava. $520 \mathrm{lpp}$.

Autors, juridisko zinātnu doktors un Rīgas Stradina universitātes asociētais profesors U. Ķinis, pievēršas kibernoziedzības attīstības tendencēm. Izdevumā aplūkoti kibernoziedzības jautājumi un tās veidi, kā arī analizēti Krimināllikumā ietvertie kibernoziegumi un noziedzīgi nodarījumi automatizētu datu apstrādes sistēmās. Turklāt autors no juridiskā viedokḷa aplūko Latvijā labi zināmos Denisa Čalovska un Neo gadijumus.

Uldim Ķinim ir plaša juridiskā darba pieredze - viņš ir bijis Eiropas Padomes Kibernoziegumu ekspertu komitejas eksperts un ES Likuma misijas Gruzijā vecākais eksperts tieslietu jautājumos. 2006. gada decembrī, Saeimas apstiprināts, viṇš kḷuva par Satversmes tiesas viceprezidentu, bet no 2008. līdz 2011. gada maijam bija ANO Starptautiskā bijušās Dienvidslāvijas kara noziegumu tribunāla ad litem tiesnesis. Kā minēts izdevēja sniegtajā grāmatas anotācijā, tad "grāmata ir domāta plašam lasītāju lokam visiem, kas interesējas par kibernoziedzību, kibernoziegumiem un ar tiem saistītām problēmām. Tomēr autora galvenais mērḳis ir sniegt nepieciešamās zināšanas tiesībaizsardzības speciālistiem, prokuroriem, tiesnešiem un advokātiem jautājumos, kas saistīti ar pierādījumu juridisko nostiprināšanu". 
Pielikums. RSU Juridiskās fakultātes akadēmiskā personāla sagatavotās un izdotās monogrāfijas (2009-2019)
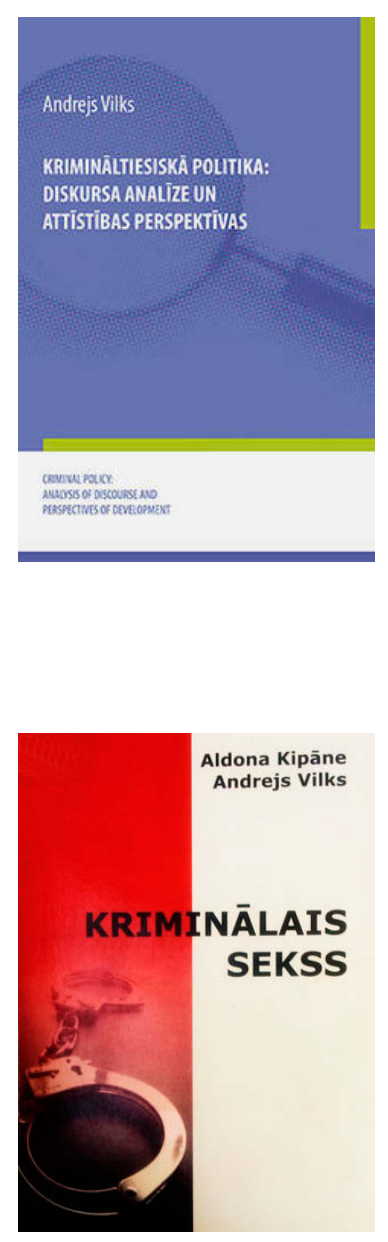

Vilks, A. (2013). Krimināltiesiskā politika: diskursa analīze un attīstības perspektīvas. SIA "Drukātava”. 266 lpp.

Norvēgu kriminologs Nils Kristi ir atzinis, ka jābaidās nevis no noziedzības, bet gan no sekām, to apkarojot. Krimināltiesiskā politika ir ne tikai instruments cilvēka brīvību un tiesību nodrošināšanai, bet arī ierobežošanai. Latvijas iedzīvotājiem savulaik to visai sāpīgi un trağiski vajadzēja piedzīvot. Bet kāda situācija šajā jomā ir pašlaik? Vai kriminālpolitiskie līdzekḷi tiek izmantoti pietiekami, lai cilvēki dzīvotu droši un būtu aizsargāti no kriminālo draudu eskalācijas? Vai jaunie drošības apdraudējumi tiek apzināti? Vai tiek rasti instrumenti, lai tos nepiel̦autu un pārtrauktu? Vai noziedzības apkarošana un drošības nodrošināšana ir valsts pārvaldes sistēmas prioritāte?

Grāmatas lasītāji tiek iepazīstināti ar autora viedokli par to, vai Latvijā ir krimināltiesiskā politika un kā tā ietverta politiskās plānošanas dokumentos, turklāt izdevumā var gūt arī nelielu ieskatu krimināltiesiskās politikas veidošanas vēsturē.

Kipāne, A., un Vilks, A. (2016). Kriminālais sekss. [B.i.]. 434 lpp.

Grāmata veltīta seksuālās vardarbības kriminologisko aspektu analīzei. Seksuālā vardarbība vai kriminālais sekss ir būtisks indivīda apdraudējuma veids, kā arī l̦oti nopietna indivīda drošîbas un veselības aizsardzības problēma Latvijā un pasaulē.

Darbā atspoguḷoti seksuālās vardarbības kā sociālas un tiesiskas parādības kriminologiskie aspekti, apzinātas tās tendences, ieskicēti seksuālās vardarbības cēloṇi un veicinošie apstākḷi, veikta noziedznieka personības analīze, kā arī atspoguḷotas viktimolog̣iskās pieejas seksuālās vardarbības upuru izziñā.

Kriminologijas teorētiskās nostādnes un tās sistēma ir cieši saistīta ar citām sociālajām zinātnēm. Monogrāfijā ir plaši analizēti dažādi avoti un zinātniskā literatūra (kriminolog̣ijā, krimināltiesībās un psiholog̣ijā), juridiskā prakse un kriminālā statistika. Lasītāii tiek iepazīstināti ar interesantiem secinājumiem un ieteikumiem seksuālās vardarbības izpētes un novēršanas jomā.

Grāmata domāta praktizējošiem juristiem, kā arī juridisko mācību iestāžu akadēmiskajam personālam un studentiem. 
Pielikums. RSU Juridiskās fakultātes akadēmiskā personāla sagatavotās un izdotās monogrāfijas (2009-2019)

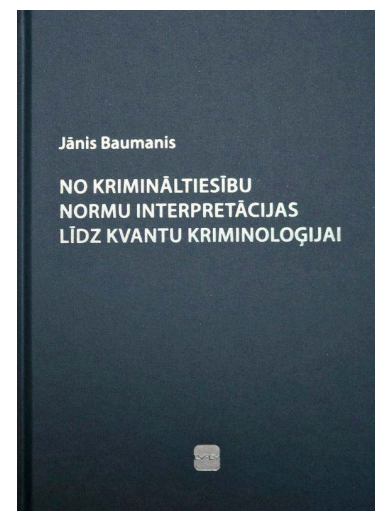

Baumanis, J. (2017). No krimināltiesību normu interpretācijas līdz kvantu kriminologijai.

Latvijas Vēstnesis. 264 lpp.

Monogrāfijā ietvertos rakstus vieno to piesaiste krimināltiesībām. Apkopojot dažādus krimināltiesisko institūtu interpretācijas variantus, grāmatas autors aplūko noziedzīgu nodarījumu, tā sastāva objektīvās un subjektīvās pazīmes un krimināltiesisko piespiedu līdzekḷu problemātiku. Viṇš ir iedziḷinājies ne vien kriminologijāa bet arī psihologijā, filologijā, daiḷliteratūrā un teologijā.

Darba filozofiskais aspekts orientēts uz kriminālatbildības jēgas meklējumiem. Autors lasītājiem vispirms piedāvā iespēju iepazìt krimināltiesību normu interpretācijas un noziedzīga nodarījuma vispārīgo raksturojumu, tad analizē noziedzīga nodarījuma objektīvās un subjektīvās pazīmes un, visbeidzot, atklāj krimināltiesisko piespiedu līdzekḷu politikas, zinātnes un prakses attīstību. Noziedzīga nodarījuma subjektīvo pazìmju kontekstā minētos aspektus Baumanis piedāvā dēvēt par kvantu kriminologiskajiem aspektiem. Kriminologijas kontekstā jēdziens "kvants" simbolizē temata dziḷumu un detalizētības augsto pakāpi - tā grāmatas ievadā skaidro autors. Kvanta jēdziena izmantošana viṇam ḷāvusi tēlaini aprakstìt dažus krimināltiesiskos institūtus, kas pētījumiem piešksir unikalitāti.

Monogrāfija ir nozīmīgs krimināltiesisko atziṇu avots, kas noder gan praktiḳiem, gan teorētiķiem. Tajā paustās atziṇas var izmantot tiklab likumdošanā un tiesu praksē, kā arī izglīî̉bā - grāmatas priekšvārdā uzsver Augstākās tiesas Senāta Krimināllietu departamenta priekšsēdētājs Pēteris Dzalbe.

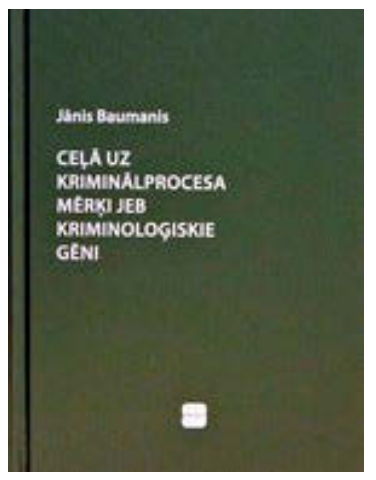

Baumanis, J. (2018). Cel̦ā uz kriminālprocesa mērḳi jeb kriminologiskie gēni.

Latvijas Vēstnesis. 276 lpp.

Kriminālprocesa tiesību tematikai veltītajā grāmatā autors tiesību institūtus analizē sasaistē ar praksi. Izgaismojot konkrētu tiesisku problemātiku, viņš ne vien piedāvā iespējamos variantus prakses uzlabošanai, bet arī pauž savu viedokli. Tādējādi grāmatā ietvertās atziṇas var būt nozīmīgas turpmākā tiesību normu jaunradē, jo autors piedāvā vairākus tiesību normu pilnveidošanas variantus.

Autors pievēršas gan kriminālprocesa tiesībām, gan arī kriminologiijai un krimināltiesībām, piedāvāto tematiku integrējot dažādās tiesību nozarēs. Tās visas tiek sasaistītas, par pamatu nemot noziedzīgu nodarījumu un izmantojot analog̣iju. Šāda pieeja piešḳir grāmatai unikālu stilu. Monogrāfijas struktūru autors pakārtojis kriminālprocesa norises secībai, virzoties no kriminālprocesa uzsākšanas uz tā pabeigšanu, īpašu uzmanību pievēršot noziedzīga nodarījuma cēloṇu un veicinošo apstākḷ noskaidrošanai.

Grāmata noder ikvienam krimināltiesību nozares praktiḳim, kā arī krimināltiesību studentiem. Arī likumdevēji to var izmantot likumprojektu izstrādes diskusijām. 